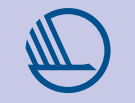

Nordiska ministerrådet

\title{
GRÄNSHINDERRÅDETS ÅRSRAPPORT 2017
} MED KOMMENTARER FRÅN DE NORDISKA REGERINGARNA UNDERLAG FÖR GRÄNSHINDERRÅDETS ARBETE 2017
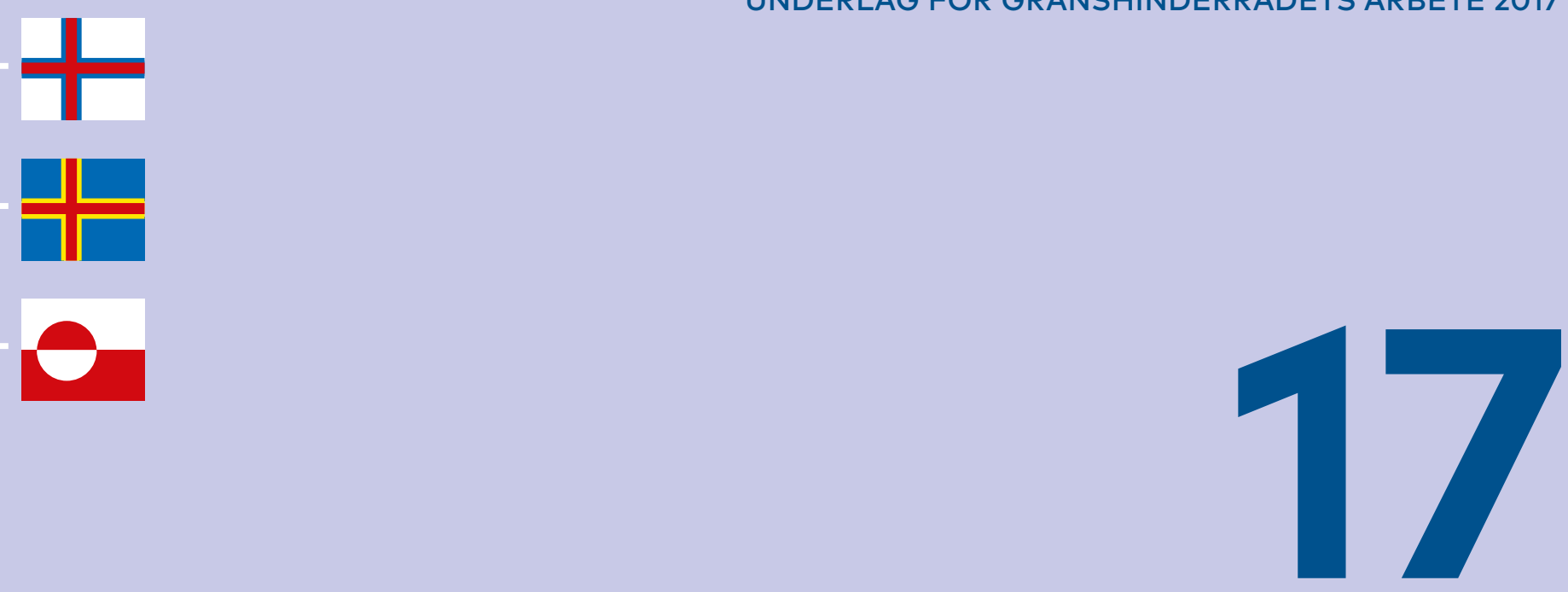

KÖPENHAMN DEN 15 JANUAR 2018 


\section{Gränshinderrådets årsrapport 2017}

Med kommentarer från de nordiska regeringarna - Underlag för gränshinderrådets arbete 2018

\section{ANP 2018:719}

ISBN 978-92-893-5373-1 (PRINT)

ISBN 978-92-893-5374-8 (PDF)

ISBN 978-92-893-5375-5 (EPUB)

http://dx.doi.org/10.6027/10.6027/ANP2018-719

(C) Nordiska ministerrådet 2018

Layout: Peter Daniel Olsen/Resonans Kommunikation

Tryck: Stibo Graphic

Printed in Denmark

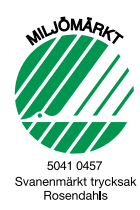

\section{Det nordiska samarbetet}

Det nordiska samarbetet är ett av världens mest omfattande regionala samarbeten. Det omfat-tar Danmark, Finland, Island, Norge och Sverige samt Färöarna, Grönland och Åland.

Det nordiska samarbetet är politiskt, ekonomiskt och kulturellt förankrat och en viktig del av europeiskt och internationellt samarbete. Den nordiska gemenskapen arbetar för ett starkt Norden i ett starkt Europa.

Det nordiska samarbetet vill styrka nordiska och regionala intressen och värderingar i en global omvärld. Gemensamma värderingar länderna emellan bidrar till att stärka Nordens ställning som en av världens mest innovativa och konkurrenskraftiga regioner.

\section{Nordiska ministerrådet}

Nordens Hus

Ved Stranden 18

DK-1061 København K

www.norden.org

Ladda ner nordiska publikationer: www.norden.org/nordpub 
(10) Nordiska ministerrådet

GRÄNSHINDERRÅDETS ÅRSRAPPORT 2017 MED KOMMENTARER FRÅN DE NORDISKA REGERINGARNA UNDERLAG FÖR GRÄNSHINDERRÅDETS ARBETE 2018

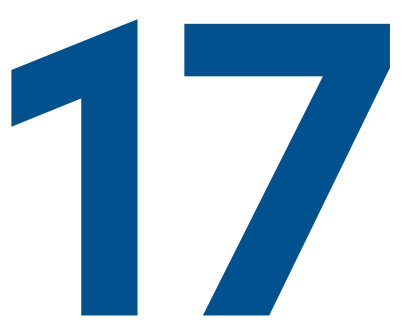




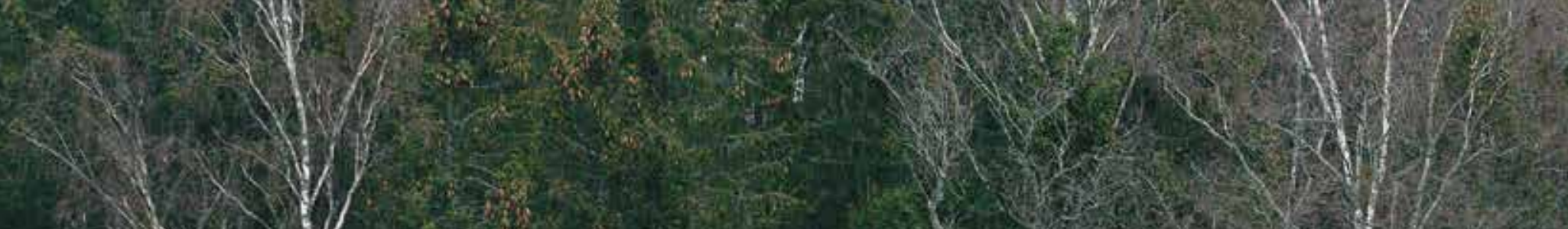
$\frac{(12)}{4}$

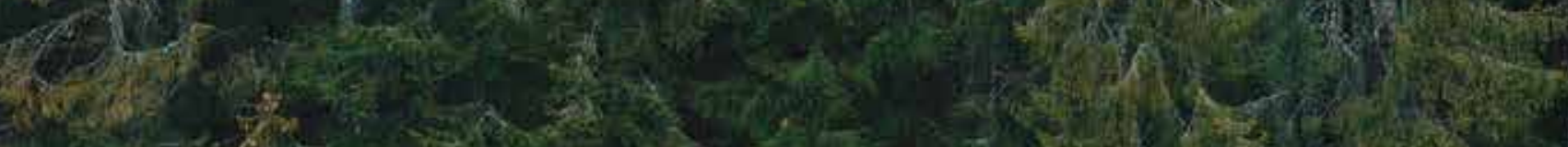
2. 3

2

$x+3$ 


\title{
Innehållsförteckning
}

\author{
7 Statsministerdeklaration \\ 9 Förord \\ 10 Gränshinderrådets medlemmar \\ 15 Organisering av Gränshinderrådets arbete \\ 17 Gränshinderrådets mål \\ 18 Innehållsförteckning med status \\ 21 Hinder på arbetsmarknadsområdet \\ 33 Hinder på utbildningsområdet \\ 43 Hinder på social- och hälsoområdet \\ 63 Hinder på skatteområdet \\ 75 Hinder på näringslivsområdet \\ 85 Övriga gränshinder \\ 104 Avklarade gränshinder under 2014-2017 \\ 106 Avklarade, inte lösta 2014-2017. Avskrivna av berörda departement \\ 110 Nordiska rådets Gränshindergrupp \\ 112 Dialogen med arbetsmarknadens parter \\ 114 Informationsarbetet \\ 120 Det förebyggande arbetet \\ 121 Mandat for Grænsehindringsrådet 2018-2021 \\ 125 Efterord
}





\title{
De nordiska statsministrarnas deklaration med anledning av den nya strategin och handlingsplanen för avlägsnande av gränshinder i Norden. Den nya strategin och handlingsplanen behandlades vid Nordiska rådets
} 65:e session i oktober 2013.

\author{
Norden som föregångare för gräns/öst samarbete i syfte att skapa \\ jobb och tillväxt.
}

Vi, statsministrar från Danmark, Finland, Island, Norge och Sverige, lagmanden från Färöarna, landsstyreformanden i Grönland samt lantrådet på Åland, är eniga om att arbetet med att bekämpa gränshinder i syfte att skapa jobb och tillväxt i Norden, är en av det nordiska samarbetets viktigaste utmaningar. Detta gäller inte minst vårt gemensamma behov av att hjälpa unga människor in på arbetsmarknaden.

Genom att skapa optimala förutsättningar för individer och företag att verka över gränserna i Norden stärker vi regionens globala konkurrenskraft.

En starkt prioriterad insats är därför arbetet med att aktivt avlägsna gränshinder. Gränshinder kostar, hämmar utveckling och tillväxt och ger färre valmöjligheter för den enskilde.

Gränshinderforum, som tillsattes av de nordiska statsministrarna år 2007, har på ett värdefullt sätt arbetat för att minska gränshinder i Norden. För ytterligare stärka och effektivisera gränshinderarbetet utvecklar vi nu organisationen till ett Gränshinderråd med en ny strategi- och handlingsplan, som kommer att träda i kraft den 1 januari 2014.
Detta innebär att:

- arbetet kommer att kopplas tätare till den politiska ledningen i Nordiska ministerrådet genom att ordförandelandet i Nordiska ministerrådet också kommer att vara ordförande i Gränshinderrådet.

- Nordiska ministerrådets generalsekreterare får en starkare roll i gränshinderarbetet för ministerrådet.

- Gränshinderrådets nationella representanter får ett tydligt uppdrag att samarbeta med de aktörer som kan bidra till att få gränshinder lösta för individer och företag i Norden. Detta samarbete omfattar bl.a. ländernas departement och myndigheter, parlamentariker och de gränsregionala informationstjänsterna.

Den nya formen för nordiskt gränshindersarbete kommer att bidra till ett effektivare arbete för att riva gränshinder och öka rörligheten i Norden.

För att uppnå detta bör vi ha som mål:

- att verka för en öppen och välfungerande gemensam arbetsmarknad

- att skapa bästa möjliga förutsättningar för nordiska företag att verka över gränserna i Norden

- att säkra, så långt det är möjligt, likartad genomförande av EU-rättslig lagstiftning i Norden genom en löpande dialog mellan de nordiska länderna

- att verka för att länderna samråder, när så behövs, när nya eller ändrade lagar och regler införs i syfte att undvika att nya gränshinder uppstår. 


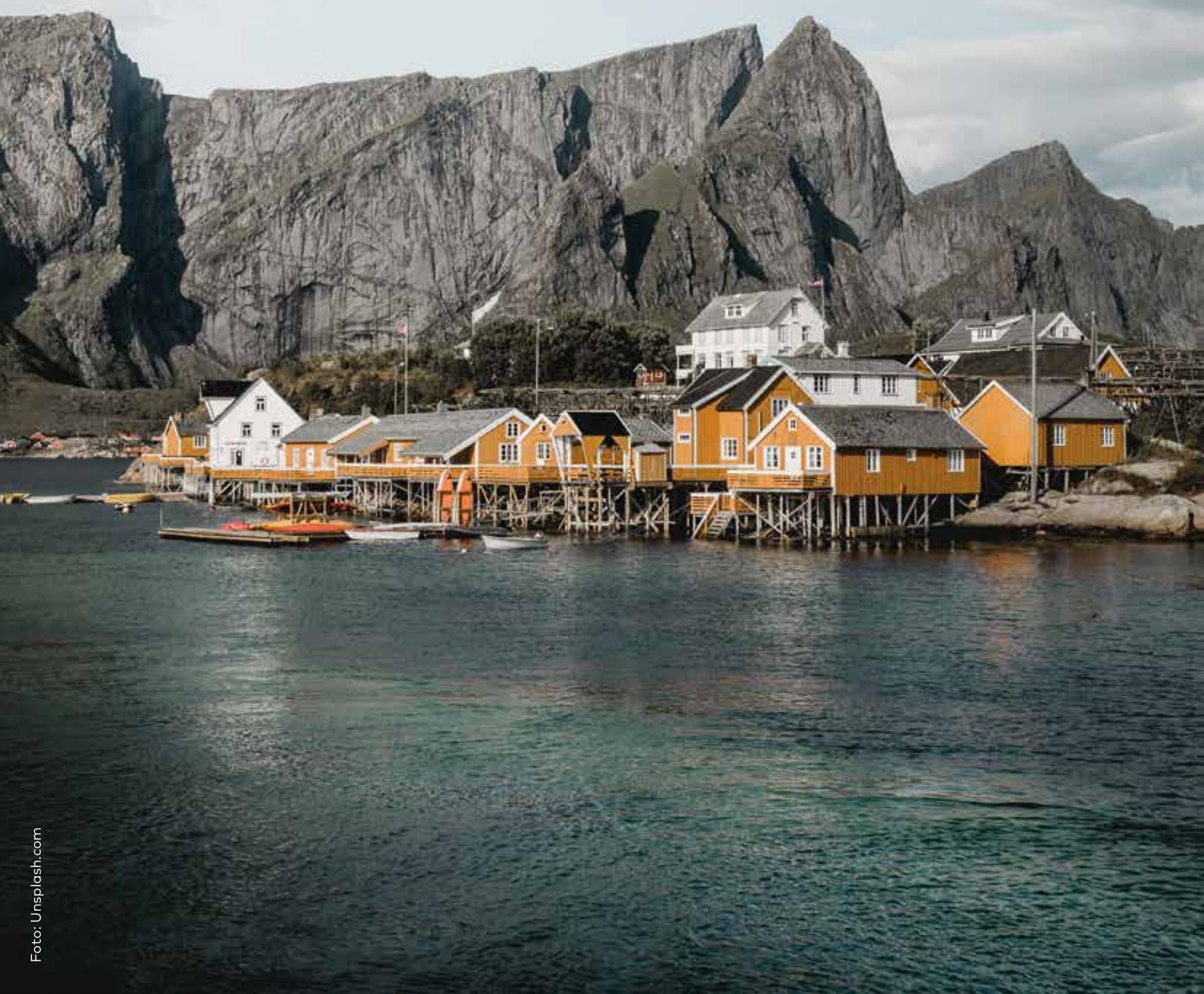




\section{Förord}

De nordiske statsministrene har satt målet; Norden skal være verdens mest integrerte region. Grensehinderrådet er ett av regjeringssjefenes verktøy. Vi har ambisjoner om å bidra til at Norden skal være så integrert at både næringslivet og enkeltmennesker ikke opplever at nasjonale grenser begrenser deres frie bevegelighet.

På den annen side kan ikke Grensehinderrådet oppheve en eneste grensehinder. Vi kan avdekke et hinder, etterspørre løsninger og påvirke departementene og regjeringene å løse opp for grensepasseringer uten hindringer. Ut fra det mandat stats- og samarbeidsministrene har gitt oss skulle vi gjerne sett større vilje og evne i flere departementer.

Grensehinderrådet arbeider ut fra ønsket om at store og byråkratiske hindringer innenfor blant annet skatt, avgifter og sosiale ordninger skal kunne fjernes, men det er bare de enkelte lands myndigheter som har verktøyet til slike løsninger. Vår erfaring er at det er lettest å løse mindre kompliserte grensehinder. Grensehinderrådet kan altså ikke lastes dersom noen mener vi burde oppnådd mer ambisiøse resultater.

I 2017 er Grensehinderrådet evaluert av en ekstern instans, og har fått karakteren bestått.

Evalueringen utført av Oxford Research viser at Grensehinderrådet har levert og levd opp til de ønskene og kravene man har stilt til Grensehinderrådet ut fra mandatet. De nordiske samarbeidsministrene besluttet i møtet sitt i Helsingfors 03.11.2017 å fornye og forsterke Grensehinderrådets mandat med ytterligere fire år.

Vårt arbeid forberedes gjennom de meldinger og erfaringer de regionale grensetjenestene og Hallo Norden bringer inn til Nordisk Ministerråds grensehinderdatabase. Kvalitetssikringen og innhenting av ytterligere bakgrunnsopplysninger har sekretariatet utviklet prosedyrer for. I så måte er Grensehinderrådet avhengig av juridisk og faglig bistand fra dyktige medarbeidere. Vi takker både dem og de entusiastiske ansatte som jobber $\mathrm{i}$ de regionale grensetjenestene.

De grensehinder vi prioriterer skal oppfylle målsettingen om den integrerte regionen, bærekraftig vekst og relevans for borgerne.

I 2017 har 8 prioriterte grensehindre blitt avklart, 6 har blitt løst av berørte ministre eller departementer og 2 har blitt avskrevet som ikke mulige å løse på det nåværende tidspunktet. I rapporten kan du lese om disse grensehindrene.

Grensehinderrådet har, utover et fokus på grensehindre for borgerne, også holdt nasjonale dialogmøter med arbeidsmarkedets parter i Norden. I møtene har det vært fokus på grensehindre som berører mobilitet og tilvekst i Norden sett fra et næringslivsperspektiv.

Det norske formannskapet i Nordisk ministerråd har i 2017 hatt overskriften "Norden i omstilling" og pekt på at det nordiske samarbeidet må styrke vår felles evne til å møte endringene. Grensehinderrådet er seg bevisst at vårt arbeid skal bidra til omstilling og konkurransekraft. Slik bidrar vi til å skape nye arbeidsplasser og styrke konkurransekraften. Begge deler er forutsetninger for fornyet vekst.

Grensehinderrådets medlemmer takker for den tillit Samarbeidsministrene viser oss. Vi anbefaler statsrådene og embetsverkene også i tiden fremover å finne løsninger på grensehinder som er til hinder for oppfyllelsen av den felles nordiske viljen om å styrke det nordiske næringslivets globale konkurransekraft, og hjelpe unge arbeidssøkende inn i arbeidslivet. 


\section{Gränshinderrådets medlemmar}

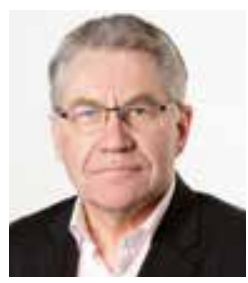

\section{Svein Ludvigsen · Norge • Ordförande 2017}

Grensehinderrådets arbeid handler om enkeltmenneskers og bedrifters muligheter til å oppfylle de nordiske statsministres ambisjon om at Norden skal være verdens best integrerte region. Det målet kan bare oppnås dersom departementene i de enkelte land og selvstyreområdet viser evne og vilje til å endre lovgivning eller praksis i konkrete saker.

Jeg er tilfreds med at regjeringen i Norge har satt grensehinder høyt på sin dagsorden, og at embetsverket både kan og vil finne løsninger der det er mulig. Selv er jeg utålmodig og vil mer. Derfor setter jeg stor pris på det gode samarbeidet med både departementene og Stortingets delegasjon til Nordisk Råd.

Jeg takker for samarbeidet og tilliten jeg er vist ved å få representere Norge i Grensehinderrådet.

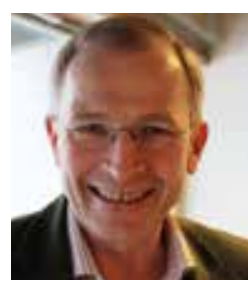

\section{Risto E.J. Penttilä • Finland}

De nordiska länderna har redan under många decennier varit föregångare när det gäller långt gående integration. Jag vill försäkra mig om att samarbetet består och fördjupas. För att så skall ske bör gränshinderrådet fortsätta sina ansträngningar för att avskaffa olika former av hinder som försvårar medborgarnas rörlighet och företagens verksamhet. Det handlar om att söka praktiska lösningar för att stöda statsministrarnas strävan att befästa Nordens ställning som världens mest integrerade område.

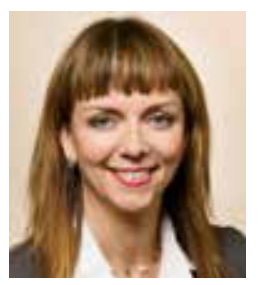

\section{Siv Fridleifsdottir - Island}

Vi lever i tid där människor inom Norden reser mycket mer över nationsgränserna än tidigare. Inom Norden gör vi affärer och arbetar tvärs över gränserna, studerar i ett annat nordiskt land eller flyttar av någon annan orsak. Tidigare accepterades gränshinder som något naturligt, men i en allt mer gränslös värld finner man sig inte i att gränserna utgör hinder. Vi arbetar mot gränshinder och tror att många områden kan förbättras för att öka tillväxten, även om vi samtidigt är medvetna om att Norden inte kan bli helt gränslöst. Statsministrarna har nyligen gett oss i uppgift att utveckla samarbetet med arbetsmarknadens parter för att ta bort gränshinder och öka tillväxten. 


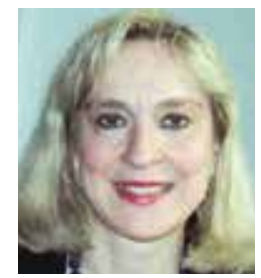

\section{Eva Tarselius Hallgren · Sverige}

Vår vision är att så många hinder som möjligt som påverkar rörligheten mellan de nordiska länderna ska kunna elimineras. Nordiska invånare ska kunna bo i ett land och arbeta eller studera i ett annat och på samma sätt ska företag kunna verka över nationsgränserna utan att hamna i kläm på grund av nationella regelsystem eller olika regeltillämpning. Det ska vara lätt att få korrekt information om ländernas olika regelverk. Det är viktigt att Gränshinderrådet fortsatt arbetar tätt tillsammans med andra gränshinderaktörer så som ansvariga departement, myndigheter, gränsregionala informationstjänster, arbetsmarknadens parter m.fl. för att finna lösningar på så många gränshinder som möjligt. Det nya mandatet från samarbetsministrarna innebär ökade befogenheter för rådet och höjda krav på antalet gränshinder som ska behandlas.

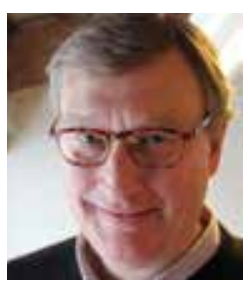

\section{Kim Andersen - Danmark}

Mobilitet for nordiske borgere og virksomheder er helt centralt for vækst, udvikling og udveksling i Norden. Grænsehindringsrådet yder gennem sit arbejde et vigtigt bidrag til at fjerne konkrete grænsehindringer. Det er helt centralt, at alle relevante aktører i nordisk og nationalt regi fremadrettet arbejder med både at forebygge og at fjerne utilsigtede grænsehindringer, så vi kan leve op til visionen om Norden som den mest integrerede region. Erhvervslivets parter kan bidrage yderligere med helt konkret at pege på, hvori problemer består og gerne også hvordan de eventuelt kan løses.

Kim Andersen fratrådte som medlem den 1. september 2017, hvor han tiltrådte som dansk Generalkonsul i Flensborg. Morten Skovgaard Hansen har deltaget siden den 1. september 2017.

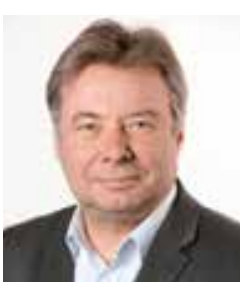

\section{Gunnar Westerholm • Åland}

Mina förväntningar på Gränshinderrådet är att även det arbete som redan utförts följs upp och leder till resultat. Förhoppningen är också att Gränshinderrådet kan upprätthålla en auktoritet mot ministerier och myndigheter så att gränshinderarbetet prioriteras på alla nivåer. Informationens tillgänglighet måste lyftas fram som en faktor för att minska antalet drabbade. Ett gränshinder är, oavsett hur många som drabbas, ett hinder för mycket. 


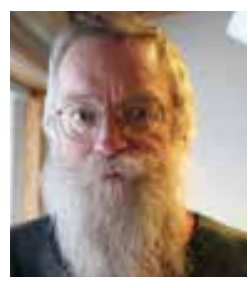

\section{Jørgen S. Søndergaard, Grönland}

Ikke tilsigtede grænsehindringer bør kunne ryddes af vejen, når landenes forvaltninger bliver gjort opmærksom på dem. Grænsehindringsrådets opgave er, at være katalysator for en løsning til gavn for nordiske borgeres og virksomheders frie bevægelse og forretninger i Norden.

Bevidste grænsehindringer kan bringes frem til politisk prøvning af, om de fortsat opfylder den funktion, som de var tiltænkt. Herefter bør mulighederne for afskaffelse undersøges.

Erfaringerne viser, at det er særligt vigtigt, at repræsentanterne fra Åland, Færøerne og Grønland er opmærksom på de situationer, hvor en sag forlader dagsordenen i Nordisk Ministerråd. En sag kan nogle gange behandles effektivt i nordiske uformelle netværk, som eksisterer mellem myndigheder i de 5 lande, der har underskrevet Helsingforsaftalerne.

Det viser den gode nordiske tradition for pragmatiske løsninger. Men samtidig skal man være opmærksom på, at det kan betyde, at muligheden for at deltage i arbejdet med sagens løsning forsvinder for de 3 lande, der har selvstyreordninger.

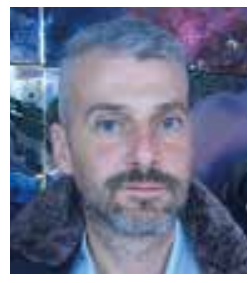

\section{John Johannessen • Färöarna}

Jeg tror på et stærkt nordisk fællesskab og en nordisk region med fri bevægelighed for de nordiske borgere. Som nyt medlem i Grænsehindringsrådet ser jeg det som en spændende og inspirerende opgave at være med til at identificere og fjerne utilsigtede grænsehindringer mellem landende.

Efter min opfattelse er det også en vigtig opgave for Grænsehindringsrådet at være med til at forebygge, at der opstår nye grænsehindringer. Derfor er det vigtigt for os medlemmer af rådet at være aktive og være på vagt i forbindelse med udviklingen $i$ vores reskeptive lande.

En potentiel stor grænsehindring kan let opstå inden for den digitale udvikling. Her har man set, at hvert enkelt land udvikler egne sikre digitale løsninger til kommunikation med borgerne i de respektive lande. Her er det vigtigt at tænke problemstillingen ind, at der kan opstå en ret væsentlig grænsehindring, om man ikke finder ud af, hvordan de offetlige digitale platforme kan virke på tværs af de nordiske grænser.

Som nyt medlem i rådet, glæder jeg mig til at få sat mig nærmere ind i sagerne og et fortsat aktivt arbejde i rådet. 


\section{Dagfinn Høybråten - Nordiska ministerrådet}

Grensehindringsrådet har en unik sammensetning av folk med tung politisk, faglig og administrativ bakgrunn. Jeg har stor tro på at vi sammen kan løse flere grensehindringer i samspill med dem som lager lover og regler i de nordiske land. Som ledd i Moderniseringsreformen Nytt Norden arbeides det nå mer målrettet med EU-saker i fagministerrådene. Det gir økt felles nordisk aktivitet både i utforming og implementering av regelverk som har betydning for mobiliteten mellom landene. En stor utfordring framover blir å sikre at den nye situasjon med økt migrasjon ikke bidrar til en generell svekkelse av Norden som en sammenhengende region, men at vi fortsatt kan tenke innovativt sammen om løsninger som møter fremtidens behov.

Et grenseløst Norden der innbyggerne behandles mest mulig likt og kan bevege seg fritt over landegrensene har alltid vært en bærende ide for det nordiske samarbeidet.

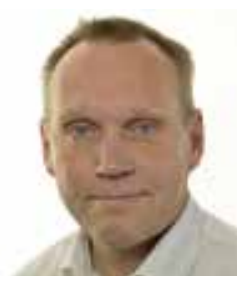

\section{Pyry Niemi • Nordiska rådet}

Från Nordiska rådets sida är arbetet med att undanröja gränshinder mellan de nordiska länderna något som står allra högst på dagordningen. För att matcha det arbete som görs i Gränshinderrådet, har Nordiska rådet etablerat en särskild grupp, Gränshindergruppen. I Gränshindergruppen koordinerar och förbereder vi de gränshinderfrågor som Nordiska rådet arbetar med i de olika utskotten. Under 2017 har Nordiska rådet/Gränshindergruppen tagit flera initiativ, bland annat för att motverka uppkomsten av nya gränshinder, men även för att sätta ytterligare press på de nordiska regeringarna. Inför 2018 höjer Nordiska rådet ambitionen ytterligare. Jag har höga förväntningar om att såväl Gränshinderrådet som Gränshindergruppen/Nordiska rådet kommer att bidra till att lösa många fler hinder under den kommande mandatperioden, men också motverka uppkomsten av nya hinder i samband med ny nationell lagstiftning och implementering av EU-direktiv. 


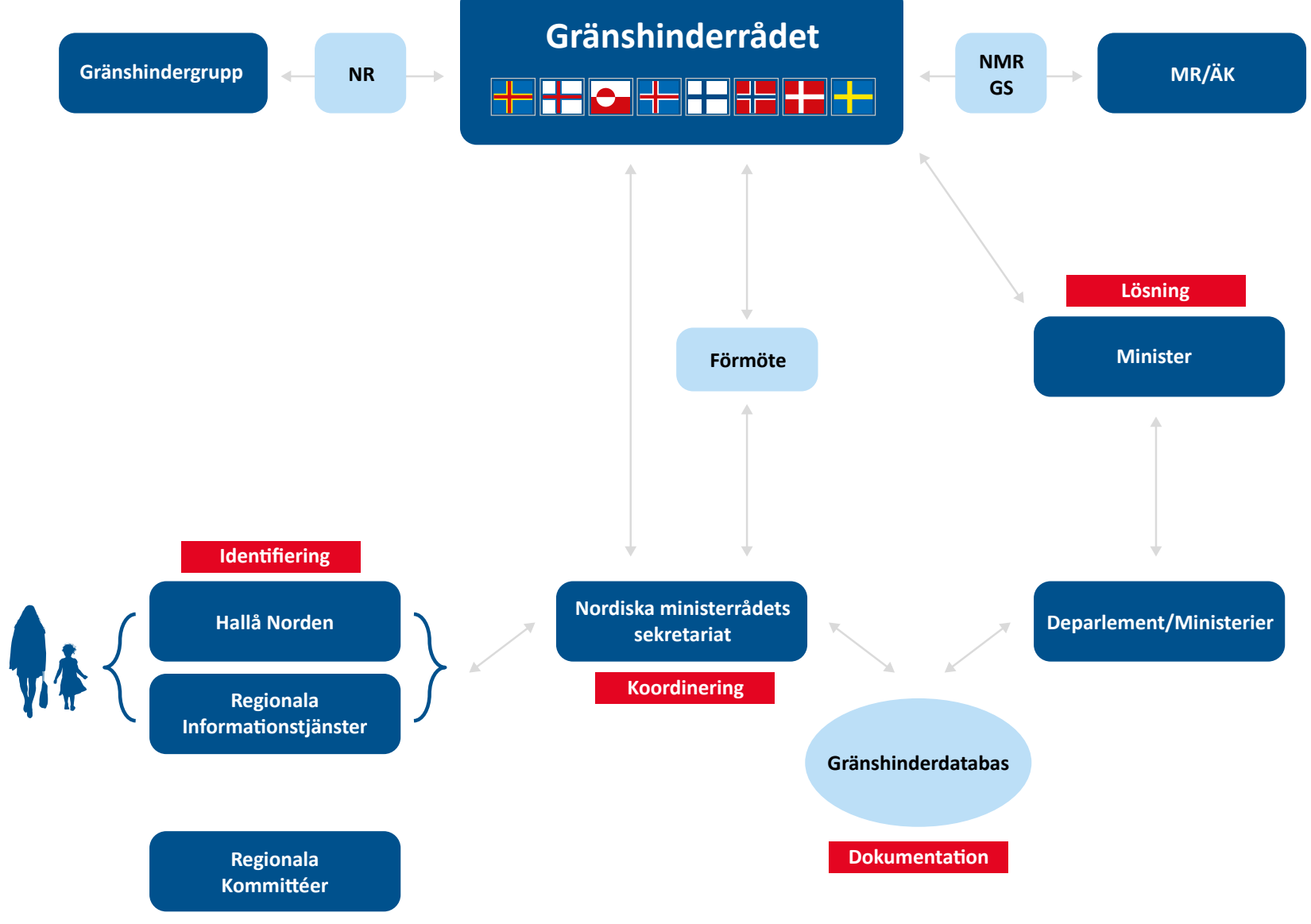




\section{Organisering av Gränshinderrådets arbete}

Det är av stor betydelse att Gränshinderrådets arbete, både regionalt och nationellt, kopplas till berört nordiskt ministerråd och till berörda nationella departement och parlament. Detta för att skapa transparens och delaktighet i det nordiska gränshinderarbetet mellan medborgarnas och företagens identifierade gränshinder i hela Norden.

Illustrationen ger en bild av hur Gränshinderrådets arbete är organiserat.

\section{Identifiering}

Gränshinder identifieras där medborgare och företag söker information om att förflytta sig över de nordiska gränserna. För att möta medborgarnas informationsbehov har man i Norden utvecklat de regionala informationstjänsterna Øresunddirekt, Grensetjänsten Sverige/Norge och Nordkalottens Gränstjänst. Därutöver finns även den nordiska informationstjänsten Hallå Norden som är placerad i de nordiska huvudstäderna. Informationstjänsterna identifierar hinder och inrapporterar dessa till Nordiska ministerrådets sekretariat samt förmedlar information via webb, e-post, telefon, personlig betjäning samt vid informationsträffar för privatpersoner och företag.

\section{Koordinering}

Sekretariatet ansvarar för att koordinera Gränshinderrådets arbete. Sekretariatet koordinerar även Gränshinderrådets arbete med det gränshinderarbete som bedrivs i Nordiska ministerrådets sekretariat under respektive ministerråd. Sekretariatet samordnar också informationstjänsternas verksamhet utifrån en gemensam handlingsplan som ska öka samarbetet och effektivisera gränshinder- och informationsarbetet.

\section{Dokumentation}

Samtliga identifierade gränshinder dokumenteras i gränshinderdatabasen. Berörda departement kvalitetssäkrar innehållet i databasen.

\section{Prioritering av gränshinder}

För att skapa långsiktighet och struktur i gränshinderarbetet väljer varje medlem i Gränshinderrådet ut 3-5 gränshinder som prioriteras i Gränshinderrådets arbete. Urvalet görs utifrån de hinder som är registrerade i Gränshinderdatabasen. Medlemmarna kan välja att prioritera vissa hinder gemensamt.

Medlemmarna kan även driva gränshinder som identifieras som akuta och som är av särskilt stort intresse att lösa under året.

De nationella medlemmarna uppvaktar berörda departement och ministrar tills besked lämnas om hindret kan lösas eller om departementet beslutar att inte gå vidare med att lösa hindret. Då ett hinder avklaras på detta sätt prioriterar Gränshinderrådets medlem ett nytt hinder att arbeta med. I Gränshinderrådets årsrapport redovisas varje år en statusuppdatering från Gränshinderrådets medlemmar och berörda departement. På så sätt kan man följa processen kring de prioriterade hindren.

Nordiska ministerrådets representant i Gränshinderrådet koordinerar Gränshinderrådets arbete med det gränshinderarbete som bedrivs i de berörda ministerråden. Nordiska rådets representant i Gränshinderrådet koordinerar Gränshinderrådets arbete med det gränshinderarbete som bedrivs i Nordiska rådet vars medlemmar kan lyfta de prioriterade gränshindren i sina nationella parlament.

\section{Lösning}

Det är bara beslutsfattare i de nordiska länderna, Färöarna, Grönland och Åland som kan finna en lösning på de identifierade hindren. Gränshinderrådet kan däremot verka för att lösa gränshinder som hämmar mobilitet och tillväxt för medborgare och företag i Norden genom att ta fram en tydlig problembeskrivning, förslag till lösning, samt, i den mån det är möjligt, kostnadsanalyser. Gränshinderrådet arbetar i enlighet med det uppdrag rådet har fått av de nordiska statsministrarna och lägger därför stor vikt vid samarbetet och den öppna dialogen med de departement och myndigheter som berörs av gränshindren. 


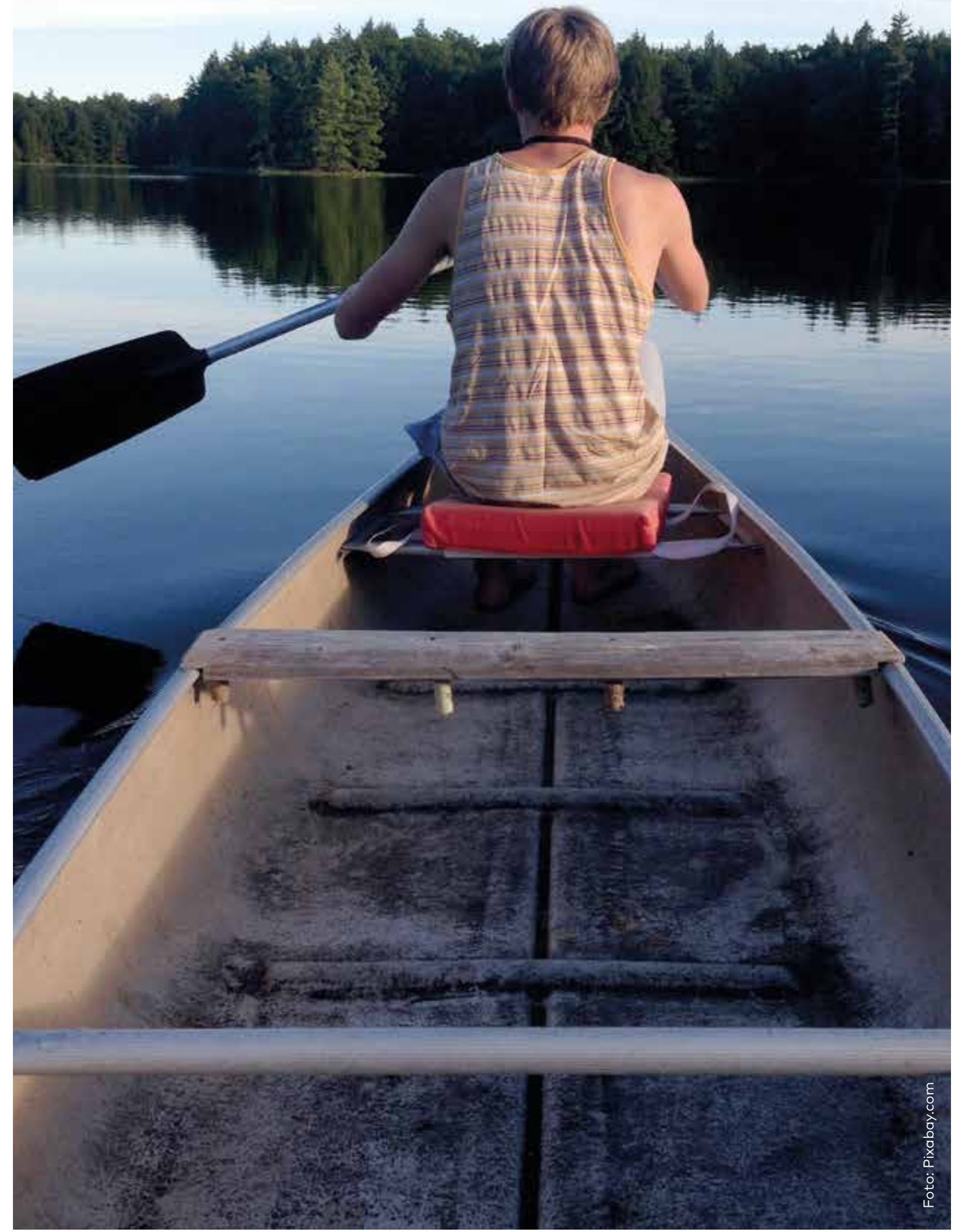




\section{Gränshinderrådets mål}

Gränshinderrådet prioriterar gränshinder som uppkommer inom arbetsmarknads, social- och utbildningsområdet och som utgörs av lagar, offentliga regler eller praxis som hämmar individers mobilitet eller företags möjligheter att verka över gränserna i Norden.

Gränshinderrådet arbetar med de gränshinder som identifieras på gräsrotsnivå, det vill säga av Hallå Norden, Grensetjänsten Sverige-Norge, Øresunddirekt och Nordkalottens Gränstjänst.

Gränshinderrådets målsättning är att 5-10 nordiska gränshinder avskaffas varje år som resultat av Gränshinderrådets arbete.

\section{Prioriterade gränshinder}

Gränshinderrådets medlemmar har graderat arbetet med sina prioriterade hinder enligt en färgskala med fyra nivåer.

Blått betyder att ett slutligt svar har kommit från berörda departement. Av rubriken framgår om hindret faktiskt blivit löst eller om länderna beslutat att avskriva hindret och inte arbetar vidare för att hitta en lösning.

Grönt innebär att arbetet följer den process som respektive medlem satt upp för att få ett slutligt svar på huruvida hindret kommer att lösas eller inte.

Gult betyder det pågår någon form av arbete med hindret vid berörda departement.

Rött innebär att hindret för närvarande inte är prioriterat vid berörda departement eller myndigheter.
Årsrapporten 2017 innehåller information om status för de hinder som har prioriterats av Gränshinderrådets medlemmar.

Det är viktigt att notera att den status som anges för hinder som inte är avklarade kan ha ändrats sedan rapporten trycktes. Det bör också noteras att de nordiska ländernas regeringar kan göra en annan bedömning av hindret än Gränshinderrådets medlemmar.

\section{Definition av gränshinder}

I det nordiska gränshindersamarbetet är gränshinder "lagar, offentliga regler eller praxis som hämmar individers mobilitet eller företags möjligheter att verka över gränserna i Norden". Att olika ersättningsnivåer och skatter förekommer i de nordiska länderna är inte gränshinder. Däremot betraktas det som ett gränshinder om en person på grund av sin mobilitet får sämre villkor än andra personer i en jämförbar situation, såväl i bosättningslandet som i arbetslandet.

För att underlätta identifiering, inrapportering och kvalitetssäkring av gränshinder utarbetade Gränshinderrådets sekretariat under 2017 en checklista baserad på definitionen av ett gränshinder i Gränshinderrådets mandat, med en beskrivning av ett antal kriterier som en konkret problemställning ska uppfylla för att kunna kvalificeras som ett gränshinder.

\section{Om beräkningarna}

Vid beräkningen av kostnaderna i specifika gränshinder har vi så långt det har varit möjligt använt oss av befintlig statistik. I de fall ingen aktuell statistik har funnits till hands har vi gjort uppskattningar utgående från äldre statistiska uppgifter. I enskilda fall har vi varit tvungna att göra antaganden för att kunna illustrera kostnaderna. I sådana fall nämns detta särskilt i samband med beräkningarna. 


\section{Innehållsförteckning med status}

m.

Hinder på arbetsmarknadsområdet

Sida Status Prioriterat av

Anmälan till fel A-kassa kan medföra förlorad rätt till ersättning

22

SE

Rätt till tjänstledighet för politiskt uppdrag från arbete i annat nordiskt land

24

Krav på att omfattas av olika länders arbetslöshetsförsäkring utan

26

SE/DK

avbrott för att inte riskera lägre arbetslöshetsersättning

Åldersgräns för inträde i en svensk arbetslöshetskassa

28

SE

Rätt till inkomstrelaterad arbetslöshetsersättning i Sverige efter

arbeidsavklaringspenger från Norge

Hinder på utbildningsområdet

Sida

EU:s mobilitetsprogram

Erkännande av yrkeskvalifikationer

Begränsade möjligheter för svenska läkare att genomföra sin allmäntjänstgöring på Åland

Ansökning till norsk gymnasieutbildning

Hinder på social- och hälsoområdet

Ersättning för patientresa mellan Norge och Finland/Sverige

Finska fyramånadersregeln

Flytt för institutionaliserade personer

Olika krav på märkning av läkemedel och språk för bipacksedel

Man kan inte få närståendepenning om inte både vårdare och den sjüke är försäkrade i Sverige

Färdtjänst för funktionshindrade

Ledarhund vid resa

Personlig assistent vid flytt

Flytt med handikappfordon

Rätt till arbetslöshetsersättning efter permittering och uppsägning efter arbete i Norge
44

46

48

50

53

54

56

58

59

60
Sida Status Prioriterat av

SE

NMR

38

SE/AX

40

NO

$4 \quad \mathrm{FI} / \mathrm{NO} / \mathrm{SE}$

$6 \mathrm{FI}$

8 DK

50

○

IS/GL/FO

SE/AX

5

0

NO

56

NO/IS

NO

59

NO

FI
DKO
NO
NO IS
NO
FI




\begin{tabular}{|c|c|c|c|}
\hline Hinder på skatteområdet & Sida & Status & Prioriterat av \\
\hline Midlertidig import af heste mellem Norge og Sverige & 64 & ○ & NO/SE \\
\hline Norsk intern skattepraxis försvårar utförande av uppdrag i byggbranschen & 68 & - & NO/DK \\
\hline Värdetransport över gränsen & 71 & ○ & $\mathrm{FI}$ \\
\hline Tull och deposition i samband med överförsel av varor & 72 & - & $\mathrm{FI}$ \\
\hline Hinder på näringslivsområdet & Sida & Status & Prioriterat av \\
\hline Mobil livsmedelslokal som första ankomstplats i Finland & 76 & ○ & $\mathrm{FI}$ \\
\hline Import af norske lakseyngel til Sverige & 77 & ○ & SE \\
\hline Färöiska färdskrivarkort & 78 & ○ & $\mathrm{FO}$ \\
\hline Olika byggbestämmelser & 80 & ○ & $\mathrm{FI} / \mathrm{AX} / \mathrm{DK}$ \\
\hline $\begin{array}{l}\text { Brist på samlad information för små och medelstora företag } \\
\text { om att bedriva verksamhet i andra nordiska länder }\end{array}$ & 82 & ○ & $\mathrm{FI} / \mathrm{NMR}$ \\
\hline Övriga gränshinder & Sida & Status & Prioriterat av \\
\hline Samordningsnummer till utländska fritidshusägare i Sverige & 86 & ○ & SE \\
\hline Erkännande av färöiska körkort & 88 & ? & $\mathrm{FO}$ \\
\hline Erkännande av Grönländska körkort & 90 & ○ & GL \\
\hline $\begin{array}{l}\text { Digitala verktyg för att kommunicera med det offentliga fungerar } \\
\text { inte över de nordiska gränserna }\end{array}$ & 92 & 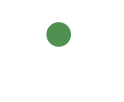 & SE/FI/FO \\
\hline Erkännande av föräldraskap för familjer med samkönade föräldrar & 94 & - & IS \\
\hline Norska regler för helikoptertrafik försvårar underhåll av renstängsel i Norge & 96 & ○ & $\mathrm{NO} / \mathrm{SE}$ \\
\hline Norska tullregler försvårar underhåll av renstängsel i Norge & 98 & ○ & NO/SE \\
\hline Dokumentationskrav för folkbokföring i Norge & 100 & - & NO \\
\hline Krav på utbyte av utländska körkort i Danmark & 102 & ○ & DK \\
\hline
\end{tabular}


gese

26

4

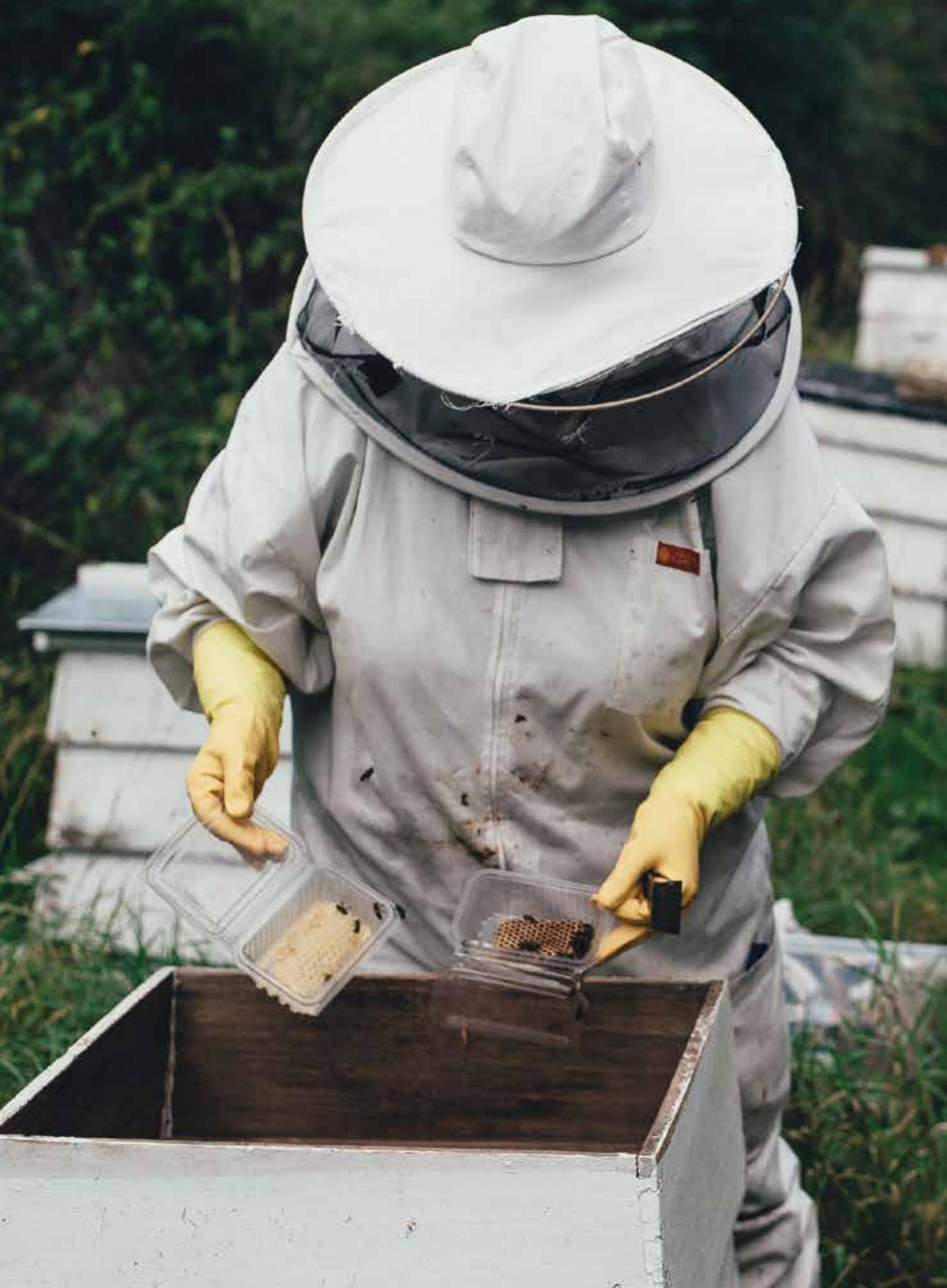




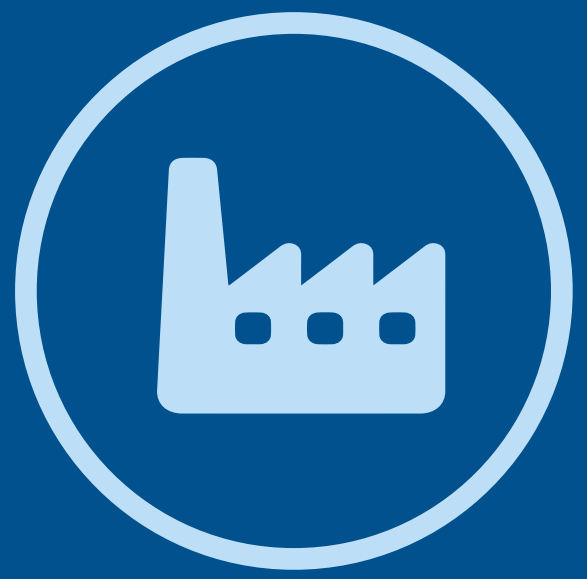

arbetsmarknadsområdet 


\title{
Anmälan till fel A-kassa kan medföra förlorad rått till ersåttning
}

\author{
Personer som blir arbetslösa kan förlora rätten till inkomstrelaterad \\ ersättning om de ansöker om medlemskap i fel a-kassa. Hindret kan drabba \\ både gränsarbetare och personer som bott och arbetat i Sverige.
}

Ett prioriterat gränshinder av Eva Tarselius Hallgren, Sverige.

Hindret kan lösas av Arbetsmarknadsdepartementet i Sverige.

Prioriterat av Gränshinderrådet sedan 2014.

\begin{abstract}
Bakgrund
För en gränsarbetare bosatt i Sverige som arbetar i Danmark gäller arbetslandets lagstiftning avseende den sociala tryggheten under tiden för arbete. Om personen blir helt arbetslös gäller istället bosättningslandets lagstiftning. För att erhålla inkomstrelaterad arbetslöshetsersättning från den svenska arbetslöshetsförsäkringen krävs enligt praxis medlemskap i svensk arbetslöshetskassa under tolv sammanhängande månader. Personen kan tillgodoräkna sig försäkringsperioder från tiden i Danmark som då likställs med medlemstid vid prövning av medlemsvillkoret.
\end{abstract}

Problem kan uppstå vid övergången från arbetslandets arbetslöshetsförsäkring till bosättningslandets arbetslöshetsförsäkring. Om en gränsarbetare eller annan person återvänder till Sverige efter arbete inom EU/EES måste han eller hon ansöka om medlemskap i en svensk arbetslöshetskassa omedelbart i samband med övergången mellan länderna. Enligt Inspektionen för arbetslöshetsförsäkringens föreskrift (IAFFS 2016:2) ska inträde begäras i den arbetslöshetskassa vars verksamhetsområde närmast motsvarar den sysselsättning han eller hon hade i arbetslandet. Om personen inte ansöker direkt kan ett avbrott i den pågående perioden uppkomma. Det är avbrottet i medlemskapet som är orsaken till att personen förlorar rätten till inkomstrelaterad arbetslöshetsersättning, inte att anmälan gjorts till fel a-kassa.
Det händer att gränsarbetaren ansöker om inträde i "fel" svensk a-kassa. Ofta vill man gå tillbaka till sin gamla a-kassa, men om man har arbetat i en annan bransch i utlandet är det inte möjligt att få inträde som gränsarbetare i den gamla a-kassan. Skickas inträdesansökan till fel a-kassa och den a-kassan hänvisar personen till en annan a-kassa, får den sökande inte ta med sig datumet för den ursprungliga inträdesansökan när inträde beviljas till den rätta a-kassan. Istället gäller ansökningsdatumet till den rätta a-kassan vilket kan få till följd att det uppstår ett glapp i försäkringsperioden. Detta kan i sin tur medföra att den sökande mister rätten till inkomstrelaterad ersättning och gränsarbetaren kan då enbart få ersättning enligt grundförsäkringen.

Hindret kan även uppkomma för personer som bor och arbetar i Sverige och måste byta arbetslöshetskassa med anledning av nytt arbete.

\section{Vem påverkas}

Gränspendlare bosatta i Sverige som nyligen blivit helt arbetslösa och söker arbetslöshetsersättning $i$ Sverige. Även personer som bott och arbetat i Sverige kan drabbas av ett avbrott vid byte av medlemskap från en a-kassa till en annan ifall det uppstår ett uppehåll i medlemskapet.

\section{Ekonomiska konsekvenser}

Johan bor i Sverige och arbetar i Danmark, har en lön på 30000 DKK i månaden och betalar varje 
månad in 443 DKK till sin danska a-kassa. Johan blir helt arbetslös och ska då anmäla sig till den svenska a-kassan. Tyvärr anmäler han sig till fel a-kassa i Sverige. När Johan anmäler sig till rätt a-kassa kommer han att kunna bli medlem. Om det har uppstått ett glapp i försäkringsperioden kommer Johan inte att få ersättning från inkomstbortfallsförsäkringen. Det betyder att Johan inte kan få den maximala a-kassa på 20020 SEK som han är berättigad till utan endast en grundersättning på 8030 SEK före och ca 6200 SEK efter skatt. Han går således miste om 11990 SEK per månad.

\section{Förslag till lösning}

Inför fyraveckorsregel för personer som ansöker om medlemskap i svensk a-kassa. Det betyder att man ger både den som ansöker om medlemskap och a-kassorna möjlighet att under dessa fyra veckor finna rätt a-kassa åt den arbetssökande utan att personen ifråga förlorar sitt sammanhängande medlemskap och går miste om möjligheten att få en inkomstrelaterad arbetslöshetsersättning.

\section{Gränshinderrådets arbete med frågan/ kommentarer från berörda regeringar}

Arbetsmarknadsdepartementet, Sverige:

Det är avbrottet i försäkring-/medlemsvillkoret som, i sig, är orsaken till att personen förlorar rätten till ersättning, inte att anmälan gjorts till fel a-kassa. Hindret har koppling till ett annat gränshinder "Krav på att omfattas av olika länders arbetslöshetsförsäk- ring utan avbrott för att inte riskera lägre arbetslöshetsersättning".

Att personer anmäler sig till fel a-kassa bör kunna avhjälpas genom att de får tillgång till både rätt och lättillgänglig information.

Det pågår en intern översyn av arbetslöshetsförsäkringen vid Arbetsmarknadsdepartementet i Sverige som bland annat omfattat frågor som rör avbrott i medlemskapet och vissa andra frågor som tidigare utretts av den parlamentariska socialförsäkringsutredningen. En departementsskrivelse remitterades i december 2016 och regeringen beslutade om en proposition till riksdagen i november 2017.

I propositionen föreslås att det ska framgå tydligt av lagen att rätten till inkomstrelaterad ersättning förutsätter medlemskap under minst tolv sammanhängande månader samt att regeringen eller den myndighet som regeringen bestämmer ska kunna meddela föreskrifter om vissa avbrott i medlemskapet som arbetslöshetskassan ska bortse från när medlemsvillkoret prövas. De nya reglerna föreslås träda i kraft under 2018.

Läs mer i Gränshinderdatabasen, granshinder.norden.org, gränshinder nr: 14-150. 


\title{
Rätt till tjänstledighet för politiskt upp- drag från arbete i annat nordiskt land
}

\author{
Den som bor $i$ ett nordiskt land och arbetar $i$ ett annat har inte rätt \\ till tjänstledighet för politiska uppdrag i bosättningslandet. Detta kan \\ vara ett hinder för att ta politiska uppdrag.
}

Ett prioriterat hinder av Eva Tarselius Hallgren Sverige och Kim Andersen, Danmark.

Hindret ingår i avtalet från 2013 mellan den danska regeringen och samtliga partier i det danska

Folketinget om att avlägsna gränshinder i Norden.

Prioriterat av Gränshinderrådet sedan 2014.

\begin{abstract}
Bakgrund
I de nordiska länderna finns regler om att förtroendevalda har rätt att få tjänstledigt från arbetet för att fullgöra politiskt uppdrag som de har valts till. Denna rätt gäller endast om personen bor, arbetar och utför politiska uppdrag i samma land. En gränsarbetare som blir förtroendevald i sitt bosättningsland har således inte motsvarande rätt till tjänstledighet $i$ sitt arbetsland för att utföra sitt politiska uppdrag i bosättningslandet.
\end{abstract}

Företrädare för Sverige, Danmark, Norge och Finland har under koordinering av Nordiska ministerrådets gränshinderrådssekretariat undersökt förutsättningarna för tjänstledighet för politiskt uppdrag i annat nordiskt land.

På det nordiska informella kommunministermötet i Oslo den 14 augusti 2014 skrev deltagarna under en deklaration om att man vill verka för att underlätta för förtroendevaldas ledighet i Norden.

En utredning om behovet av ett bilateralt avtal mellan Sverige och Danmark tillsattes för att komma vidare med lösningsarbetet.

\section{Vem påverkas}

Detta hinder berör främst de personer som har politiska förtroendeuppdrag inom den grupp som dagligeller veckopendlar över en nationsgräns. Totalt pend- lar cirka 70000 personer över en nordisk nationsgräns. Andelen med förtroendeuppdrag är förhållandevis liten, men den kan komma att öka framöver.

\section{Förslag till lösning}

En gränsarbetare som är förtroendevald i bosättningslandet skulle kunna ges rätt till tjänstledighet för att fullgöra sitt uppdrag genom ändringar i nationell lagstiftning som innebär att även förtroendevalda som arbetar i grannlandet berättigas ledighet. En alternativ eller kompletterande lösning är bilaterala avtal. Rätten till ledighet skulle med en sådan lösning utgå från arbetslandets tjänstledighetsregler. Danmark har etablerat det underlag som förutsätts för att man ska kunna ingå dylika avtal.

\section{Gränshinderrådets arbete med frågan/ kommentarer från berörda regeringar}

Økonomi- og Indenrigsministeriet, Danmark:

Danmark etablerede i vinteren 2015 det fornødne retsgrundlag for at kunne indgå aftaler om ret til fravær fra arbejdet for kommunalbestyrelses- og regionsrådsmedlemmer, der grænsependler. Danmark fremsendte herefter sommeren 2016 en udkast til aftale til Sverige. Sverige har i 2017 oplyst, at man har konstateret, at Sverige også har behov for at etablere det fornødne retsgrundlag for at kunne indgå aftaler om grænsependleres ret til fravær fra arbejdet. Dette arbejde er efter det oplyste igangsat. 


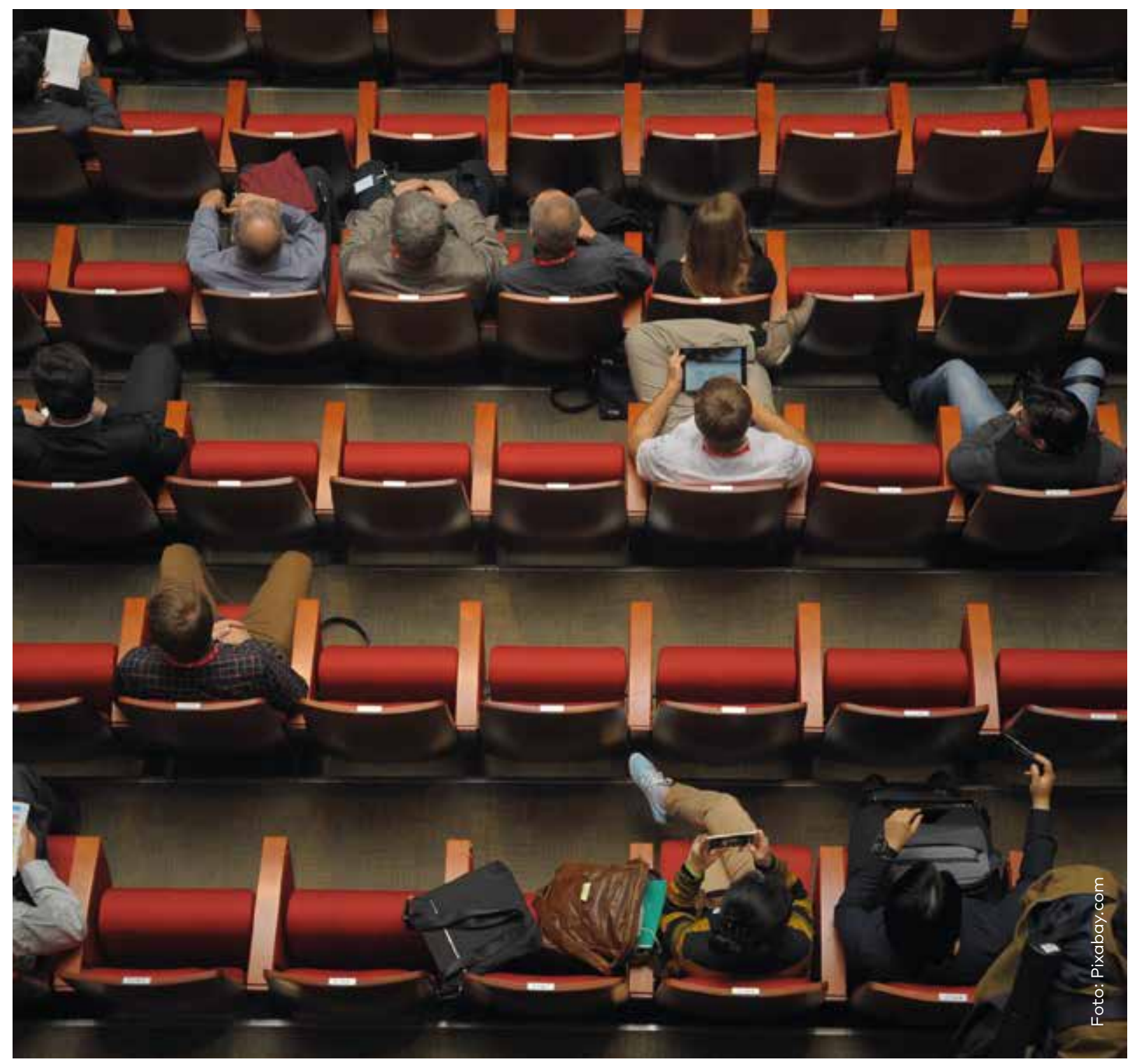

Finansdepartementet, Sverige:

Arbete pågår med frågan. Avtalsutkastet och lagtekniska frågor ses för närvarande över inom departementet.

Läs mer i Gränshinderdatabasen,

granshinder.norden.org, gränshinder nr: 14-132. 


\title{
Krav på att omfattas av olika länders arbetslöshetsförsäkring utan avbrott för att inte riskera lägre arbetslöshetsersåttning
}

\author{
Arbetstagare som får glapp i medlemsperioden i svensk arbetslöshetskassa \\ riskerar att inte få rätt till den inkomstrelaterade ersättningen utan enbart \\ den lägre grundersättningen. Glapp kan bland annat uppstå när man börjar \\ arbeta i ett annat land än Sverige eller när en gränsarbetare återvänder till \\ Sverige och söker ersättning. Detta kan även uppstå för personer som \\ enbart bor och arbetar i Sverige.
}

\author{
Ett prioriterat gränshinder av Eva Tarselius Hallgren, Sverige. Även prioriterat av MR-A. \\ Hindret kan lösas av Arbetsmarknadsdepartementet i Sverige. \\ Prioriterat av Gränshinderrådet sedan 2015.
}

\section{Bakgrund}

Sverige har en arbetslöshetsförsäkring som består av två delar. Den allmänna delen, grundförsäkringen, omfattar alla arbetstagare och egenföretagare. Den frivilliga delen, inkomstbortfallsförsäkringen, omfattar den som har varit medlem i en arbetslöshetskassa under minst tolv månader. För att få rätt till den inkomstrelaterade arbetslöshetsersättningen krävs enligt svensk praxis bland annat tolv månaders sammanhängande medlemskap i en svensk arbetslöshetskassa eller motsvarande försäkrad tid från arbete i ett annat nordiskt land. Den som får ett glapp i medlemsperioden riskerar att inte få rätt till den inkomstrelaterade ersättningen utan enbart den lägre grundersättningen.

För Sveriges del rör gränshindret personer som omfattas av inkomstbortfallsförsäkringen och som påbörjar arbete i ett annat land utan att i samband med detta bli arbetslöshetsförsäkrade där. Det kan t.ex. ske vid arbete i Danmark där arbetslöshetsförsäkringen är frivillig. Om arbetstagaren inte ansluter sig direkt när arbetet i Danmark börjar riskerar han eller hon att få en bruten försäkringsperiod. Detta kan leda till att personen i fråga vid efterföljande prövning i Sverige endast kan beviljas ersättning från den svenska grundförsäkringen.

En bruten försäkringsperiod kan även uppstå om den som har arbetat i ett annat land inte direkt blir medlem i en svensk arbetslöshetskassa efter arbete i ett annat land eller ansöker om medlemskap i fel arbetslöshetskassa (se gränshindret Anmälan till fel A-kassa kan medföra förlorad rätt till ersättning, s. 22).

I de fall den så kallade femårsregeln i den nordiska konventionen om social trygghet är tillämplig kan en person beviljas återinträde i ett nordiskt lands arbetslöshetsförsäkring under förutsättning att ansökan om medlemskap görs inom åtta veckor från det att personen lämnade ett annat nordiskt lands arbetslöshetsförsäkring. Risken för glapp vid återinträde i den svenska arbetslöshetsförsäkringen minskar därmed i de ärenden där den nordiska konventionen är tillämplig. 
Gränshindret motsvaras av nr B12 i rapporten "Gränshinder i Norden på social- och arbetsmarknadsområdet" (Nord 2012:002).

\section{Vem påverkas}

Personer som inte upprätthåller en sammanhängande försäkringstid (medlemsperiod) när de börjar arbeta i annat land eller återvänder till Sverige.

\section{Juridisk orsak}

Svensk praxis kräver bland annat tolv månaders sammanhängande medlemskap i en svensk arbetslöshetskassa eller motsvarande försäkrad tid från arbete i ett annat nordiskt land.

\section{Förslag till lösning}

En nordisk expertgrupp har i rapport Nord 2012:002 slagit fast att det behövs ett förtydligande i lagstiftningen om att det krävs tolv månaders sammanhängande medlemskap i en arbetslöshetskassa för att få rätt till ersättning från inkomstbortfallsförsäkringen i Sverige. Ett eventuellt klargörande skulle kunna medföra att en period ska betraktas som obruten, även om en viss del av den de facto är oförsäkrad. Den danska arbetslöshetsförsäkringens så kallade åttaveckorsregel kan här vara till vägledning.

\section{Gränshinderrådets arbete med frågan/ kommentarer från berörda regeringar}

Arbetsmarknadsdepartementet, Sverige:

Det pågår en intern översyn av arbetslöshetsförsäkringen vid Arbetsmarknadsdepartementet i Sverige som bland annat omfattat frågor som rör avbrott i medlemskapet och vissa andra frågor som tidigare utretts av den parlamentariska socialförsäkringsutredningen. En departementsskrivelse remitterades i december 2016 och regeringen beslutade om en proposition till riksdagen i november 2017.

I propositionen föreslås att det ska framgå tydligt av lagen att rätten till inkomstrelaterad ersättning förutsätter medlemskap under minst tolv sammanhängande månader samt att regeringen eller den myndighet som regeringen bestämmer ska kunna meddela föreskrifter om vissa avbrott i medlemskapet som arbetslöshetskassan ska bortse från när medlemsvillkoret prövas. De nya reglerna föreslås träda i kraft under 2018.

Läs mer i Gränshinderdatabasen, granshinder.norden.org, gränshinder nr: 14-004. 


\title{
Åldersgräns för inträde i en svensk arbetslöshetskassa
}

\author{
I Sverige kan en person inte få inträde i en arbetslöshetskassa efter \\ att han eller hon har fyllt 64 år. Detta kan skapa problem för den \\ som har arbetat i ett annat land och blir arbetslös. Den som inte \\ är medlem i en arbetslöshetskassa kan inte få inkomstrelaterad \\ arbetslöshetsersättning i Sverige.
}

Ett prioriterat gränshinder av Eva Tarselius-Hallgren, Sverige.

Prioriterat av Gränshinderrådet sedan 2017.

\begin{abstract}
Bakgrund
Inkomstrelaterad arbetslöshetsersättning lämnas till den som har varit medlem i en arbetslöshetskassa under minst tolv månader, under förutsättning att medlemmen efter det senaste inträdet i kassan har uppfyllt arbetsvillkoret, se 7 § och 12 § lagen (1997:238) om arbetslöshetsförsäkring (ALF). Av artiklarna 61 och 65 i förordning $\mathrm{nr}$ 883/2004 följer att den som har arbetat i en annan medlemsstat inom EU/EES eller i Schweiz under vissa förutsättningar kan tillgodoräkna sig eller sammanlägga de anställnings-, egenföretagar- eller försäkringsperioder som han eller hon fullgjort där när rätten till arbetslöshetsersättning prövas i Sverige. Därigenom kan en arbetslös person beviljas inkomstrelaterad ersättning från Sverige eftersom en tillgodoräkningsbar försäkringsperiod från EU/EES eller Schweiz kan likställas med medlemskap i en svensk arbetslöshetskassa. Detta förutsätter dock att inträde beviljas i en svensk arbetslöshetskassa. Eftersom den som har fyllt 64 år inte har rätt att bli medlem i en arbetslöshetskassa riskerar vissa personer att gå miste om inkomstrelaterad ersättning.
\end{abstract}

Åldersbegränsningen för rätt till medlemskap har identifierats som ett gränshinder för gränsarbetare i Parlamentariska socialförsäkringsutredningens delbetänkande (SOU 2011:74). Den har vidare varit föremål för prövning av Kammarrätten i Stockholm (mål $\mathrm{nr}$ 4799-14) som ansåg att bestämmelsen inte kunde tillämpas i förhållande till en migrerande arbetsta- gare som senast hade arbetat i ett annat land inom EU/EES. Domstolen ansåg att bestämmelsen kan hindra eller avskräcka en arbetstagare från att lämna landet för att arbeta i en annan medlemsstat. Enligt domstolen utgjorde bestämmelsen ett hinder för den fria rörligheten och den ansågs därigenom stå i strid med gemenskapsrätten.

Gränshindret motsvaras av nr B16 i rapporten "Gränshinder i Norden på social- och arbetsmarknadsområdet" (Nord 2012:002).

En nordisk expertgrupp framhåller i rapporten att de nordiska länderna har olika åldersgränser för när en person kan börja ta ut sin ålderspension. Länderna har även olika övre åldersgränser för utbetalning av arbetslöshetsersättning. Expertgruppen anser inte att detta i sig utgör ett gränshinder.

\section{Förslag till lösning}

Expertgruppen anser i rapporten Nord 2012:002 att det krävs en lagändring i svensk nationell rätt för att lösa gränshindret.

Detta har även den svenska parlamentariska socialförsäkringsutredningen föreslagit i sitt delbetänkande I gränslandet - Social trygghet vid gränsarbete (SOU 2011:74). Danmark har i kungörelsen om arbetslöshetsförsäkringen om att arbeta bland annat inom EES och i utlandet i övrigt med tillhörande vägledning preciserat, att om man går med i en arbetslöshets- 


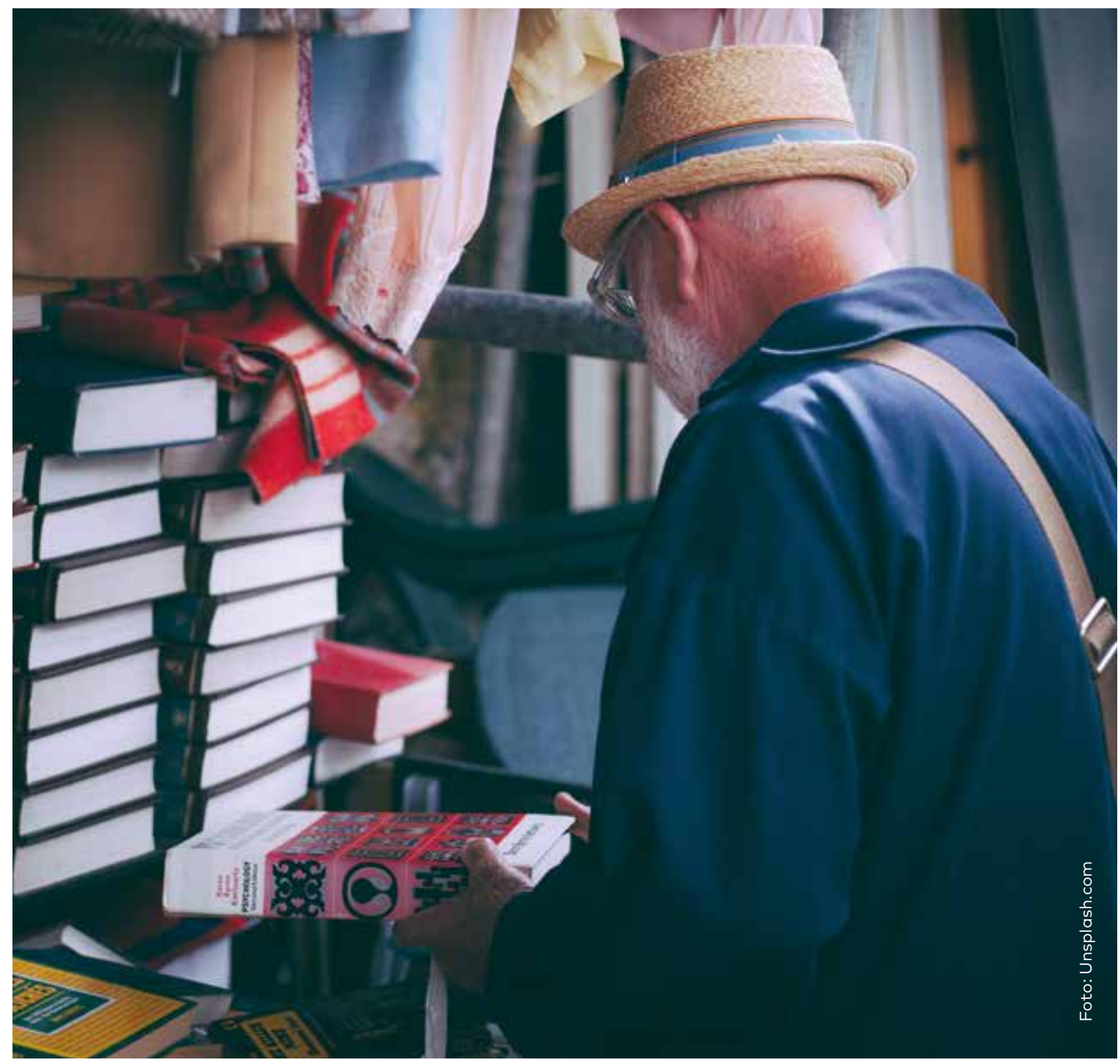

kassa som helt arbetslös gränsarbetare betraktas detta som en överflyttning.

\section{Gränshinderrådets arbete med frågan/ kommentarer från berörda regeringar}

Arbetsmarknadsdepartementet, Sverige:

Det pågår en intern översyn av arbetslöshetsförsäkringen vid Arbetsmarknadsdepartementet i Sverige som omfattar vissa frågor som tidigare utretts av den parlamentariska socialförsäkringsutredningen. En departementsskrivelse remitterades i december 2016 och regeringen beslutade om en proposition till riksdagen i november 2017.
I propositionen föreslås att rätten till medlemskap i en arbetslöshetskassa ska gälla till månadsskiftet före den månad den sökande fyller 65 år. De nya reglerna föreslås träda i kraft under 2018.

Läs mer i Gränshinderdatabasen,

granshinder.norden.org, gränshinder nr: 14-092. 


\title{
Rått till inkomstrelaterad arbets- löshetsersättning i Sverige efter "arbeidsavklaringspenger" från Norge
}

\author{
Den som ansöker om arbetslöshetsersättning i Sverige efter att ha uppburit \\ arbeidsavklaringspenger (AAP) i Norge kan gå miste om inkomstrelaterad \\ arbetslöshetsersättning. Eftersom perioder med AAP inte betraktas som \\ försäkringsperioder som ger rätt till arbetslöshetsersättning i Norge, kan de \\ inte läggas till grund för inkomstrelaterad arbetslöshetsersättning i Sverige.
}

Ett prioriterat gränshinder av Svein Ludvigsen, Norge.

Prioriterat av Gränshinderrådet sedan 2017.

\section{Bakgrund}

Den som har arbetat i ett annat EU- eller EES-land och blir arbetslös kan under vissa förutsättningar få arbetslöshetsersättning i bosättningslandet på grund av försäkrings- och anställningsperioder som har fullgjorts i det andra landet. Uppgifter om sådana perioder ska lämnas i intyg PD U1 som utfärdas av myndigheterna i arbetslandet.

Arbeidsavklaringspenger (AAP) är en förmån som lämnas till den som har nedsatt arbetsförmåga på grund av sjukdom och som söker arbete. Den som uppbär AAP omfattas av den norska socialförsäkringen (Trygden) men förmånen ger inte rätt till arbetslöshetsersättning i Norge. Perioder med AAP kan därför inte intygas som försäkringsperioder som ger rätt till arbetslöshetsersättning av de norska myndigheterna. Enligt uppgift från Grensetjänsten Norge-Sverige är det i nuläget ca 300 personer som är skrivna i Sverige och uppbär AAP i Norge.

Till följd av en överenskommelse mellan svenska och norska myndigheter om att information om perioder med AAP kan lämnas i ett följebrev till intyg PD U1 kan dessa perioder styrkas och därmed ligga till grund för beräkning av ramtid i den svenska arbetslöshetsförsäkringen. Med denna överenskommelse löstes ett gränshinder som i vissa fall hindrade den som uppburit AAP i Norge från att få arbetslöshets- ersättning i Sverige. Den som har uppburit AAP i Norge riskerar fortfarande att gå miste om inkomstrelaterad arbetslöshetsersättning i Sverige.

För att få inkomstrelaterad arbetslöshetsersättning i Sverige krävs enligt praxis medlemskap i svensk arbetslöshetskassa under tolv sammanhängande månader. Försäkringsperioder från Norge kan tillgodoräknas i den svenska arbetslöshetsförsäkringen och likställs då med medlemskap i svensk a-kassa. Eftersom perioder med AAP i Norge inte betraktas som försäkringsperioder som ger rätt till arbetslöshetsersättning i Norge kan de inte läggas till grund för inkomstrelaterad arbetslöshetsersättning i Sverige.

Under 2017 uppgår grundbeloppet i den svenska arbetslöshetsförsäkringen till högst 365 SEK per dag och inkomstrelaterad arbetslöshetsersättning kan uppgå till högst 910 SEK per dag. Båda dessa belopp beskattas.

\section{Vem påverkas}

Den som ansöker om arbetslöshetsersättning i Sverige efter att ha uppburit arbeidsavklaringspenger $\mathrm{i}$ Norge.

\section{Förslag till lösning}

För att lösa hindret krävs troligen en ändring i norsk eller svensk lagstiftning. 


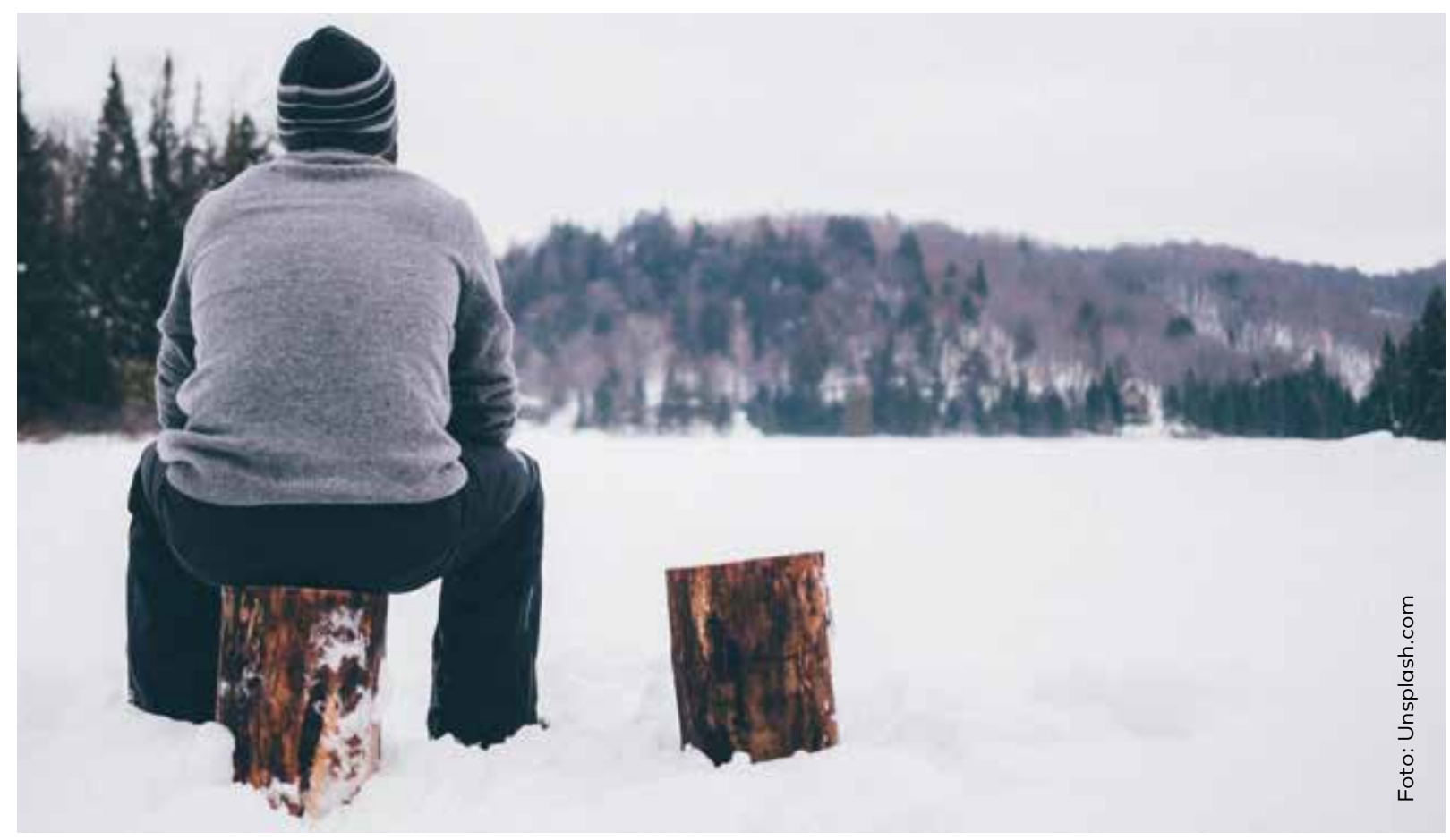

\section{Gränshinderrådets arbete med frågan/ kommentarer från berörda regeringar}

Arbeids-og sosialdepartementet, Norge:

För att få inkomstrelaterad arbetslöshetsersättning i Sverige krävs enligt praxis medlemskap i svensk arbetslöshetskassa under tolv sammanhängande månader.

Försäkringsperioder från Norge katillgodoräknas i den svenska arbetslöshetsförsäkringen och likställs då med medlemskap i svensk a-kassa. Eftersom perioder med AAP i Norge inte betraktas som försäkringsperioder som ger rätt till arbetslöshetsersättning i Norge kan de inte läggas till grund för inkomstrelaterad arbetslöshetsersättning i Sverige.

Slik grensehinderet er beskrevet, gjelder det praktiseringen av vilkårene for rett til svensk inntektsbasert arbeidsløshetsforsikring. Dette innebærer at grensehinderet ikke vil kunne løses ved endringer eller tilpasninger i norske regler eller praksis. Arbeids- og sosialdepartementet kan derfor ikke bidra til å løse grensehinderet, verken ensidig eller i samarbeid med svenske myndigheter og institusjoner.

Eventuelle endringer $\mathrm{i}$ det svenske regelverket og $\mathrm{i}$ praktiseringen av dette, vil måtte gjøres av svenske myndigheter. Den videre kontakt vedrørende oppfølgingen av dette grensehinderet bør derfor rettes til det svenske Arbetsmarknadsdepartementet som rette mottaker.

Arbetsmarknadsdepartementet, Sverige: Problemet bottnar i att tiden med AAP inte kan anses vara försäkrad tid, då tiden inte heller ger rätt till arbetslöshetsersättning i Norge. Arbetsmarknadsdepartementet i Sverige bedömer att detta skulle vara mycket svårt att lösa genom en ändring i svensk lagstiftning.

Läs mer i Gränshinderdatabasen, granshinder.norden.org, gränshinder nr: 17-012. 


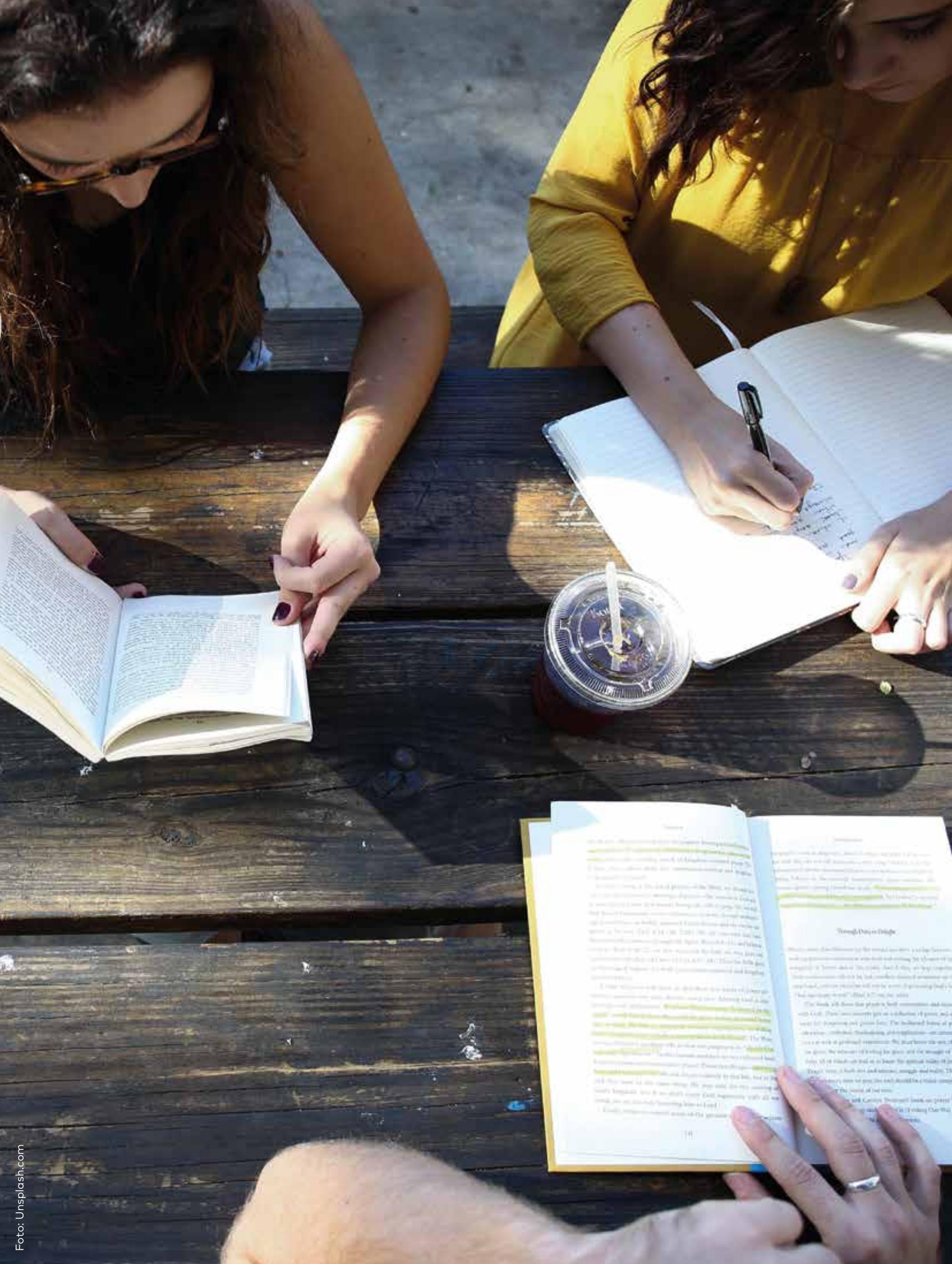




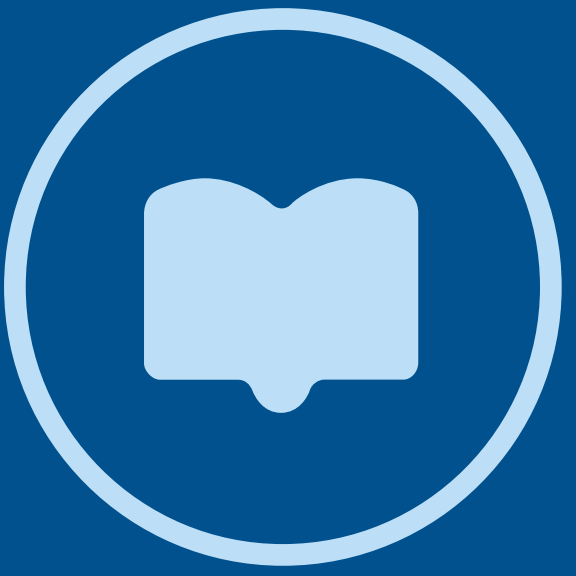

Hinder po̊ utbildningsområdet 


\section{EU:s mobilitetsprogram}

\section{Nationella regler försvårar för ungdomar som står långt från arbetsmark- naden att göra praktik och delta i utbildning i andra EU- och EES-länder.}

Ett prioriterat gränshinder av Eva Tarselius Hallgren, Sverige.

Hindret hanteras av arbetsmarknadsdepartementen i de nordiska länderna. Kontakter har tagits med Arbetsförmedlingen och Myndigheten för ungdoms- och civilsamhällesfrågor i Sverige.

Prioriterat av Gränshinderrådet sedan 2015.

\section{Bakgrund}

Några länder i Norden har svårt att använda EU:s mobilitetsprogram för icke-formellt och informellt lärande. EU-programmet Erasmus+ Ung och Aktiv, som erbjuder unga möjligheter till praktik (inklusive volontärarbete) och utbildning är ett sådant exempel.

I Sverige har Arbetsförmedlingen, Europeiska socialfondens råd (ESF-rådet) och Myndigheten för ungdoms- och civilsamhällesfrågor lyft fram att det finns behov av en förändring av rådande regelverk.

Det är främst unga som står långt från arbetsmarknaden som påverkas negativt av de nationella reglerna och hur de tillämpas. Ungdomars återinträde i utbildning eller arbete riskerar därmed att försvåras. Både Island och Sverige har identifierat problemet (i Sverige redovisas det i regeringens proposition 2013/14:191 Med fokus på unga - en politik för goda levnadsvillkor, makt och inflytande).

\section{Vem påverkas}

De unga människor i de nordiska länderna som står längst från arbetsmarknaden.

\section{Gränshinderrådets arbete med frågan/ kommentarer från berörda regeringar}

Arbetsmarknadsdepartementet, Sverige:

Det svenska arbetsmarknadsdepartementet bedömer att den förordning som brukar omnämnas som huvudorsaken till att svenska ungdomar som är inskrivna på Arbetsförmedlingen undviker att använda sig av mobilitetsprogrammet inte i sig utgör ett hinder. Unga har möjlighet att lämna det arbetsmark- nadspolitiska programmet Jobb- och utvecklingsgarantin och sedan återinträda i garantin om det finns intresse att t.ex. prova på volontärarbete utomlands.

En stor del av den problematik som framförts handlar om svårigheterna att återinträda i jobbgarantin för unga (JOG). Arbetsmarknadsdepartementet erfar dock, efter dialog med berörda myndigheter att inga aktivitetsperioder inom EU:s mobilitetsprogram varar längre än tolv månader. Då det under vissa omständigheter finns möjlighet att återinträda i JOG om avbrottet har varat högst ett år, borde återinträde vara möjligt. Bedömningen är därför att det arbetsmarknadspolitiska regelverket inte utgör ett hinder för deltagande i EU:s mobilitetsprogram. Stöd för att återgå i arbete kan även lämnas genom andra arbetsmarknadspolitiska insatser och åtgärder.

Läs mer i Gränshinderdatabasen, granshinder.norden.org, gränshinder nr: 15-006. 


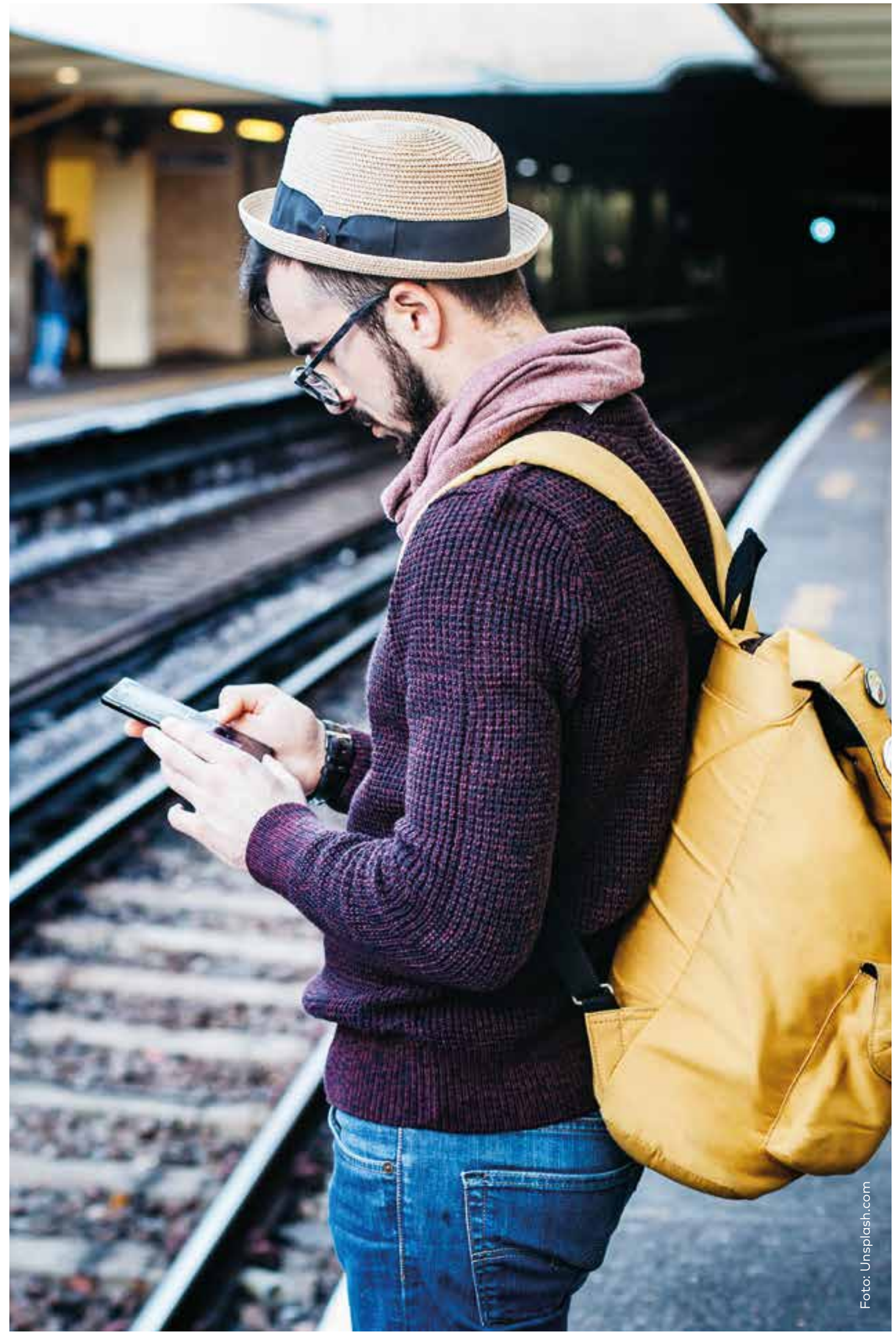




\title{
Erkännande av yrkeskvalifikationer
}

\author{
Många yrken i Norden är reglerade antingen från statligt håll, exempelvis i lag \\ eller genom branschspecifika föreskrifter. Eftersom kraven skiljer sig mellan \\ de nordiska länderna uppstår det hinder för arbetstagarnas fria rörlighet.
}

Ett prioriterat gränshinder av Dagfinn Høybråten, Nordiska ministerrådet, Svein Ludvigsen, Norge, Kim Andersen, Danmark, Risto E.J. Penttilä, Finland och John Johannessen, Färöarna. Även prioriterat av MR-U.

Detta är ett av de 15 gränshinder som prioriterades av arbetsmarknadens parter i Norden vid näringslivskonferensen på Børsen i Köpenhamn den 30 april 2015.

Arbetet med hindret kräver koordinering mellan de nordiska arbetsmarknads- och utbildningsministerierna.

Nationella dialogmöten gällande branschrelaterade yrkeskvalifikationer med arbetsmarknadens parter har avhållits under 2017.

Prioriterat av Gränshinderrådet sedan 2014.

\section{Bakgrund}

Nordiska ministerrådet har som en del av programmet Hållbar nordisk välfärd låtit konsultföretaget DAMVAD göra analysen "Lovregulerede erhverv og velfærdsprofessioner". Det är en rapport som bland annat kartlägger alla statligt reglerade yrken i Norden. Resultaten visar att antalet reglerade yrken varierar stort mellan de nordiska länderna; Island med 171 statligt lagreglerade yrken har flest, Norge har 165 och Danmark 162. Sverige har 91 och Finland 74. Analysen visar också att de yrken som är statligt reglerade ger färre gränshinder än de som är branschspecifikt reglerade.

Arbetet med gränshindret är nära kopplat till implementeringen av EU:s nya yrkeskvalifikationsdirektiv. Det är dock svårt att hitta en slutlig lösning på gränshindret eftersom problematiken rör flertalet branscher och många länder.

Gränshinderrådet har därför valt en mer långsiktig strategi och fokuserar sitt arbete på att underlätta en samnordisk implementering av direktivet. På sikt kommer en ökad koordinering av implementeringen av direktivet förhoppningsvis att bidra till ett minskat antal problem på grund av skillnader i kvalifikationsoch utbildningskrav.
De tjänstemän som arbetar med implementeringen träffades i februari 2015, där de nationella koordinatorerna för direktivet deltog. Nätverket samlades på nytt i juni och oktober 2015.

\section{Förslag till lösning}

Underlätta erfarenhetsutbyte under genomförandefasen av EU:s yrkeskvalifikationsdirektiv.

\section{Gränshinderrådets arbete med frågan/ kommentarer från berörda regeringar}

Uddannelses- og Forskningsministeriet, Danmark:

Det er konstateret, at der er flere branchereguleringer for erhverv, der ikke er lovregulerede i enkelte nordiske lande. Branchereguleringer kan i praksis begrænse adgang til udøvelse af de erhverv. Hvis det afklares indenfor hvilke konkrete erhverv i nordiske lande der findes branchereguleringen og disse optages i EU anerkendelsesdirektivets bilag 1 vil det bidrage til, at nordiske statsborgere udnytter de rettigheder og garantier, som anerkendelsesdirektivet giver.

\section{Svein Ludvigsen, Norge:}

Det synes som det er både myndighets- og bransjebestemte bestemmelser som er til hinder for godkjenning av yrkeskvalifikasjoner. Grensehinderrådet 


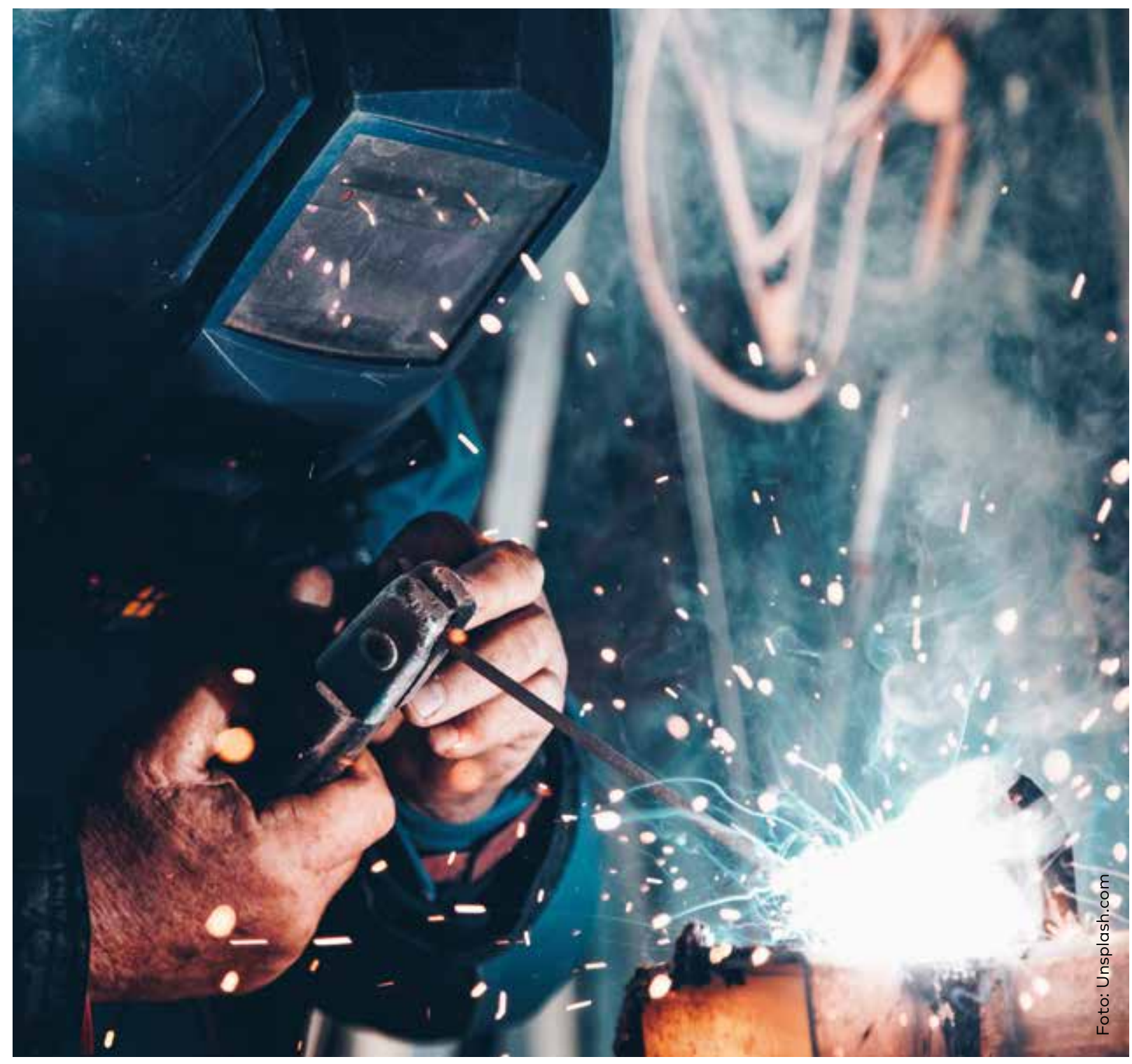

avventer en rapport fra A-sektoren som et prosjekt på gang for å kartlegge problemene.

Risto E.J. Penttilä, Finland:

I väntan på A-sektorns rapport kan konstateras att inga problemfall under året noterats i Finland.

Läs mer i gränshinderdatabasen,

granshinder.norden.org, gränshinder nr: 14-122. 


\section{Begränsade möjligheter för svenska läkare att genomföra sin allmäntjänst- göring på Ảland}

\section{Sedan nittiotalet har det varit möjligt för läkare att göra sin allmäntjänst- göring på Åland för att få svensk läkarlegitimation.}

Ett prioriterat gränshinder av Eva Tarselius-Hallgren, Sverige och Gunnar Westerholm, Åland.

Prioriterat av Gränshinderrådet sedan 2017.

\section{Bakgrund}

För att få svensk läkarlegitimation krävs att den som har en läkarexamen gör minst 18 månaders allmäntjänstgöring. Möjligheten att genomföra sådan allmäntjänstgöring i annat land har hittills inte varit reglerad. Sedan nittiotalet har allmäntjänstgöring för svensk läkarlegitimation kunnat fullgöras på Åland. I det reviderade yrkeskvalifikationsdirektivet (EU-direktiv 2005/36, ändringsakt 2013/55) har införts möjligheter för yrkesutövare i reglerade yrken att tillgodoräkna sig praktisk tjänstgöring i ett annat EU eller EES-land. Enligt direktivet kan medlemsländerna dock fastställa en rimlig begränsning av den del av yrkespraktiken som kan genomföras utomlands.

I Sverige har Socialstyrelsen beslutat att högst nio månader av den minst 18 månader långa allmäntjänstgöring som krävs för att få svensk läkarlegitimation kan genomföras i ett annat EU- eller EES-land. Socialstyrelsen har även beslutat att placeringar inom allmänmedicin och psykiatri, som är obligatoriska moment i allmäntjänstgöringen, ska genomföras i Sverige för att allmäntjänstgörande läkare ska kunna förvärva nödvändiga kunskaper och kompetens om svenska lagar och förhållanden genom klinisk erfarenhet.

\section{Vem påverkas}

Detta gränshinder påverkade den som har en läkarexamen och vill göra den allmäntjänstgöring som krävs för att få en svensk läkarlegitimation. Hindret påverkade även sjukvården i Åland som miste allmäntjänstgörande läkare från Sverige. Utöver detta är AT-tjänstgöringen en viktig form av samarbete mellan hälsovården i Sverige och Åland då Åland fungerar som en utbildningsplats.

\section{Gränshinderrådets arbete med frågan/ kommentarer från berörda regeringar} Gunnar Westerholm, Åland:

Ålands landskapsregering anser att frågan för Ålands del är löst. Förhandlingar har förts med svenska socialstyrelsen och med finska myndigheter för att trygga ömsesidig nytta av att svenska AT-läkare kan tjänstgöra på Åland.

Socialdepartementet, Sverige:

Akademiska sjukhuset i Uppsala har sedan 2009 ett avtal med Ålands hälso- och sjukvård vilket gör det möjligt för studenter med svensk läkarexamen att genomföra sin allmäntjänstgöring på Åland utifrån Socialstyrelsens föreskrift om allmäntjänstgöring. AT-läkaren har sedan haft möjlighet att ansöka om svensk läkarlegitimation efter genomförd allmäntjänstgöring på Åland. Akademiska sjukhuset i Uppsala intygar med början under 2017 i varje enskilt fall att tjänstgöringen motsvarar kraven i AT-föreskriften och kommer erbjuda en särskild utbildning i svensk lagstiftning. Detta har skapat förutsättningar för att Socialstyrelsen efter en bedömning i varje enskilt fall kan besluta om legitimation för den som har svensk läkarexamen och har fullgjort AT på Åland. Socialstyrelsen har anpassade sina föreskrifter under 2017 för att skapa förutsättningar att fortsätta AT-tjänstgöring på Åland. Akademiska sjukhuset i Uppsala är ansvarig för att tjänstgöringen motsvarar kraven och kommer erbjuda en särskild utbildning i svensk lagstiftning. Socialstyrelsen gör en bedömning i varje enskilt fall före beslut om svensk legitimation. 


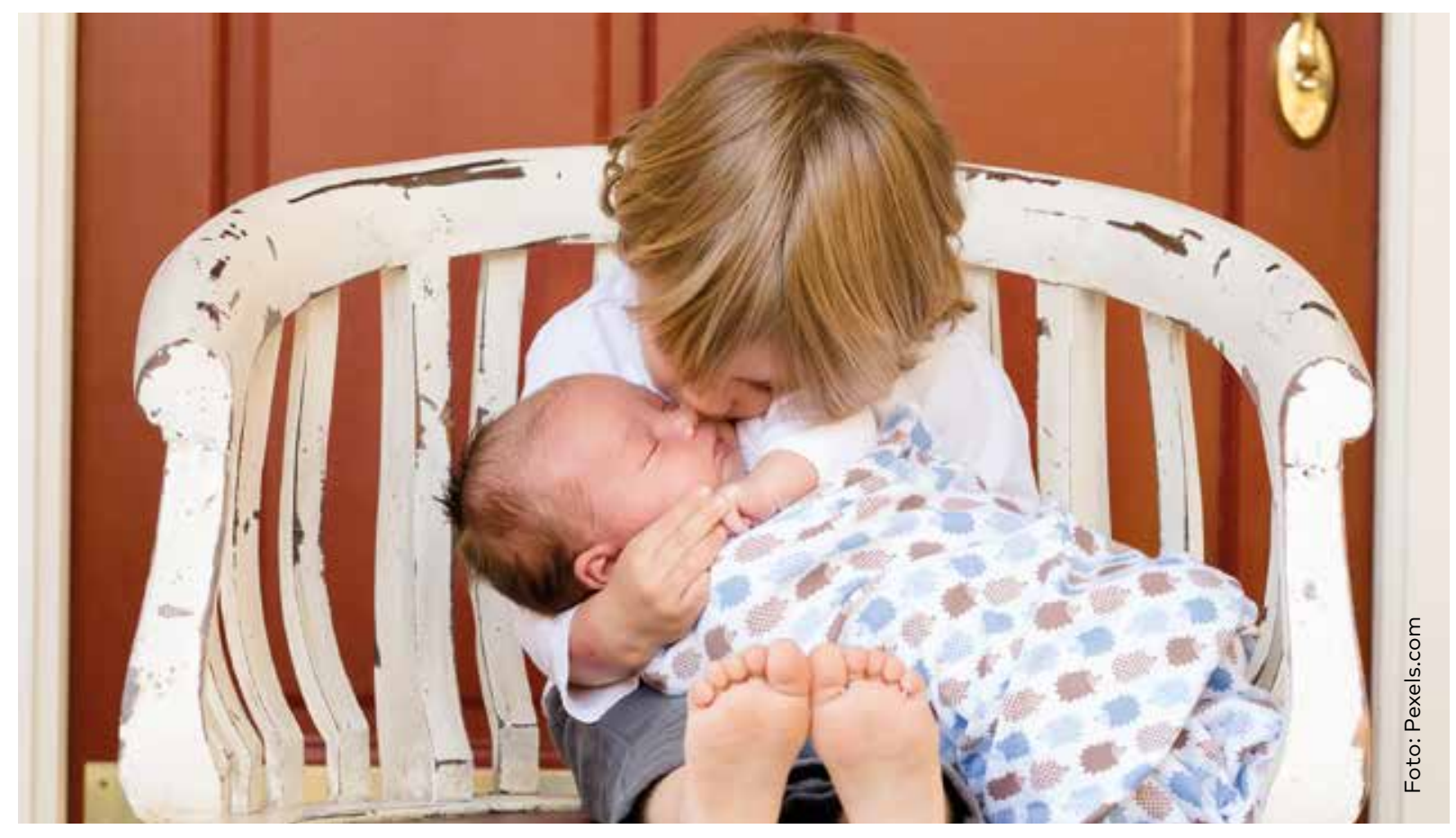

Läs mer i gränshinderdatabasen,

granshinder.norden.org, gränshinder nr: 17-014. 


\section{Ansökning till norsk gymnasieutbildning}

Ett prioriterat gränshinder av Svein Ludvigsen, Norge.

Prioriterat av Gränshinderrådet sedan 2017.

\section{Bakgrund}

Danmark, Finland, Island, Norge og Sverige har inngått en avtale om et nordisk utdanningsfellesskap på videregående nivå (gymnasium). Det følger av avtalens artikkel 1 at partene forplikter seg gjensidig til å gi utdanningssøkende fra andre nordiske land tilgang til sine lovregulerte teoretiske og yrkesrettede utdanninger på samme vilkår som egne innbyggere.

I Norge er dette imidlertid vanskelig fordi man i noen fylker, ut ifra andre lover (opplæringsloven kap.6), tolker det dit hen at søkeren må være folkeregistrert i Norge og i skolens fylkeskommune ved skolestart, og helst allerede på tidspunktet for søknad om skoleplass (1. mars), for at søknaden skal kunne godkjennes. Kravet om at søkeren skal være folkeregistrert i fylket ved tidspunktet for søknad, medfører at søkeren ikke behandles på samme vilkår som Norges egne innbyggere. Den nordiske avtalen om et utdanningsfellesskap på videregående nivå er med dette ikke gjeldende i praksis.

Det at man i Norge har krav om at man som nordisk statsborger skal fremvise dokumentasjon på leiekontrakt, arbeidskontrakt eller studieplass i Norge for å folkeregistrere seg, kompliserer forholdet ytterligere. Man får ikke studieplass før man er folkeregistrert, og man får ikke folkeregistrert seg før man har studieplass. For at man som elev i et annet nordisk land skal ha mulighet til å ta videregående skole i Norge, må man først kunne fullføre skolegangen i hjemlandet. Og det er også forståelig at man ønsker å avvente flytting til etter at man har fått svar om skoleplass (i juli).

Hallo Norden var, etter en rekke henvendelser fra frustrert nordisk ungdom som ønsket å gå videregående skole i Norge, i 2014 i kontakt med Utdanningsdirektoratet (UDIR) i Norge, som konkluderte med at:
"For at nordiske borgere skal få sine rettigheter etter avtalen om nordisk utdannings- fellesskap på videregående nivå oppfylt, skal de behandles på samme vilkår som landets egne innbyggere. I denne sammenheng må det bety at de kan sende søknad om videregående opplæring til den fylkeskommunen der vedkommende kommer til å bo. Søknaden må sendes innen søknadsfristen. Det vil være denne fylkeskommunen som har ansvaret for å oppfylle retten til videregående opplæring og som må vurdere om søkeren fyller vilkårene i forskriften kapittel 6. Kravet om at vedkommende er folkeregistrert i fylket på tidspunkt for søknaden vil medføre at søkeren ikke behandles på samme vilkår som egne innbyggere og gjelder derfor ikke her. Vi viser i denne sammenheng også til formålet med avtalen som bl.a. er å utvide mulighetene for studenter og andre som horer hjemme i et nordisk land til å få utdanning og avlegge eksamen ved de øvrige landenes utdanningsinstitusjoner."

Kunnskapsdepartementet støttet i 2014 UDIRs tolkning om at det ikke kan stilles krav til at søkeren må være folkeregistrert i Norge ved tidspunktet for søknad. Hallo Norden har i mai 2017 vært i kontakt med SIU, Senter for internasjonalisering av utdanning, som forvalter avtalen i Norge på vegne av Kunnskapsdepartementet. De stiller seg også bak en slik forståelse. Det hører til saken at fylkenes inntakskontorer opererer med ulike tolkninger av regelverket. Uansett vil Hallo Norden hevde at motstridende bestemmelser i den nordiske avtalen om utdanningsfellesskap og opplæringsloven i Norge, samt kravene for folkeregistrering i Norge, gjør at den nordiske utdanningsfellesskapsavtalen i dag ikke gjelder i Norge. 


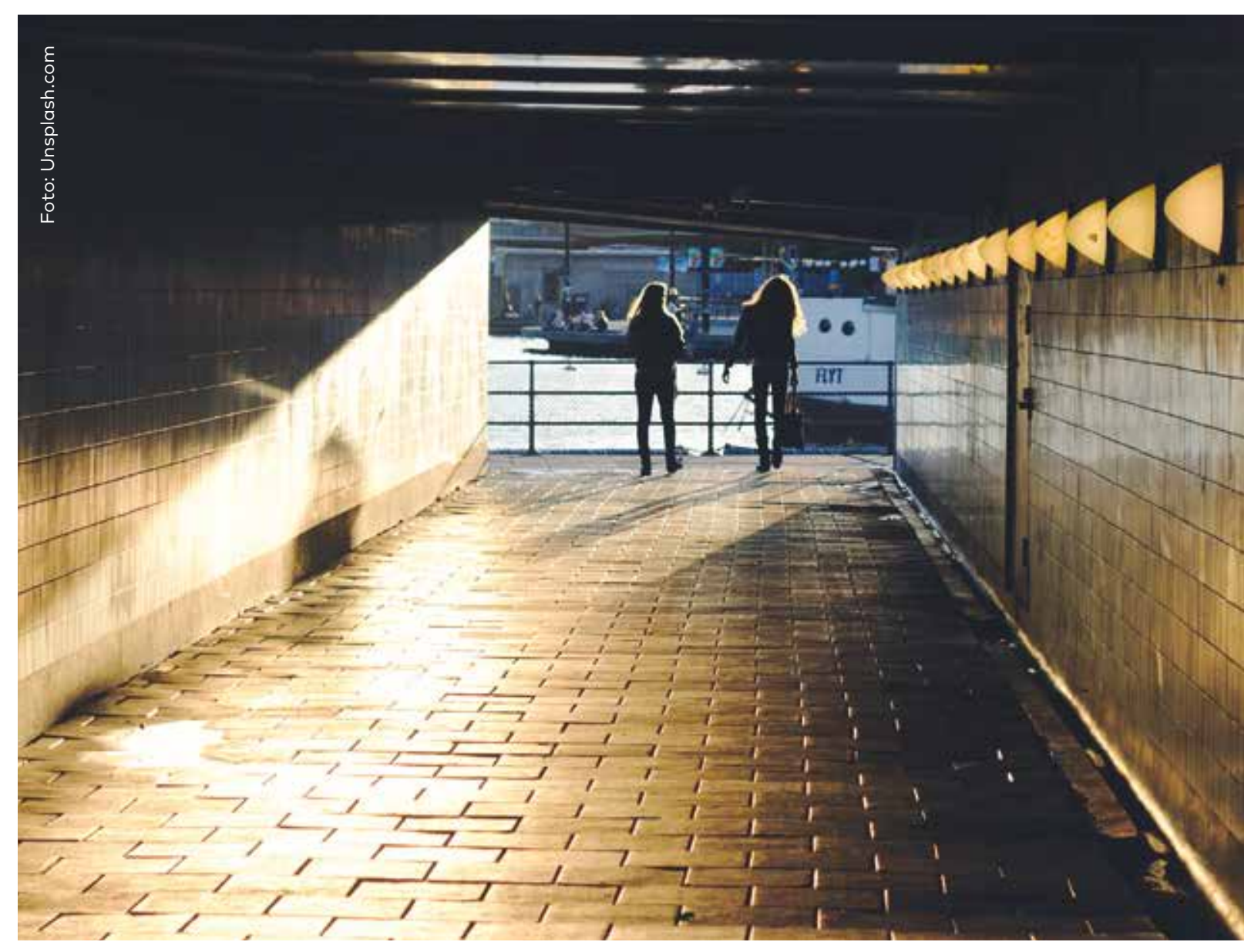

\section{Gränshinderrådets arbete med frågan/ kommentarer från berörda regeringar}

Svein Ludvigsen, Norge:

Kunnskapsdepartementet opplyser at de ikke er kjent med at avtalen om utdanningsfelleskap på videregående nivå ikke etterleves av fylkeskommunene.
Saken er reist av Hallo Norden. Grensehinderrådet har oversendt dokumentasjon fra Hallo Norden til Kunnskapsdepartementet for kommentar.

Saken er i prosess. 



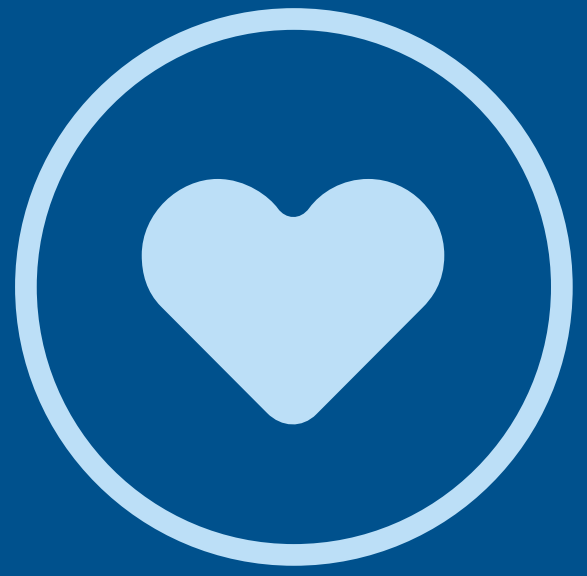

Hinder po̊ social- och hälsoområdet 


\title{
Ersättning för patientresa mellan Norge och Finland/Sverige
}

\author{
En gränspendlare med bosättning i Finland eller Sverige med arbete i Norge \\ är socialförsäkrad och skattepliktig i Norge. Han eller hon får inte ersättning \\ för sina patientresor/behandlingsresor från hemmet i Finland/Sverige till \\ sjukhuset Norge till skillnad från sina arbetskollegor med bosättning och \\ arbete Norge.
}

Ett prioriterat gränshinder av Svein Ludvigsen, Norge, Risto E.J Penttilä, Finland och

Eva Tarselius Hallgren, Sverige.

Prioriterat av Gränshinderrådet sedan 2014.

\begin{abstract}
Bakgrund
Huvudregeln är att gränsgångare ska täckas av sjukförsäkringen i sitt arbetsland. Om en finsk medborgare som är bosatt i Finland arbetar i Norge, omfattas hon eller han av det norska sjukförsäkringssystemet och ska därmed vända sig till norska hälsovårdscentraler eller sjukhus. Problemen uppstår då sådana gränsgångare hänvisas vidare till vidare utredning/ behandling vid en annan hälsovårdscentral eller sjukhus i Norge. Då betalar inte norska Pasientreiser (en myndighet under Helseøkonomiforvaltningen) ut ersättning för de resekostnader som gränsgångaren ådragit sig i samband med behandlingen.

Orsaken är att Pasientreiser kräver att alla behandlingsresor ska påbörjas och avslutas vid arbetsplatsen. För en person som är $100 \%$ sjukskriven kan det dock vara mycket svårt eller omöjligt att ta sig till arbetsplatsen från sitt hem på den finska sidan. Det innebär att personen själv måste betala kostnaderna för bil- och flygresor till behandlingsorten. För gränsgångare som bor och arbetar i norra Finland/Norge kan det då bli fråga om stora summor. Personen kan också ha svårt att ta sig till behandling/rehabilitering i sitt bosättningsland (Finland) eftersom Pasientreiser/Helseøkonomiforvaltningen inte betalar resor inom Finland.
\end{abstract}

Motsvarande gäller för en gränspendlare som är bosatt i Sverige och arbetar i Norge.

\begin{abstract}
Vem påverkas
Detta hinder påverkar samtliga medborgare som arbetar i Norge och bor i Finland eller Sverige, cirka 32300 pendlare.
\end{abstract}

\section{Ekonomiska konsekvenser}

Den totala resekostnaden är beräknad till 462 EUR för en finsk pendlare som är bosatt i Utsjoki, arbetar i Kirkenes och har behov av specialistvård i Oslo. Den motsvarande siffran för en person som pendlar från Stockholm till Oslo är 153 EUR. Uppskattningsvis berörs cirka 210 gränspendlare från Finland och Sverige av hindret. Norska staten sparar i sin tur cirka 77000 EUR på att inte lösa hindret. Närmare beräkningar finns nedan.

\section{Förslag till lösning}

Gränsgångare/nordiska arbetstagare får ersättning för reseutgifter i sitt hemland i förbindelse med läkarbesök och behandling enligt samma regler som norska och utländska arbetstagare bosatta i Norge.

\section{Gränshinderrådets arbete med frågan/ kommentarer från berörda regeringar}

Risto E.J. Penttilä, Finland:

Finland har meddelat att man är beredd att tillämpa EU-förordning 883/2004 artikel 11, 17 och 18 om rätt till vårdnad i hemlandet. Detta har meddelats $i$ brev till Norges Helse- och omsorgsdepartement den 30.6.2017. 


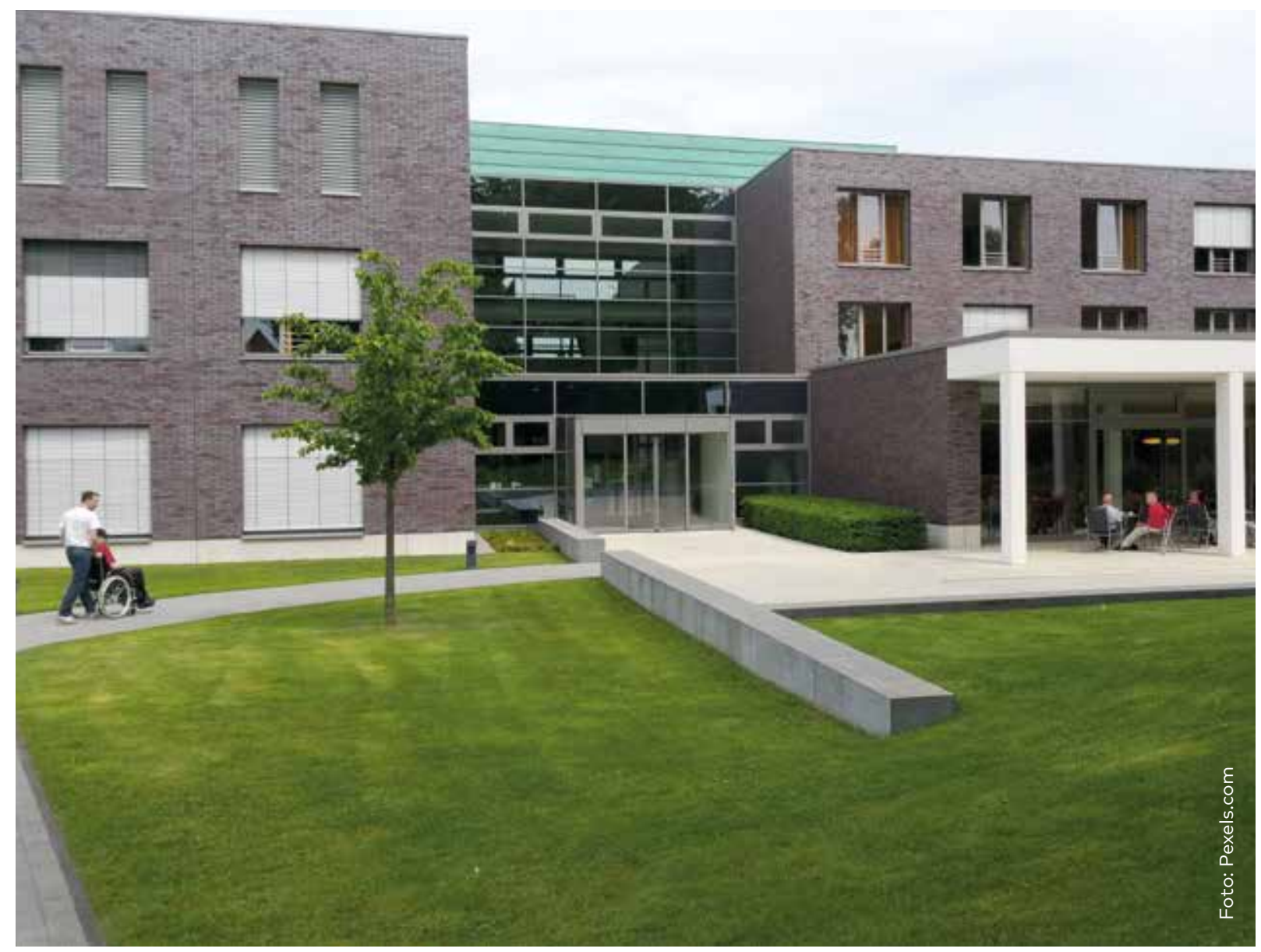

Svein Ludvigsen, Norge:

Dette grensehinderet har vært på sakslisten siden 2014. Det har ikke latt seg løse pga av manglende resiprositet landene imellom. Jeg mener saken burde vært løst fordi det berører et begrenset antall nordiske arbeidstakere. I tillegg er dette et eksempel på begrensede forutsetninger for individer og foretak å virke over grensene i Norden og på den måten styrke regionenes globale konkurransekraft. Det er nå tatt fornyet kontakt med fagministrene i et siste forsøk på å løse saken før vi eventuelt i 2018 må innse at den må avskrives som ikke løsbar.
Socialdepartementet, Sverige:

Sverige vill titta vidare på frågan i konstruktiv anda.

Läs mer i gränshinderdatabasen,

granshinder.norden.org, gränshinder nr: 14-164. 


\title{
Finska fyramånadersregeln
}

\author{
Finland införde inför utvidgningen av EU år 2004 regler om bosättningsbaserade \\ förmåner som innebär att personer som inte är bosatta i Finland och vars \\ arbetsförhållande inte är minst fyra månader långt, inte heller är försäkrade \\ för vissa socialförsäkringsförmåner som de annars hade varit försäkrade för \\ genom sin bosättning Finland.
}

Ett prioriterat gränshinder av Risto E.J. Penttilä, Finland.

Hindret kan lösas av finska Social- och hälsovårdsministeriet.

Prioriterat av Gränshinderrådet sedan 2014.

\section{Bakgrund}

När en person flyttar till Finland avgör Folkpensionsanstalten (FPA) om han eller hon ska omfattas av den finska bosättningsbaserade sociala tryggheten som FPA har hand om. Tryggheten omfattar följande förmåner: folkpension, barnbidrag, moderskapsunderstöd, bostadsbidrag, bostadsbidrag för pensionstagare, handikappförmåner, frontmannapension, garantipension och underhållsstöd. Även rätt till förmåner enligt sjukförsäkringslagen och lagen om Folkpensionsanstaltens rehabiliteringsförmåner och rehabiliteringspenningförmåner grundar sig på bosättning.

Om en person som kommer till Finland inte uppfyller villkoren för stadigvarande bosättning i Finland grundar sig rätten till FPA:s förmåner istället på arbete. Personer som omfattas av förordningarna 883/2004 och 1408/71 kan bli försäkrade och få rätt till FPA:s förmåner på basis av arbete om de under fyra månader arbetar minst 18 timmar i veckan och har en lön som motsvarar minst den lön som ska betalas enligt branschens kollektivavtal. Om det inte finns något kollektivavtal inom den aktuella branschen, ska lönen för arbetet vara minst 1154 EUR i månaden (2014) vid heltidsarbete. Detta krav brukar kallas fyramånadersregeln.

Personen är visserligen försäkrad för arbetspension, arbetsskada och olycksfallsförsäkring och har rätt till offentlig hälsovård i Finland, men har inte rätt till exempelvis barnbidrag eller sjukförsäkring (sjukdagpenning, föräldrapenning).

Fyramånadersregeln drabbar i hög grad nordiska säsongsarbetare inom turistnäringen i norra Finland.

\section{Vem påverkas}

Enligt SOLMU IV-rapporten från finska social- och hälsovårdsministeriet rör gränshindret cirka 1500 personer. Säsongsarbetare är den persongrupp som är påverkas mest av gränshindret. Utbetalningarna av sociala trygghetsförmåner till en arbetstagare är beräknade till 1307 EUR per år, och 27078 EUR per år för en familj på fyra personer.

\section{Ekonomiska konsekvenser}

Istället för fyramånadersregeln görs utbetalningen av sociala trygghetsförmåner baserat på en liknande regel för arbetsvillkor som finns i lagen om utkomstskydd för arbetslösa. Rätten till socialförsäkringsförmåner skulle i så fall träda in då personen arbetat minst 18 timmar per vecka och har en lön som motsvarar minimilönen enligt gällande kollektivavtal eller 1154 EUR per månad om det inte finns något kollektivavtal. Alternativt kunde fyramånadersregeln göras om till en enmånadsregel.

\section{Gränshinderrådets arbete med frågan/} kommentarer från berörda regeringar Risto E.J. Penttilä, Finland:

Saken är under behandling som en del av ett spets- 
projekt inom regeringen. Ett avgörande är att vänta under år 2018.

Läs mer i Gränshinderdatabasen, granshinder.norden.org, gränshinder nr: 14-008.

\section{Beräkningar}

Antagandet är att de 1500 som här nämns, är personer som under ett år har arbetat i Finland under maximalt fyra månader. Beräkningarna är gjorda utifrån antagandet att den genomsnittliga anställningstiden är tre månader.

\section{Ökade utbetalningar av sociala trygghetsförmåner}

Värdering av antalet berörda personer 


\title{
Flytt för institutionaliserade personer
}

\author{
Enligt den nordiska konventionen om socialt bistånd och sociala tjänster \\ ska de ansvariga myndigheterna samarbeta för att göra det möjligt för \\ äldre eller institutionaliserade personer att flytta till det land där de har \\ starkast personlig anknytning. Detta fungerar inte i praktiken på grund \\ av oklarheter kring betalning och ansvar.
}

Ett prioriterat gränshinder av Kim Andersen, Danmark.

Hindret ingår i avtalet från 2013 mellan den danska regeringen och samtliga partier i det danska

Folketinget om att avlägsna gränshinder i Norden.

Hindret kan lösas av socialministerierna och handläggande myndigheter i de nordiska länderna.

Prioriterat av Gränshinderrådet sedan 2014.

\section{Bakgrund}

Möjligheten för personer som behöver långvarig vård och behandling att flytta från ett nordiskt land till ett annat grundar sig på artikel 9 i den nordiska konventionen om socialt bistånd och sociala tjänster från 1994.

I alla nordiska länder är det kommunerna som är ansvariga för denna vård.

Konventionen ger kommunen befogenhet och skyldighet att medverka till flyttningen till ett annat nordiskt land och eventuellt träffa överenskommelse om fördelning av kostnaderna för vård och behandling i de båda länderna. Det finns dock inga sådana direkta regler gällande fördelningen av kostnaderna. I praktiken uppstår därför problem för den enskilde eftersom de ansvariga myndigheterna i ut- och inflyttningsländerna är osäkra på vem som ska stå för flytt- och vårdkostnader.

\section{Vem påverkas}

Hindret påverkar antagligen inte så många, men det har stora konsekvenser för enskilda personer som drabbas.

\section{Förslag till lösning}

Länderna arbetar för att revisionen av den Nordiska konventionen om socialt bistånd och sociala tjänster ska innehålla tydliga regler om ansvarsfördelning och eventuell fördelning av kostnader mellan ländernas myndigheter.

Samtidigt bör man utveckla ett bättre informationssystem mellan kommunerna i de nordiska länderna som medför att kommunerna känner till artikel 9 i den nordiska konventionen.

\section{Gränshinderrådets arbete med frågan/} kommentarer från berörda regeringar Børne- og Socialministeriet, Danmark:

Spørgsmålet inddrages i forbindelse med den igangværende revision af Bistandskonventionen.

Läs mer i gränshinderdatabasen, granshinder.norden.org, gränshinder nr: 14-104. 


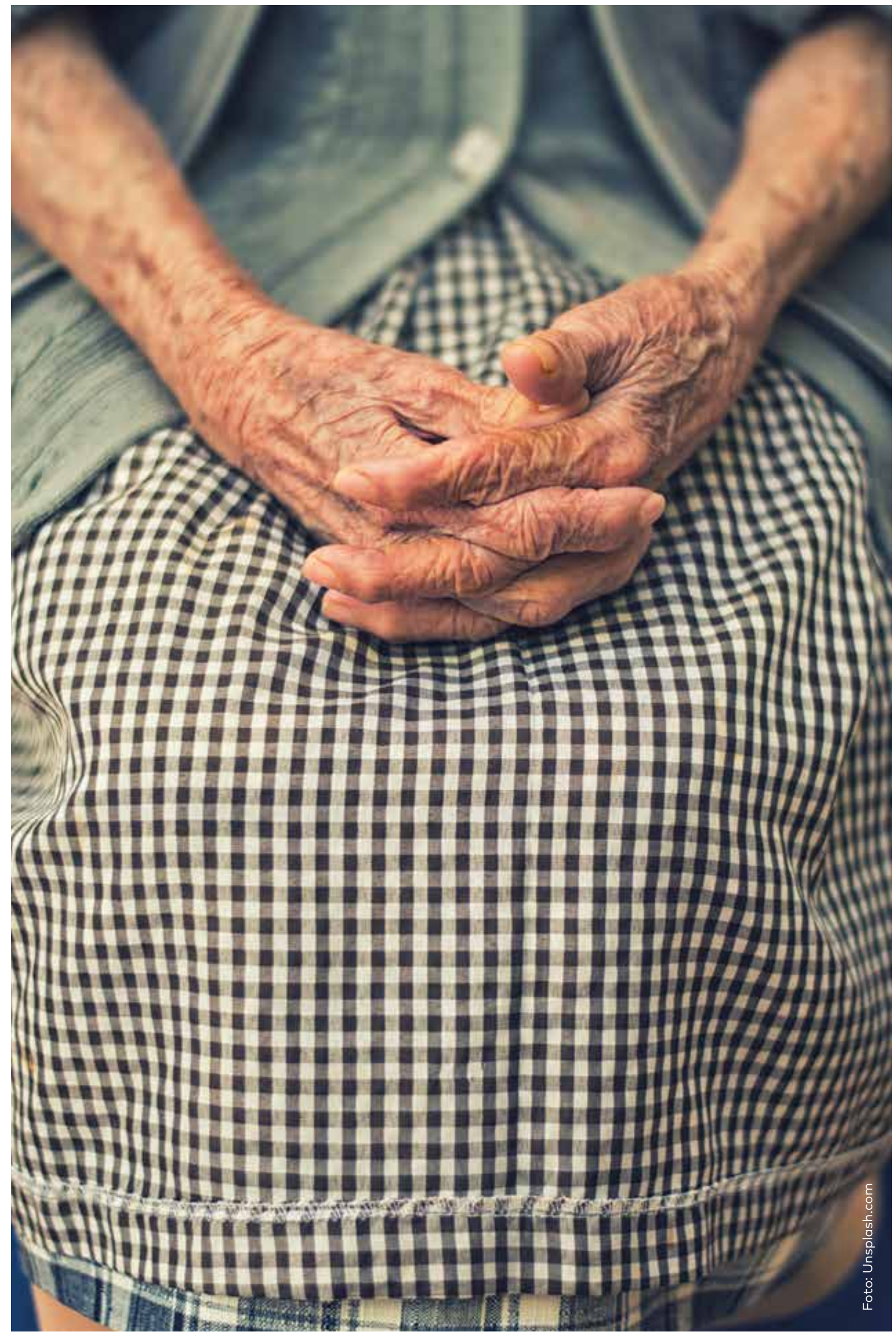




\title{
Olika krav på märkning av läkemedel och olika krav på språk för bipacksedel
}

\author{
De olika krav som ställs på märkning av läkemedel i de nordiska länderna \\ och att bipacksedeln ska vara på landets eget språk kan leda till ett mindre \\ utbud av läkemedel på den nordiska marknaden. Dessa krav utgör \\ handelshinder som särskilt drabbar små marknader som den isländska.
}

Hindret är prioriterat av Siv Fridleifsdottir, Island, Jørgen S. Søndergaard, Grönland och

John Johannessen, Färöarna.

Detta är ett av de 15 gränshinder som prioriterades av arbetsmarknadens parter i Norden vid näringslivskonferensen på Børsen i Köpenhamn den 30 april 2015.

Prioriterat av Gränshinderrådet sedan 2016.

\section{Beskrivning av hindret}

Även om de flesta krav som ställs på märkning av läkemedel inom Norden har harmoniserats återstår ändå olika nationella krav gällande t.ex. den röda triangel som vissa länder har valt att ange på förpackningen. Länderna har också olika krav på språket för den bipacksedel som ligger i förpackningen.

Därtill har de nordiska länderna olika krav gällande de frister inom vilka ändringar av förpackningspåskrift och bipacksedel ska genomföras/implementeras i produktionspartierna och lanseras på marknaden.

Dessa olikheter i förutsättningarna mellan de nordiska länderna utgör handelshinder. De drabbar särskilt små marknader som den isländska. Full harmonisering av dessa krav skulle underlätta för de nordiska länderna att göra gemensamma inköp av läkemedel.

\section{Vem påverkas}

Brukare av läkemedel i Norden och läkemedelsindustrin.

\section{Förslag till lösning}

Med gemensamma regler om märkning av läkemedel i Norden blir de krav som ställs på märkning av läkemedel helt harmoniserade och inga nationella särregler återstår.
För att reducera tiden vid godkännande av ändringar av förpackningspåskrifter och bipacksedlar kunde de nordiska länderna tillämpa samma tidsfrister. Detta kunde genomföras vid ett nära samarbete mellan de nordiska läkemedelsmyndigheterna och innehavare av godkännande för försäljning av läkemedel i de nordiska länderna.

För att underlätta de krav som ställs på att information som bipacksedeln lämnas på landets eget språk kunde de nordiska länderna gemensamt driva ett förslag om att ändra EU-reglerna så att det blir möjligt för apotek som lämnar ut medicinen att skriva ut bipacksedeln på det språk som patienten förstår. Aktuella bipacksedlar kunde finnas tillgängliga på de nationella läkemedelsmyndigheternas hemsidor på Internet. De farmaceutiska grossisterna skulle därmed inte behöva bryta upp förpackningarna och lägga i nationella bipacksedlar innan de distribueras till apoteken, vilket är praxis på en del av den isländska marknaden. En sådan ordning skulle göra det möjligt för apoteken att lämna information på det språk som konsumenten önskar och förstår. Det skulle också göra det lättare för de nordiska länderna att göra gemensamma upphandlingar av läkemedel och därmed uppnå lägre priser. 


\section{Gränshinderrådets arbete med frågan/ kommentarer från berörda regeringar}

Siv Fridleifsdottir, Island:

Hindringen og lösningen har blitt introdusert i diverse sammenheng i 2016 som fremkom i siste årsrapport. I januari 2017 skickade Gränshinderrådet ett brev till ordföranden för MR-S och Nordiska ministerrådets generalsekreterare för att påtala vikten av att ministerrådet inleder ett samarbete om frågan om märkning av läkemedel och språket på bipacksedlar för att undanröja detta gränshinder.

I 2017 var hindringen belyst av den islandske helseminister Óttarr Proppé på MR-S möte og av islandske medlemmer på EK-S möte. Videre arbeid med hindringen fikk stötte.

Dette har ledt til at EK-S besluttet 7.-8. juni i Bergen "ÄK-S beslutade att frågan om "märkning av läkemedel" och andra eventuella gränshinder på läkemedelsområdet ska behandlas på ett möte mellan de Nordiska läkemedelsmyndigheterna under 2017. ÄK-S bad Nordiska ministerrådets sekretariat, i samarbete med Norge, att organisera och inkalla till detta möte".

De som forbereder mötet har fått synspunkter om at det er viktig at sjefene for de nordiske läkemedelinstituttene og representanter fra departementene deltar i mötet. Det er også viktig at Grönland, Færöyene og
Åland deltar med sine representanter selvom de ikke alle har egene läkemedelinstitutter.

I februar 2018 skal et möte avholdes mellan läkemedelsstyrelserna i de nordiska länderna.

Den 16. august ble hindringen introdusert bl.a. av Islands medlem av Grensehinderrådet på möte med den islandske utenriksminister Guðlaugur Pór pórðarsson som ba embedsverket om å forberede å ta den opp på EFTA nivå.

Den 18. august introduserte Islands medlem av Grensehinderrådet, Siv Friðleifsdóttir, hindringen til sjefene i läkemedelsstyrelserna (deltakere i Nordic Meeting of Heads of Medicines Agencies).

Den 19. september ble Islands medlem av Grensehinderrådet, Siv Friðleifsdóttir, inbydt til möte hos mittengruppen i Nordisk Råd for å introdusere hindringen. Gruppen fremförte i oktober et medlemsförslag om digital bipacksedel till läkemedel, A 1741/ tillväxt, til Nordisk Råd.

Island, Färöarna och Grönland kommer att fortsätta att följa hur frågan utvecklas under 2018.

Läs mer i gränshinderdatabasen, granshinder.norden.org, gränshinder nr: 17-016. 


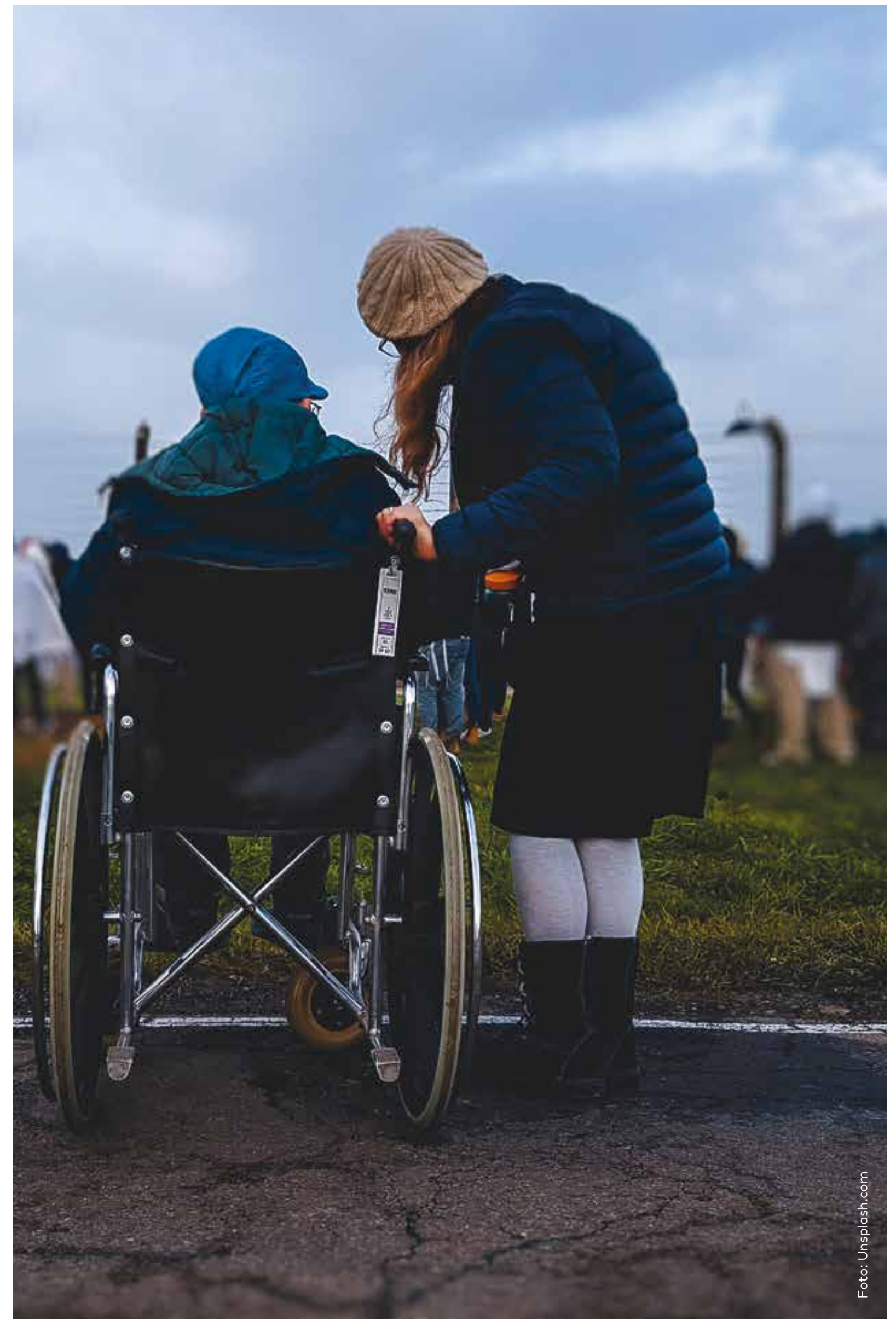




\section{Man kan inte få närståendepenning om inte både vårdare och den sjuke är försåkrade i Sverige}

\section{Den som arbetar i Sverige kan inte få svensk närståendepenning för att vårda en svårt sjuk närstående som inte bor i Sverige.}

Hindret prioriteras av Eva Tarselius Hallgren, Sverige och Gunnar Westerholm, Åland.

Prioriterat av Gränshinderrådet sedan 2016.

\section{Bakgrund}

Närståendepenning är en ersättning som lämnas till den som vårdar en närstående som har en sjukdom som är ett påtagligt hot mot dennes liv. Enligt svenska regler kan närståendepenning endast lämnas när både vårdaren och den sjuke är försäkrade i Sverige. Detta innebär att den som arbetar i Sverige inte kan erhålla närståendepenning för att vårda en sjuk anhörig som är försäkrad i ett annat land än i Sverige.

\section{Vem påverkas}

Arbetstagare i Sverige som vill vårda en svårt sjuk närstående som är försäkrad i ett annat nordiskt land.

\section{Förslag till lösning}

Att Sverige släpper på kravet att den som vårdas av en nära anhörig måste vara försäkrad i Sverige för att vårdaren ska kunna erhålla närståendepenning.

\section{Gränshinderrådets arbete med frågan/ kommentarer från berörda regeringar}

Socialdepartementet, Sverige:

Det pågår ett arbete på Socialdepartementet med att analysera och se över denna fråga. Betänkandet Svensk social trygghet i en globaliserad värld (SOU 2017:5) har varit ute på remiss och Socialdepartementet har nyligen börjat att sammanställa de inkomna remissvaren. Därefter får bedömas hur betänkandet ska beaktas jämfört med aktuellt gränshinder och hur frågan ska beredas vidare.
Gunnar Westerholm, Åland:

l ett betänkande inför en större lagstiftningsprocess i Sverige har Sveriges regering sänt ut "Betänkandet SOU 2017:05 - Svensk social trygghet i en globaliserad värld" på en remissrunda med sista svarsdag den 31 augusti 2017. Gränshinderrådet har sänt följande synpunkter som är bekräftat mottagna av socialdepartementet i Sverige.

"En grupp som drabbas hårt av hittillsvarande system är sjöanställda. I en värld där fartyg trafikerar rutter som har lite att göra med det land där fartyget är registrerat, och besättningen kan ha ytterligare ett annat boendeland, så faller många mellan stolarna $i$ och med kravet om samma försäkringsland för vårdnadstagare och givare.

Utgående från de sjöanställda som har sin anställning på svenskflaggade fartyg ber Gränshinderrådet att det tas i beaktande i slutbetänkandet att även dessa kan tillgodogöra sig socialförsäkringen till fullo även om boendelandet är ett annat, bland annat gällande ersättning $i$ det fall en anhörig kan vara vårdnadsgivare som är socialförsäkrad $i$ ett annat land än den $i$ Sverige försäkrade vårdnadstagaren."

Läs mer i gränshinderdatabasen, granshinder.norden.org, gränshinder nr: 17-004. 


\title{
Färdtjänst för funktionshindrade
}

\author{
De nationella reglerna om rätt till färdtjänst gör det dyrt och besvärligt för \\ personer med funktionshinder att resa inom Norden. Problemet beror delvis \\ på att beslut om rätt till färdtjänst görs av olika organ och på olika nivåer $i$ \\ de nordiska länderna.
}

Ett prioriterat gränshinder av Svein Ludvigsen, Norge.

Prioriterat av Gränshinderrådet sedan 2017.

\section{Bakgrund}

De nordiska länderna har olika nationella färdtjänstsystem för funktionshindrade. Gemensamt för dessa system är att de ska bidra till att funktionshindrade ska kunna delta i utbildning, arbete och fritidsaktiviteter. I Danmark finns det en rad olika färdtjänstsystem, beroende på målet med transporten. Det mest använda är i kommunal regi och det finns begränsningar angående kostnaderna för varje resa. Finlands, Islands och Sveriges system är kommunala. I Norge är färdtjänst inte lagstadgad, men administreras och finansieras av fylkeskommunerna. Flera länder har regler som begränsar det geografiska området inom vilket ordningen kan utnyttjas. Ett projekt genomfördes av Nordiska handikappförbundet 2008-2010 mellan Köpenhamn, Oslo, Reykjavik och Stockholm angående funktionshindrades transport. Projektet visade att en rörelsehindrad person kunde använda transportutbudet i de fyra kommunerna vid besök där. Projektet har fått positiv respons från användarna, men det fanns även svårigheter med de administrativa rutinerna och beställningarna mellan kommunerna.

Gränshindret motsvaras av nr A5 i rapporten "Gränshinder i Norden på social- och arbetsmarknadsområdet" (Nord 2012:002).

\section{Vem påverkas}

Nordiska medborgare med funktionshinder som vistas tillfälligt i ett annat nordiskt land.

\section{Förslag till lösning}

En nordisk expertgrupp har i rapporten Nord

2012:002 ansett att generell handikappvänlig utform- ning av kollektiva transportmedel kan minska behovet av färdtjänst. Då specialtransport är nödvändig ser gruppen flera möjliga lösningar. Det kan göras ändringar i nationella regelverk, som gör det möjligt att utnyttja lokal färdtjänst vid kortvariga resor i andra länder. Nationella regelverk kan öppnas upp för avtal i enskilda fall om användning av besökskommunens eller besökslandets färdtjänst, med eventuell reglering av återbetalning. Projektet som testades 2008-2010 bör analyseras närmare. Expertgruppen föreslår att denna fråga tas upp i samband med den eventuella revideringen av den nuvarande nordiska konventionen om socialt bistånd och sociala tjänster.

\section{Gränshinderrådets arbete med frågan/ kommentarer från berörda regeringar \\ Svein Ludvigsen, Norge: \\ Saken er tatt opp i forbindelse med revisjonen av den nordiske Bistandskonventionen, og Grensehinderrå- det avventer resultatet fra denne. \\ Läs mer i Gränshinderdatabasen, granshinder.norden.org, gränshinder nr: 14-136.}




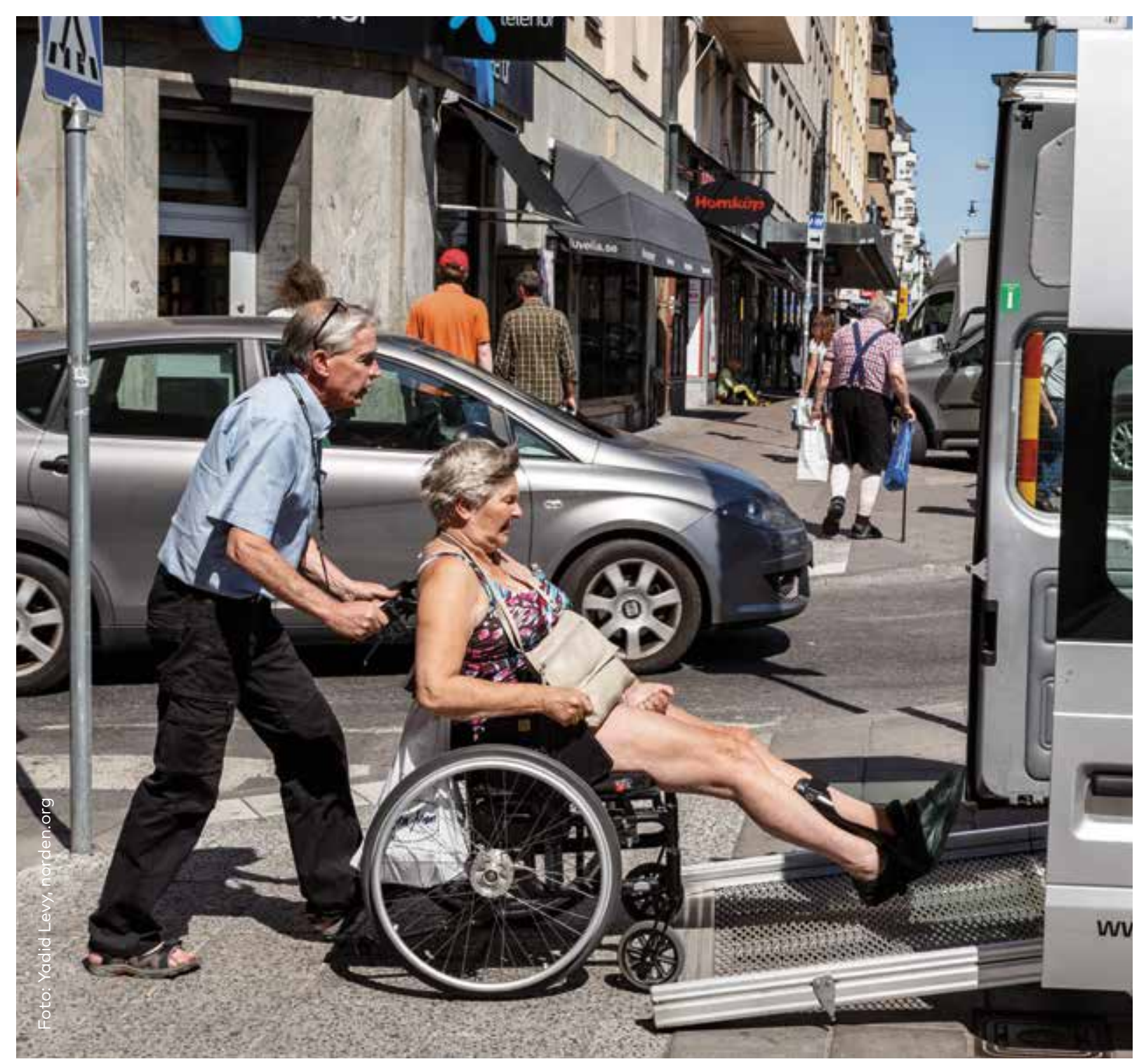




\section{Ledarhund vid resa}

\section{Idag behandlas personer som reser med ledarhund inom EU på samma sätt som turister som reser med sällskapsdjur. Detta innebär höga kostnader och långa behandlingstider för vaccinationer och intyg för hunden.}

Ett prioriterat gränshinder av Svein Ludvigsen, Norge och Siv Fridleifsdottir, Island.

Prioriterat av Gränshinderrådet sedan 2017.

\section{Bakgrund}

Alla de nordiska länderna har samma krav för införsel av tjänstehundar (t.ex. bärgnings-, bomb- och narkotikahund samt ledarhundar för synskadade, hörselskadade och rörelsehindrade) som för sällskapshundar. I Finland, Danmark och Sverige gäller EU-förordning 576/2013. För Norge gäller EU förordning 998/2003 fram tills genomförandet av förordning 576/2013 är slutfört. De grundläggande EU kraven är ID-märkning, rabiesvaccination och EU-pass. Förordningen ger ingen möjlighet till undantag från dessa regler och medger inte heller att medlemsstaterna ställer ytterligare krav. I Norge och Finland är kompletterande krav behandling för rävars dvärgbandmask 1-5 dagar före införsel.

Reglerna för hur vaccinationerna ska genomföras, till exempel vad gäller tidsfrister och kontroller, är harmoniserade inom EU. Island har undantag från EES-avtalets bilaga (kapitel I del 1.1. nr. 10, EU-förordning 998/2003). Grönland och Färöarna omfattas inte av förordningen. För Grönlands del är området reglerat av Fødevarestyrelsen i Danmark. Varken Grönland eller Färöarna har särskilda regler för ledarhundar. Vid införsel måste hundarna vara ID-märkta och vaccinerade mot rabies. Det går att ansöka om dispens när hundar tas ut från Island.

Ovanstående regler innebär kostnader som varierar mellan länderna. Kostnaderna utgör en mindre del av de totala kostnaderna vid hundhållning och kräver att resan planeras långt i förväg. De flesta nordiska kollektivtransportbolag (flyg, tåg, båt och buss) godkänner att ledarhundar tas med gratis. Gränshindret motsvaras av nr A2 i rapporten "Gränshinder i Norden på social- och arbetsmarknadsområdet" (Nord 2012:002).

\section{Vem påverkas}

Nordiska medborgare med synskador.

\section{Förslag till lösning}

En nordisk expertgrupp framhåller i rapporten Nord 2012:002 att det är veterinära hänsyn som är orsak till kraven. Det är därför knappast möjligt eller önskvärt att ge ledarhundar dispens från EU-reglernas veterinära krav vid in- och utförsel av hundar. God och lättillgänglig information om vaccinations- och karantänkraven i de nordiska länderna är viktig. Expertgruppen påpekar att hundens status som hjälpmedel kan understrykas. Det kan också övervägas om personer som reser med ledarhund inom EU skulle kunna få hjälp med kostnader för vaccinationer och intyg för ledarhundar.

\section{Gränshinderrådets arbete med frågan/ kommentarer från berörda regeringar}

Svein Ludvigsen, Norge:

Hverken Landbruks- og matdepartementet eller Arbeids- og sosialdepartementet kan se at dette lenger er et grensehinder. Førerhunder er spesielt verdifulle hunder og det vil være risikabelt og ikke vaksinere dem. Det er heller ikke høye kostnader eller lange behandlingstider forbundet med vaksinering. Krav om sjekk av titernivå er opphevet. Dermed er grensehinderet løst i Norge.

Siv Friðleifsdóttir, Island:

Ett brev har sänts till den isländske fiskeri- och lantbruksministern, Dorgerður Katrín Gunnarsdóttir. Siv 


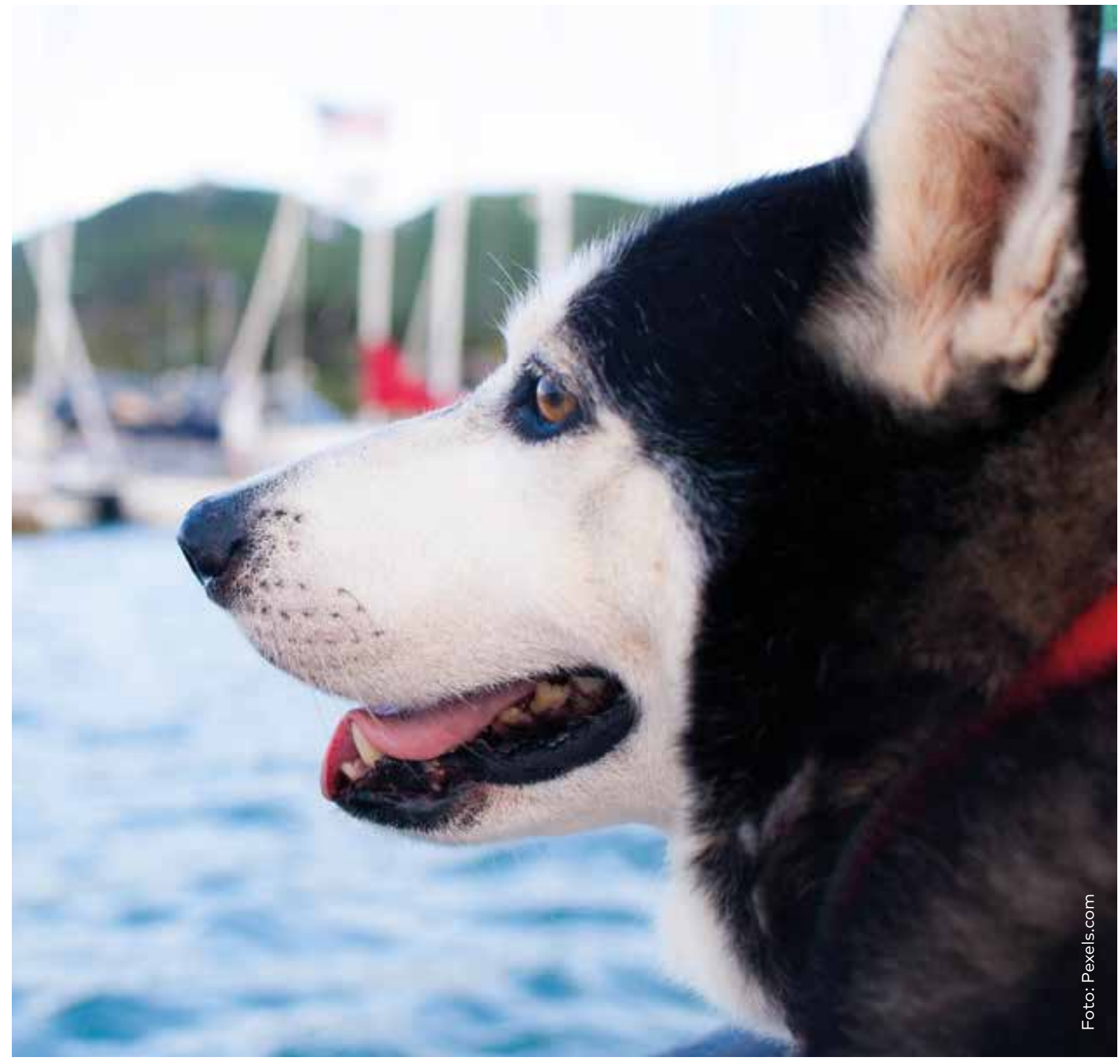

Friðleifsdóttir har varit i kontakt med ministern som uttryckte att en process ska sättas igång på Island. I fölge svar fra Kristján Skarphéðinsson, departementsjef, er processen slik at ministeren har utnevnt en dansk ekspert som skal forberede ny rikiskovurdering vedrörende import av kjældyr (i hovedsak hunder og katter). I den risikovurderingen blir ledarhund vid resa inkludert.

Läs mer i Gränshinderdatabasen,

granshinder.norden.org, gränshinder nr: 14-130. 


\section{Personlig assistent vid flytt}

\section{Allvarligt funktionshindrade personer med personlig assistent har svårigheter att få med sin assistent vid flytt. Olika länder vill bedöma rätten till assistent nationellt och anställningsförhållandena för personliga assistenter skiljer sig mellan länderna.}

Ett prioriterat gränshinder av Svein Ludvigsen, Norge.

Prioriterat av Gränshinderrådet sedan 2017.

\begin{abstract}
Bakgrund
Rätten till personlig assistent är knuten till det land där den enskilde personen bor. Länderna har olika villkor för att få en personlig assistent, omfattningen av assistans och hur sådan assistans organiseras. Nivån på och formerna för assistans beror i alla länder på hur personens behov bedöms. Det tas ställning till hur mycket stöd personen behöver med utgångspunkt i graden av funktionshinder och om personen bor på institution eller i eget hem.
\end{abstract}

Inget land har bestämmelser som anger att assistenter måste flytta eller ta arbete långt från sin egen hemort i fall den som behöver assistans flyttar. Detta leder till att assistenten vanligtvis slutar när den som använder assistansen flyttar långt bort. Konsekvensen blir att den som behöver personlig assistent kan få problem på grund av avbrott i assistansen under tiden efter flytten. Reglerna för personlig assistans vid kortvariga resor är reglerade på olika sätt, och den möjligheten är även beroende av om assistenten är villig att följa med på resan. Frågan diskuterades på en konferens som ordnades av Nordens Välfärdscenter i Stockholm i april 2013. Gränshindret motsvaras av nr A3 i rapporten "Gränshinder i Norden på social- och arbetsmarknadsområdet" (Nord 2012:002)

\section{Förslag till lösning}

Det kunde, i de nationella lagstiftningarna, införas en möjlighet att ansöka om tidsbegränsad assistans inför flytt, eller en möjlighet till förhandsgodkännande före flytt. Detta gäller under förutsättning att det visar sig lämpligt vid en närmare analys av ekono- miska och administrativa konsekvenser. En nordisk expertgrupp föreslår i rapporten Nord 2012:002 att denna fråga tas upp i samband med den eventuella revideringen av den nuvarande nordiska konventionen om socialt bistånd och sociala tjänster. Införandet av ett nordiskt samarbetsorgan för socialt bistånd och sociala tjänster har också diskuterats som ett möjligt lösningsförslag.

\section{Gränshinderrådets arbete med frågan/ kommentarer från berörda regeringar}

Svein Ludvigsen, Norge:

Helse- og omsorgsdepartementet opplyser at rettighetsfestet brukerstyrt personlig assistanse (BPA) er et kommunalt ansvar, og dimensjonert ut fra et konkret timebehov. Tilbudet er knyttet til opphold i kommunen, men kan i utgangspunktet for kortere perioder fritt disponeres innenfor den tidsrammen som er innvilget og gjeldende arbeidsrettslige bestemmelser. For permanent flytting vil konsekvensen av oppholdsprinsippet medføre at rettighetshaveren må søke sin nye bostedkommune om brukerstyrt personlig assistanse.

Saken er tatt opp i forbindelse med revisjonen av den nordiske Bistandskonventionen, og Grensehinderrådet avventer resultatet fra denne.

Läs mer i Gränshinderdatabasen, granshinder.norden.org, gränshinder nr: 14-124. 


\title{
Flytt med handikappfordon
}

\author{
Personer med handikappfordon (t.ex. bil) kan inte ta med sig sitt handikapp- \\ fordon över gränsen vid flytt, utan måste ansöka om ett nytt fordon i det \\ nya bosättningslandet. På grund av lång handläggningstid kan detta \\ innebära att flytt blir omöjligt för personer som har ett starkt och dagligt \\ behov av ett transportmedel av detta slag.
}

Ett prioriterat gränshinder av Svein Ludvigsen, Norge.

Prioriterat av Gränshinderrådet sedan 2017.

\section{Bakgrund}

De nordiska ländernas nationella regler om handikappfordon är mycket olika. Vem som ger stöd för anskaffning, villkoren för rätt till stöd, vilket stöd som ges och hur stor del av kostnaderna som täcks varierar mellan länderna. Detta innebär att en person som har rätt till stöd för anskaffning, uppgradering och underhåll av handikappfordon i ett land, inte nödvändigtvis har sådan rätt i ett annat land. Finland, Island och Sverige har i huvudsak samma regler för flytt med handikappfordon som för flytt med andra fordon. En person kan ta med sitt handikappfordon vid flytt till annat land på samma sätt som andra fordon man äger. Efter flytten måste man, på samma sätt som för andra fordon få fordonet besiktigat och registrerat enligt reglerna i inflyttningslandet. Efter flytten har man inte rätt till stöd för nya anpassningar och liknande från utflyttningslandet, utan måste följa regelverk och ordningar i det nya bosättningslandet. Villkor som är knutna till egenbetalning för fordonet, eller till avbetalning av lån beviljat för anskaffning av det kan göra det svårt att exportera fordonet, speciellt i Danmark, Island och Norge. Nivån på avgifter vid import, besiktning och registrering av fordon varierar mellan länderna. Detta kan ha betydelse för om det är ekonomiskt fördelaktigt att ta med fordon från ett annat land, eller om det är förmånligare att ansöka om stöd till ett nytt efter flyttningen.

Gränshindret motsvaras av nr A6 i rapporten "Gränshinder i Norden på social- och arbetsmarknadsområdet" (Nord 2012:002).

\section{Förslag till lösning}

En nordisk expertgrupp anser i rapporten Nord 2012:002 att det är viktigt med god information om regelverket till enskilda, så att de ska kunna planera inför en flytt. Expertgruppen anser att en ändring av nationella regler som hindrar eller försvårar export av handikappfordon skulle kunna övervägas. En möjlighet till tidsbegränsad användning i ett annat land än utflyttningslandet, i kombination med kortare handläggningstid för ansökan om stöd till inköp av nytt fordon i inflyttningslandet, skulle kunna förenkla processen när det inte är möjligt eller önskvärt att ta med sig handikappfordonet i samband med flytten.

\section{Gränshinderrådets arbete med frågan/ kommentarer från berörda regeringar}

Svein Ludvigsen, Norge:

Regelverket er ikke til hinder for at en bruker etter økonomisk oppgjør med NAV kan ta kjøretøyet med seg utenlands på samme vilkår som andre bileiere. Ved flytting til Norge kan bruker søke om ny trygdebil, men slike søknader vil ikke bli prioritert foran andre søknader. Arbeids- og sosialdepartementet opplyser at de ikke mottar henvendelser om dette fra brukere. Saken må avskrives som ikke løsbar.

Läs mer i Gränshinderdatabasen, granshinder.norden.org, gränshinder nr: 14-102. 


\section{Rätt till arbetslöshetsersättning efter permittering och uppsägning efter arbete i Norge}

\section{Personer som bor i Sverige och har varit permitterade från sitt jobb i Norge eller Finland har problem att få arbetslöshetsersättning.}

Ett prioriterat hinder av Risto E.J. Penttilä, Finland.

Prioriterat av Gränshinderrådet sedan 2017.

\section{Bakgrund}

Gränshindret uppstod på nytt när Norge fr.o.m. 1.6.2012 började tillämpa EU-förordning 883/04. NAV slutade då att använda E-blanketter och började utfärda PDU1-intyg för personer vars norska anställning hade upphört. På U1-intyget finns ingen plats att redovisa permitteringsperioder som likställda anställningsperioder. NAV redovisar därför permitteringsperioden under punkten "Utbetald arbetslöshetsersättning" vilket får till följd att tid med permitteringsersättning inte kan räknas in i ett svenskt arbetsvillkor. Detta har inneburit att många sökande som har varit permitterade i Norge mer än 6 månader under det senaste året inte uppfyller något arbetsvillkor vid återkomst till Sverige. Två personer har överklagat sina avslagsbeslut till förvaltningsrätten men har inte fått rätt i domstolsprövningen.

\section{Gränshinderrådets arbete med frågan/ kommentarer från berörda regeringar} Risto E.J. Penttilä, Finland:

Kontakt tagen till Finlands Social och hälsovårdsministerium för kontakt med motsvarande svenska myndighet.

Läs mer i Gränshinderdatabasen, granshinder.norden.org, gränshinder nr: 14-022. 


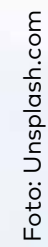

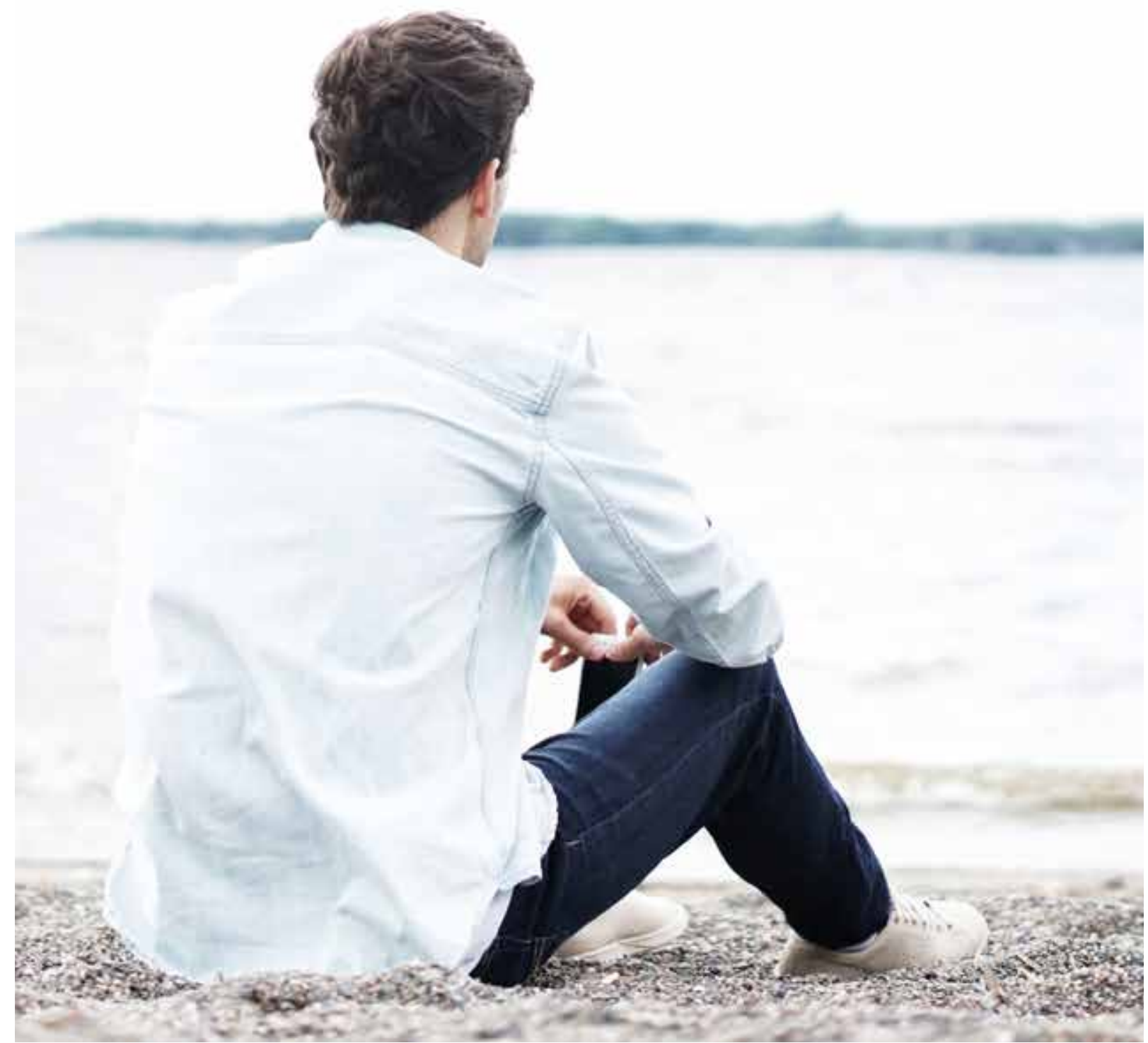




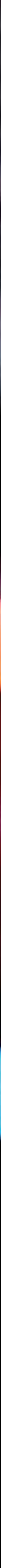




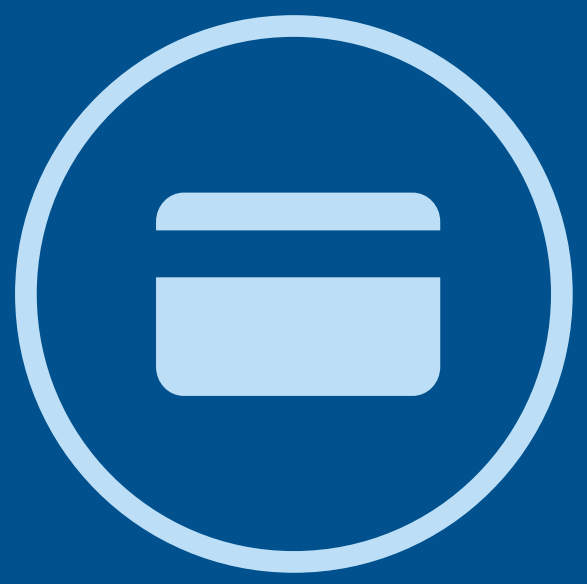

Hinder på skatteområdet 


\title{
Midlertidig import af heste mellem Norge og Sverige
}

\author{
Mange dyreejere oplever ofte store komplikationer, når de enten skal \\ føre deres heste over den norsk-svenske grænse for at løbe væddeløb \\ eller for at træne.
}

Ett prioriterat gränshinder av Svein Ludvigsen, Norge och Eva Tarselius-Hallgren, Sverige.

Prioriterat av Gränshinderrådet sedan 2017.

\section{Bakgrund}

Komplikationerne ved den midlertidige import og eksport mellem Norge og Sverige kan dels tilskrives:

- manglende informationer omkring værdisætningen af hestene

- en langsom håndtering af told-og momsafgifterne der opkræves ved grænsen

- en manglende viden hos dyreejerne om myndighedernes dokumentationskrav

- og en vens praksis for beregning af moms blandt toldregionerne.

\section{Konkret eksempel}

Det er forskelligt, hvilke konkrete komplikationer dyreejerne oplever, alt afhængig om hestene importeres til Norge eller Sverige. Følgende udfordringer er dog gennemgående.

\section{1) Håndtering af told og moms}

Selvom problemstillingen egentlig har forskellig karakter alt efter, om importen behandles i Sverige eller Norge, kan det overordnet konstateres, at vanskeligheder ved betaling af moms og depositum forekommer i begge lande. Eksempelvis kræver det norske Tollvesenet et depositumbeløb modsvarende momsen ved midlertidig indførsel af heste til Norge. I Sverige afkræves ligeledes en afgift i tolden svarende en procentdel af hestens/varens værdi, som er et tilgodehavende, og en sikkerhedsgaranti for at varen ikke importeres permanent. Beløbene betales tilbage, når ejeren/speditør fremviser dokumentation for indførsel og udførsel samt kvittering på depositummet. Problemet er dog, at sagsbehandlingstiderne er for lange. De kan strække sig fra én og op til flere måneder. Desuden kan der opstå yderligere komplikationer, hvis hesten føres frem og tilbage flere gange over grænsen inden for kort tid, da ejeren er nødt til at ligge flere beløb ud til depositum.

\section{2) Krav til identifikation og dokumentation af hestene (varen) \\ Mange dyreejere tilsyneladende ikke er klar over, hvilke dokumenter de behøver fremvise ved ind-og udførsel af deres heste. Oftest tror ejerne, at de kun skal fremvise en såkaldt "udførselsdeklaration", men derudover kræves det også, at de fremviser et helse- certifikat, som er udstedt af en offentlig dyrlæge, samt et hestepas for væddeløbsheste.}

\section{3) Vurdering af hestens/varens værdi}

Dyreejere har svært ved at vurdere den rigtige værdi af deres heste pga. manglende information fra myndigheder og en varierende praksis hos de forskellige toldregioner. I Norge pålægges det ejerne at vurdere og oplyse hestenes værdi ved tolden, hvoraf ejerne skal betale told og moms. I Sverige er det imidlertid praksis, at importafgiften beregnes ud fra hestens forsikringsværdi. Er hesten ikke forsikret, skal ejeren eller speditøren normalt betale et depositum på 10.000 kr. Derudover er desuden sådan i Norge, at hvis hesten trænes i landet og skal føres over til Sverige for at konkurrere i et løb, så anses hesten for at være "bearbejdet", hvilket betyder, at ejeren må betale "bearbejdsningsomkostninger" i tillæg til momsen. Som det står i lovgivningen, skal omkostningerne beregnes ud fra underholdsudgifter, dvs. udgift til 
træning, vaccination, stald, dyrlæge og lignende. Dog lader måden, hvorpå disse omkostninger beregnes, til at variere fra toldregion til toldregion i Norge. Det lader til, at ejerne til hestene intentionelt opgiver for en lav værdi for hesten, når de passerer tolden i Norge. Dette gør de for at mindske depositumsafgiften og for at undgå, at de har for store udlæg.

\section{4) Manglende eller fejlagtig information om forskellige regler og praksisser}

Dyrejerne oplever forskellig praksis, hvad angår betaling af told og moms i de forskellige toldregioner. Dette skyldes ifølge ejerne selv oftest for dårlig eller direkte fejlagtig information fra myndighedernes side. Desuden har de aktuelle interesseorganisationer også givet udtryk for, at de har svært ved at give korrekte oplysninger til deres medlemmer. Dvs. hesteejerne, de kommercielle stutterier, staldene og rideskolerne.

\section{Årsag}

Problemer relateret til midlertidig import af heste opstår pga. af landenes komplicerede momsregler, tvetydig praksis samt manglende information.

\section{Løsningsforslag}

Det foreslås, at Tollvesenet og Tullverket henholdsvis går igennem deres respektive regelværk og forsøger at forenkle eventuelt unødigt komplicerede regler; gør et forsøg for at forkorte behandlingstiderne; samt udarbejder en praksis, som er ens i alle toldregioner.

Derudover forslås det, at myndighederne gør en mere proaktiv indsats for at sprede viden om de eksiste- rende regler og praksisser blandt dyrejerne og deres interesseorganisationer, samt tilbyder assistance for opsøgende privatpersoner. Slutteligt forslås det, at de norske myndigheder ændrer deres praksis, sådan at vurderingen af den gældende værdi for en hest ligestilles med hestens forsikringsværdi, ligesom i Sverige.

Efter at have været i kontakt med de norske toldmyndigheder, er det kommet frem, at de aktører, som importerer deres heste midlertidigt, ofte drager paralleller til de forenklinger, som gælder for hundejere. Hunde behøver kun et hundepas for at kunne passere frit mellem den norsk-svenske grænse. Hesteejerne vil gerne have samme forenklinger for deres heste og sætter derfor spørgsmål ved den forskel, der gøres i håndteringen mellem hunde og heste.

\section{Gränshinderrådets arbete med frågan/ kommentarer från berörda regeringar}

Svein Ludvigsen, Norge:

Finansdepartementet og Tolletaten bekrefter at endel problemer oppstår pga manglende kunnskap om gjeldende regler. Tolletaten viser til sine internettsider som har detaljert informasjon om alle de problemstillinger som tas opp i sakspapirene vi har oversendt dem. De arrangerer årlig seminar som hestesportorganisasjonene deltar i.

Når det gjelder verdiansettelsen av hest er det komplisert, men forsikringsverdien et moment som tillegges vekt ved verdiansettelsen for tollklarering. 
Når det gjelder garantier for midlertidig innførsel for konkurranser, avl mv er det etablert garantiordninger hvor hesteorganisasjonene stiller selvskyldnergaranti. Dette er en ordning som gir rask og smidig grensepassering.

Det går sjelden mer enn 5 dager før Tolletaten har tilbakebetalt depositum som skal frigis.

Tolletaten er åpen for en dialog med sikte på å vurdere handteringen av utenlandske hester som innføres midlertidig til Norge for trening og som under treningsoppholdet i Norge deltar i konkurranser i utlandet.

Saken er i prosess i Grensehinderrådet i og med at vi avventer kommentarer på Finansdepartementets svar fra hestesportorganisasjonene.

Näringsdepartementet, Sverige:

I slutet på dokumentet ställs frågan om man inte skulle kunna skapa ett förenklat system för flyttning av hästar mellan SE och NO i likhet med vad som gäller för hundar.

Hundar som reser tillsammans med sina ägare i icke-kommersiella syften omfattas av ett förenklat EU-regelverk (jämfört med t.ex. handel med hundar). Enligt det förenklade systemet får hundarna medföras utan krav på veterinärintyg eller registrering $\mathrm{i}$ EU:s datasystem för djurförflyttningar (TRACES-systemet). Detta regleras i förordning 576/2013 om förflyttning av sällskapsdjur utan kommersiellt syfte.
Enligt EES-avtalet gäller förordning 576/2013 införsel av hundar från andra EU-länder till NO.

Något EU-regelverk motsvarande förordning

576/2013 finns inte för hästar som ju inte reser med sina ägare på semester etc. Att jämföra hästförflyttningar med hundförflyttningar bedöms därför inte som relevant.

I tulldelen är vi styrda av EU-reglerna. Frågan kretsar kring reglerna för tillfällig import och skyldigheten att ställa garanti. En hel del verkar gälla hanteringen i Norge och olikheter mellan tullregionerna, och det är ju en norsk angelägenhet. Vad gäller regelverket är det som vi konstaterat även i tidigare fall så att importmomsreglerna följer tullreglerna och dessa läggs i sin tur fast i EU-rätten. Det finns alltså inte något utrymme att bilateralt komma överens om mer långtgående förenklingar av regelverket.

Läs mer i Gränshinderdatabasen, granshinder.norden.org, gränshinder nr: 17-018. 


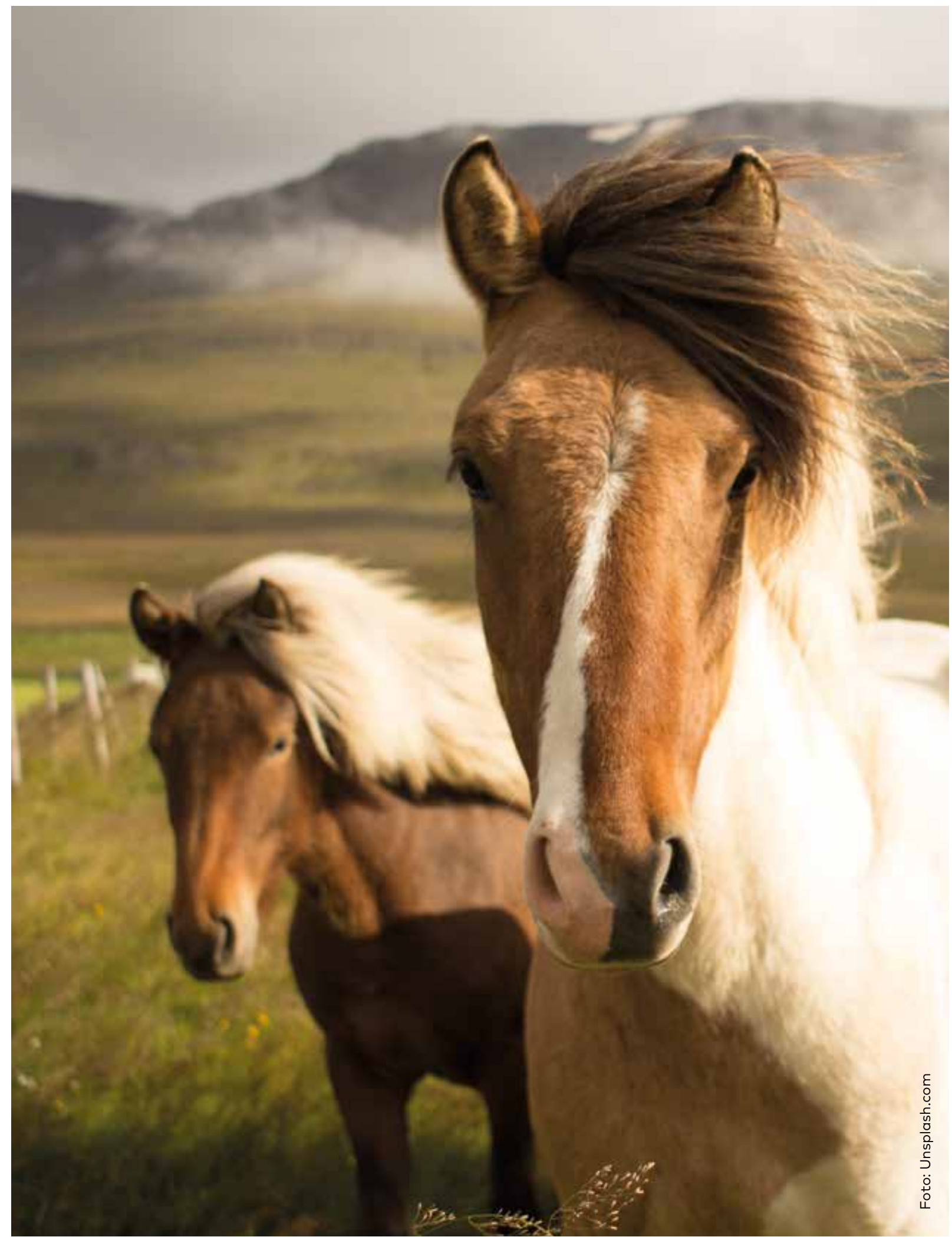




\title{
Norsk intern skattepraxis försvårar utförande av uppdrag i byggbranschen
}

\author{
Företag inom bygg- och anläggningsbranschen upplever stora administrativa \\ problem i samband med tillfälliga uppdrag i Norge. Detta även om uppdraget \\ endast varar några månader och är av engångskaraktär.
}

Ett prioriterat gränshinder av Svein Ludvigsen, Norge och Kim Andersen, Danmark.

Hindret kan lösas av Finansdepartementet i Norge.

Prioriterat av Gränshinderrådet sedan 2015.

\begin{abstract}
Bakgrund
Företagen upplever att de norska skattemyndigheterna administrerar utifrån interna norska regler och inte utifrån det nordiska skatteavtalet. För danska företag är konsekvensen att två av tre ger upp att ge sig in på den norska marknaden - antingen omedelbart eller inom det första året.

Principerna i det nordiska skatteavtalet innebär att exempelvis en dansk entreprenör som utför ett tillfälligt bygguppdrag blir skattepliktig i Norge först när det enskilda entreprenörsprojektet överstiger 12 månader. En tillfälligt utstationerad medarbetare blir skattepliktig först när han eller hon vistats längre än 183 dagar i landet under loppet av 12 månader. Dessa två viktiga regler i skatteavtalet ska främja den fria rörligheten i Norden.
\end{abstract}

Dessa två grundprinciper åsidosätts dock av intern norsk skattepraxis som gör att utstationerade tvingas ansöka om norskt skattekort från dag ett. Dessutom ska både företaget och den anställde lämna en norsk självdeklaration - även i de fall där det bara rör sig om ett enstaka kortvarigt projekt i Norge.

I EØS-regi afventes en udtalelse fra EFTAs overvågningsorgan (ESA), som i en åbningsskrivelse af 15. december 2016 har problematiseret oplysningspligtens forenelighed med servicedirektivet og tjenesteydelsernes fri bevægelighed. En sådan udtalelse er ikke retligt bindende, men såfremt udtalelsen indeholder anmærkninger, som den pågældende stat ikke retter sig efter, kan sagen indbringes for EFTA-Domstolen.

\section{Vem påverkas}

Företag som beger sig till Norge för att utföra uppdrag i byggbranschen.

\section{Gränshinderrådets arbete med frågan/ kommentarer från berörda regeringar \\ Svein Ludvigsen, Norge:}

Saken er tidligere avvist av Finansdepartementet, jfr Årsrapporten 2015. Etter at Danske Byggerier har konkretisert det de oppfatter som grensehinder har saken vært til fornyet vurdering i Finansdepartementet. Departementet uttaler at skatteplikten reguleres av norsk intern rett, ikke av skatteavtalen. Hindret lar seg ikke løse.

\section{Skatteministeriet, Danmark:}

Skatteministeriet har i nordisk kreds gjort opmærksom på, at oplysningspligten i den norske interne skattepraksis opleves som grænsehindrende for danske virksomheder og personer i bygge- og anlægsbranchen. Skatteministeriet har været i dialog med Dansk Byggeri, som har redegjort for de problemer, der opstår som følge af reglerne.

Skatteministeriet er opmærksom på, at en sag om oplysningspligtens forenelighed med tjenesteydelsernes fri bevægelighed verserer i EØS-regi.

Läs mer i Gränshinderdatabasen, granshinder.norden.org, gränshinder nr: 15-004. 

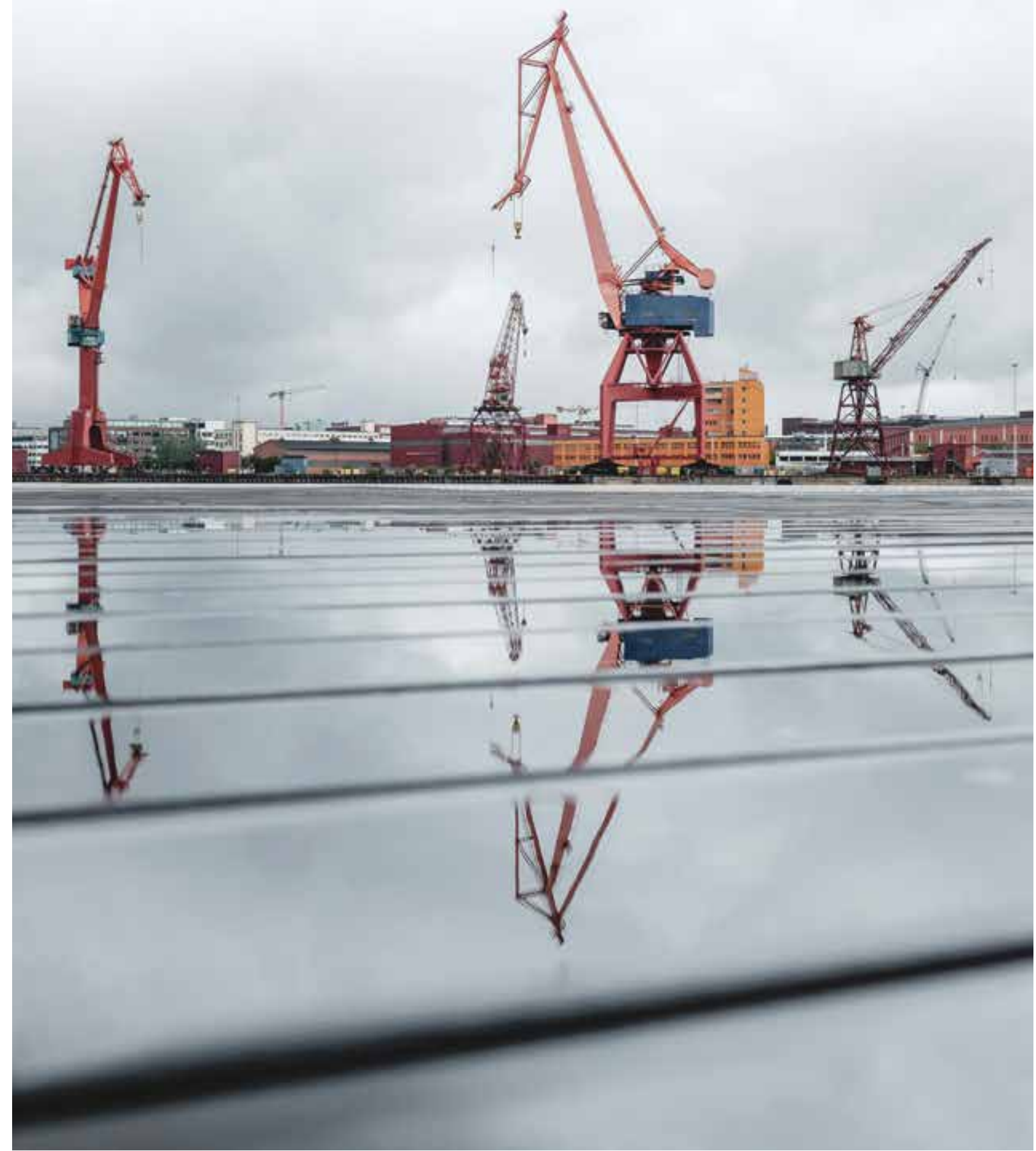


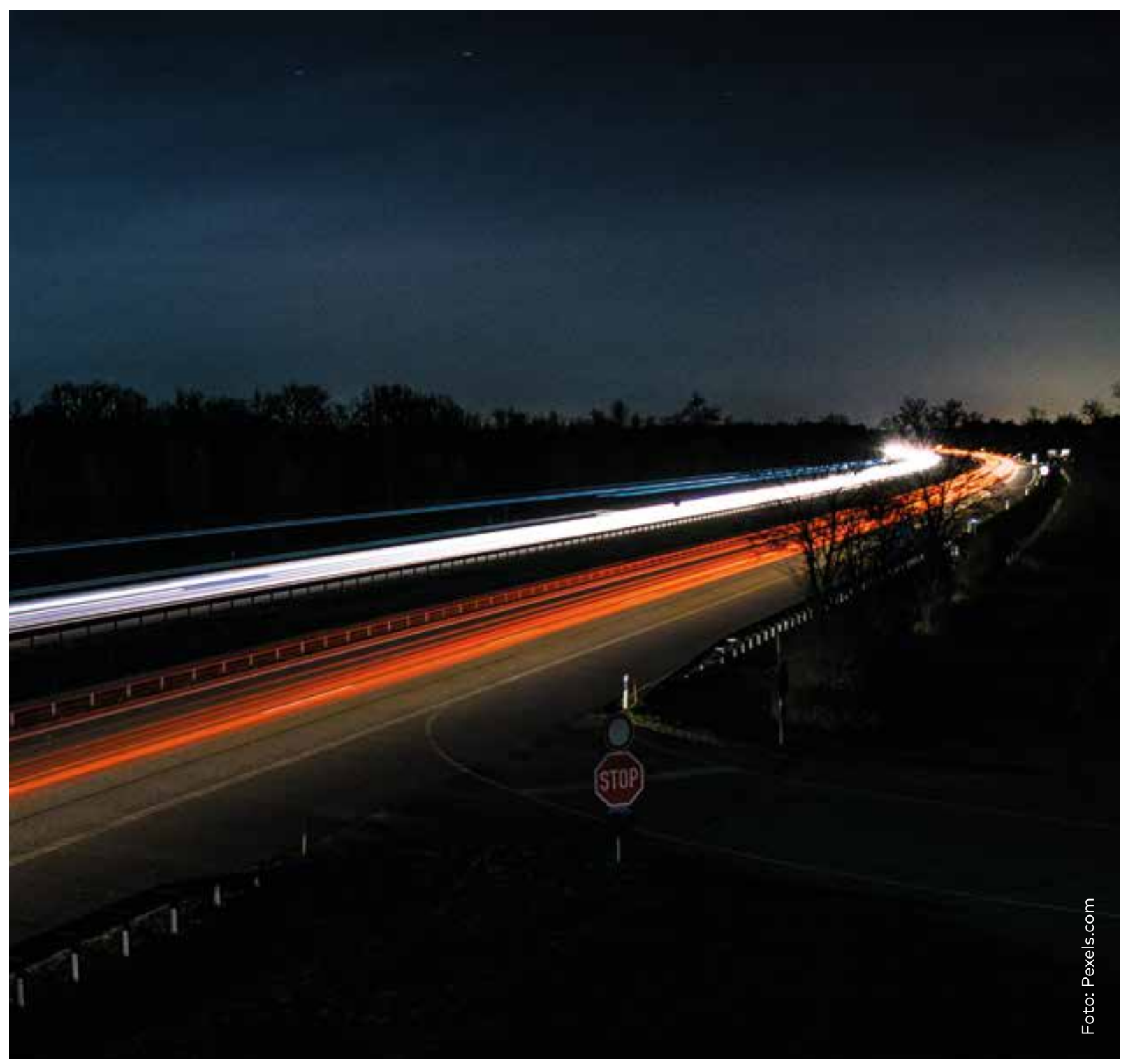




\title{
Vårdetransport över grånsen
}

\author{
De krav som enligt svenska regler ställs på finska värdetransportföretag och \\ dess anställda för att de ska kunna transportera Euro från handlare på den \\ svenska sidan av gränsen $i$ Torneå Haparanda innebär att företagen måste \\ göra extra investeringar $i$ utrustning och finansiera extra utbildningar för sina \\ anställda. Dessa krav hindrar i praktiken finska värdetransportföretag från \\ att hämta Euro från handlare på den svenska sidan av gränsen och leverera \\ dessa direkt till Finska banken.
}

Ett prioriterat gränshinder av Risto E.J. Penttilä, Finland.

Prioriterat av Gränshinderrådet sedan 2017.

\section{Bakgrund}

Haparanda och Torneå är livliga gränshandelscentrum där både Euro och svenska kronor används i handeln på båda sidor av gränsen. Handlarnas och bankernas hantering av de olika valutorna försvåras av att det föreligger vissa hinder för finska värdetransportföretag att hämta Euro direkt från svenska handlare och leverera dem till Finlands bank. De Euro som svenska handlare har mottagit som betalning måste istället växlas till svenska kronor och levereras till Finland genom Sveriges riksbank.

Finska värdetransportföretag kan bedriva verksamhet i Sverige, men för detta krävs enligt svensk lagstiftning att företaget är auktoriserat av svenska myndigheter. Med auktorisationen följer krav på att företaget följer de svenska regler som gäller för sådan verksamhet, bl.a. när det gäller utrustning.

Dessutom måste värdetransportföretagens personal enligt den svenska rikspolisstyrelsens föreskrifter genomgå en särskild utbildning för att kunna arbeta som väktare på den svenska sidan. Den som har genomgått sådan utbildning i ett annat EU-land måste få sina kvalifikationer godkända av Länsstyrelsen i Stockholms län för att kunna arbeta i Sverige. De krav som enligt svenska regler ställs på finska värdetransportföretag och dess anställda för att de ska kunna transportera Euro från handlare på den svenska sidan av gränsen i Torneå Haparanda innebär att företagen måste göra extra investeringar i utrustning och finansiera extra utbildningar för sina anställda.

Dessa krav hindrar i praktiken finska värdetransportföretag från att hämta Euro från handlare på den svenska sidan av gränsen och leverera dessa direkt till Finska banken.

Detta hinder har legat i gränshinderdatabasen som "löst" eftersom finska värde- transportföretag kan vara verksamma i Sverige med auktorisation. Hindret har dock lyfts på nytt med anledning av att de krav som ställs på finska värdetransportföretag och dess anställda för att de ska kunna vara verksamma i Sverige upplevs som ett hinder.

\section{Gränshinderrådets arbete med frågan/ kommentarer från berörda regeringar}

Risto E.J. Penttilä, Finland:

Saken i stort sätt avgjord, men kunde ännu göras smidigare.

Läs mer i Gränshinderdatabasen, granshinder.norden.org, gränshinder nr: 15-002. 


\title{
Tull och deposition i samband med överförsel av varor
}

\author{
Tullsvårigheter/problem uppmärksammas ofta i samband med tillfällig \\ införsel av varor till exempelvis Norge, då norska tullregler generellt \\ beskrivs vara förenade med mer administrativa bördor och fler avgifter \\ än vad man är van vid.
}

Ett prioriterat gränshinder av Risto E.J. Penttilä, Finland.

Prioriterat av Gränshinderrådet sedan 2017.

\begin{abstract}
Bakgrund
Generellt i alla länder gäller att de varor som förs in i ett land till försäljning är momsbelagda och i vissa fall även belagda med avgifter. Det är tullens uppgift att säkerställa att dessa pengar tillfaller den egna staten. EU och därmed Sverige har frihandelsavtal med de flesta länder, därmed ingen tull, men i vissa fall andra importavgifter. Områden som är belagda med avgifter handlar i Norges fall om t.ex. livsmedel, där det inhemska jordbruket främjas.
\end{abstract}

Problemet med depositioner har behandlats i en rapport från det svenska Kommerskollegiet:

Ett stort problem för många företag är att de måste deponera tull och moms, vanligtvis kontant, för varor som förs in i Norge trots att varorna ska återföras till Sverige. Det kan gälla såväl yrkesutrustning, arbetsmaterial, varuprover och mässmaterial. Pengarna återbetalas inom 90 dagar efter att varorna förts tillbaka över gränsen, men en administrativ avgift av det deponerade ursprungsbeloppet dras ofta av för varje månad varan finns i landet.

I Norge är avgiften 5 procent. Inom EU finns det gemensamma regler för mervärdesskatt vid köp över medlemsstaternas gränser och inga tullar, varför detta inte är ett problem vid handel mellan länder inom unionen.

För ett litet företag, till exempel en snickare med egen firma, kan det leda till ett likviditetsproblem att behöva ligga ute med större summor under längre tid, och kostnaden på 5 procent av beloppet kan vara kännbar. Det tar dessutom mycket tid i anspråk vid gränsen att beräkna momsen på en bil full med verktyg och material. I vissa fall gör kostnaden att det inte är lönsamt att ta uppdrag i Norge. Innan Sverige blev medlem i EU fanns tullfrihet mellan Sverige och Norge för servicebilar inklusive utrustning. Att nu moms och tull ska deponeras för all utrustning i snickarens bil gör det kostsamt. Snickaren måste också presentera följande fyra dokument, alla förenade med en kostnad, för att kunna göra en momsdeponering:

1. Vid utförsel ur Sverige: Exportdokument

2. Vid införsel i Norge: Importdeklaration

3. Vid återutförsel ur Norge: Importanmälan

4. Vid återinförsel i Sverige: Utförseldokument

Ett svenskt företag som inte är momsregistrerat i Norge får inte heller lov att sälja varor i Norge, och kan därför inte debitera den norska kunden moms-kostnaden. Snickaren kan alltså inte vidarefakturera kostnaden för moms som måste betalasför de varor som inte förs tillbaka till Sverige. 


\section{Lösningsförslag}

Det finns tre sätt att hantera moms vid tillfällig införsel av varor:

- Deponering av moms, som beskrivits ovan

- ATA-carnet

- Tullkredit, vilket kräver att importören är företagsregistrerad och momsregistrerad i Norge hos Brønnøysundregistrene. Sådan registrering utgör en hög tröskel för små företag som vill utföra mindre servicearbeten eller ta in små partier mässmaterial till Norge

Den bästa lösningen på snickarens problem borde alltså vara att använda en ATA-carnet. En ATA-carnet är ett internationellt tulldokument som låter innehavaren att tillfälligt (upp till ett år) importera varor utan att betala avgifter och skatter. Så länge som varorna återförs inom tidsramen så debiteras inga skatter eller avgifter. Det blir också enklare procedurer vid gränspassagen, inga av de fyra dokument som nämns ovan krävs. Syftet är att man ska kunna ta med sig varuprover och yrkesutrustning ut i världen utan att betala tull eller andra avgifter vid gränserna och slippa proceduren att återkräva skatter och avgifter från landets skattekontor. Systemet med ATA-carneter bygger på att den handelskammare som utfärdar dokumentet står som garant gentemot de länder som besöks, så som exempelvis Norge. Som säkerhet för handelskammarens garantiåtagande måste företaget deponera ett visst belopp till handelskammaren, som återbetalas när carneten återställs. En avgift tas också ut för varje ATA-carnet som utfärdas.
ATA-carnet kräver både administration och kapital eftersom en säkerhet ska ställas till handelskammaren. Avgifterna vid användande kan också bli betungande. Men även om ATA-carnet kräver både administration och kapital, kan det ofta vara en enklare och billigare lösning än den tulladministration och kostnad en deposition medför. ATA-carnetsystemet gäller dock inte för alla varor, vilket beskrivs närmare i nästa avsnitt.

En alternativ lösning för snickaren i exemplet ovan är kan också vara att bara ta med exakt det material som kommer att gå åt, ner till minsta skruv, för att slippa ligga ute med deponerad moms. Det är ett upplägg som dock inte så ofta är praktiskt genomförbart.

\section{Gränshinderrådets arbete med frågan/ kommentarer från berörda regeringar}

Risto E.J. Penttilä, Finland:

Frågan löst för redskapens del. Ännu öppen ifråga om mässvaror, hantverk och konstverk.

Läs mer i Gränshinderdatabasen, granshinder.norden.org, gränshinder nr: 14-062. 


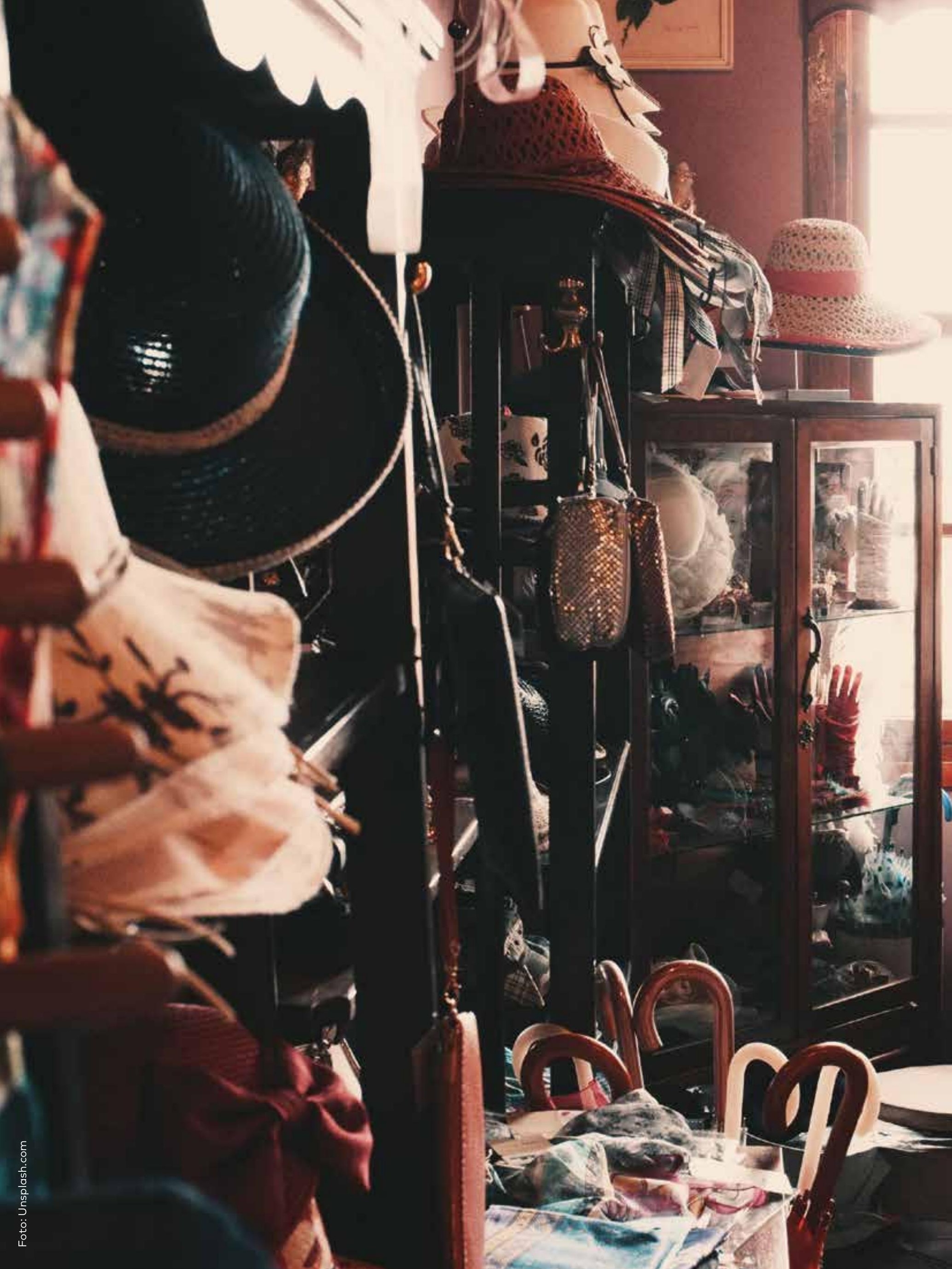




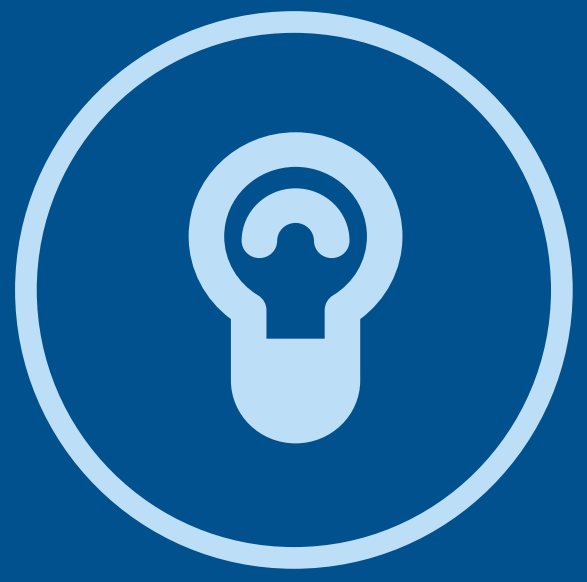

Hinder på nöringslivsområdet 


\section{Mobil livsmedelslokal som första ankomstplats i Finland}

Ett prioriterat gränshinder av Risto E.J. Penttilä, Finland, sedan 2017.

Prioriterat av Gränshinderrådet sedan 2014.

\section{Bakgrund}

En mobil livsmedelslokal kan på grund av ett beslut från det finska Livsmedelssäkerhetsverket Evira inte fungera som första ankomstplats för animaliska livsmedel som importeras till Finland. Detta begränsar möjligheten för svenska företag som vill sälja färska animaliska produkter från Sverige i Finland från till exempel en kylbil. När ett animaliskt livsmedel ankommer till Finland från ett annat EU-land, ska det först ankomma till en ankomstplats för inspektion. Som första ankomstplatser godkänns bland annat slakterier, köttstyckningsanläggningar eller förråd. Första ankomstplatser kan också vara livsmedelsaffärer, restauranger eller storkök.

En mobil livsmedelslokal är efter den finska Livsmedelslagen vilken som helst flyttbar eller temporär plats eller utrustning där livsmedel säljs eller hanteras. Det kan till exempel vara en flyttbar kiosk, en försäljningsvagn eller ett tält (Livsmedelslag 23/2006, 6§, 18a pkt.). Reglerna om livsmedelssäkerhet bygger i stor utsträckning på EU-förordningen 852/2004, men dylika krav rörande ankomstplatser ställs inte i förordningen. Danmark och Sverige ställer i övrigt heller inte sådana krav på specifika ankomstplatser för animaliska produkter importerade från andra EU-länder, utan hänvisar i lagstiftningen till EU-reglerna på området.

\section{Konkret exempel}

Det lilla företaget FISK Ab med huvudsäte i Pajala säljer färsk fisk från en kylbil i städer och byar på den svenska sidan av Tornedalen. Företaget vill gärna utöka sin kundbas, och önskar att kunna köra runt och sälja fisk på båda sidorna av gränsen. På grund av att man på den finska sidan inte godkänner mobila livsmedelslokaler, i detta tillfälle en kylbil, som första ankomstplatser, omöjliggörs det svenska företagets planer, då man inte har kapacitet att använda sig av till exempel ett slakteri som första ankomstplats i Finland.

\section{Förslag till lösning}

Det finska livsmedelssäkerhetsverket ändrar sin praxis så att man godkänner mobila lokaler som redan är registrerade och godkända i andra EU-länder. Som exempel står följande att finna i det svenska Livsmedelssäkerhetsverkets vägledning om godkännande av livsmedelsanläggningar från 2009, punkt 9.4.1: "Om en mobil anläggning är godkänd eller registrerad av en kontrollmyndighet $i$ ett annat land inom EU så motsvarar det en svensk registrering eller ett svenskt godkännande. Detsamma bör gälla länder inom EES, t.ex. Norge". Vidare borde en i utlandet godkänd mobil livsmedelslokal kunna användas som första ankomstplats för animaliska livsmedel i Finland.

\section{Gränshinderrådets arbete med frågan/ kommentarer från berörda regeringar}

Risto E.J. Penttilä, Finland:

Frågan väntas få en lösning i samband med en större förändring av livsmedelslagstiftningen.

Läs mer i Gränshinderdatabasen, granshinder.norden.org, gränshinder nr: 17-008. 


\section{Import af norske lakseyngel til Sverige}

Ett prioriterat gränshinder av Eva Tarselius-Hallgren, Sverige.

Prioriterat av Gränshinderrådet sedan 2014.

\section{Bakgrund}

Virksomheder, der gerne vil starte landbaserede laksebrug, kan til dags dato ikke importere lakseyngel fra hverken Norge eller Færøerne, da dette er forbudt ifølge svensk lov. Forbuddet hæmmer udviklingsmulighederne for det svenske, maritime erhvervsliv, da importen af norske lakseyngel ville kunne forøge sektorens konkurrenceevne.

Hindringen består i, at den eksisterende lovgivning ikke lader til at tage højde for produktionsforholdene for lukkede laksebrug på land, men hovedsageligt dækker åbne laksebrug ved havet. Lovgivningen beskytter mod spredningen af sygdom og lakselus til Sverige, som er udbredt blandt norske og færøske laks, men tager ikke hensyn til, at laksebrug på land er et lukket og selvforsynende produktionssystem. Denne form for produktionssystem har i modsætning til åbne havbrug en meget lav risiko for spredning af sygdom og lakselus.

Norge har i mange år forsket intensivt på området og anses for at have den bedst-egnede lakseyngel til laksebrug. Ved at forhindre importen af norske lakseyngel til produktion i lukkede brug forringes de svenske producenter konkurrenceevne væsentligt, sådan at de ikke kan konkurrere på lige fod med norske producenter på markedet.

\section{Konkret eksempel}

I Bohuslän, hvor fiskeri og forarbejdning af maritime levnedsmidler udgør størstedelen af kommunens erhvervsliv, vil man gerne anlægge et landbaseret fiskebrug. Hvert år importerer Sverige ca. 44.000 tons rensede laks fra Norge. Og ifølge Business Sweden svarer den norske laks, som importeres, forældes og videreeksporteres af Sverige, til en salgsværdi på ca. 20 milliarder. Derfor skønner en virksomhed, at landbaseret fiskebrug som en ny teknik kan vise sig at være en indbringende forretning både for kommunen og svensk erhvervsliv.
Virksomheden sætter sig for at udvikle et lukket, selvforsynende system, hvor restprodukterne fra fisken bl.a. skal anvendes til at drive et biogasanlæg. Energien fra biogasanlægget skal være med til at drive laksbruget som en del af det lukkede system. Det beregnes, at det planlagte laksebrug vil kunne producere ca. 4.000 tons laks om året. For at kunne starte laksebruget, vil virksomheden gerne købe norske lakseyngel, fordi man i Norge gennem intensiv forskning har udvundet en unik genetisk arvemasse, som anses for at være særligt egnede til denne form for fiskebrug. Den svenske lovgivning tillader dog ikke import af norske laks.

I stedet for norsk lakseyngel kunne virksomheden bruge lakseyngel fra svenske ferskvandssøer som kompensation. Dog har denne form for laks ikke den rette arvemasse og egner sig dermed ikke til storstillet produktion i lukkede brug på land.

\section{Förslag till lösning}

Det foreslås som løsning på hindringen, at de svenske myndigheder tilpasser lovgivningen, sådan at lukkede laksebrug på land ikke sidestilles med åbne havbrug.

\section{Gränshinderrådets arbete med frågan/ kommentarer från berörda regeringar} Näringsdepartementet, Sverige:

"Sveriges position är att åtgärden är berättigad med hänsyn till allmänna intresset att skydda djurhälsa. Åtgärden i fråga i form av tilläggsgarantier har införts $i$ Sverige med stöd av befintliga EU-regler (Kommissionens bes/ut (2010/221/EU) om godkännande av nationella åtgärder för att begränsa följderna av vissa sjukdomar hos vattenbruksdjur och vildlevande vattendjur $i$ enlighet med artikel 43 i rådets direktiv 2006/88/EG). Åtgärden har anmälts och godkänts av EU-kommissionen."

Läs mer i Gränshinderdatabasen, granshinder.norden.org, gränshinder nr: 17-020. 


\title{
Färöiska färdskrivarkort
}

\section{Färöiska yrkeschaufförer upplever problem med att få utställt digitala färdskrivarkort på Färöarna (tachografer). Chauffören kan därför inte registrera sin körtid i enlighet med de regler som gäller i Danmark och de övriga nordiska länderna.}

\author{
Ett prioriterat gränshinder av John Johannessen, Färöarna. \\ Hindret kan lösas vid samarbete mellan Danmark och Färöarna. \\ Prioriterat av Gränshinderrådet sedan 2014.
}

\section{Bakgrund}

Det så kallade AETR-avtalet (European Agreement concerning the Work of Crews of Vehicles Engaged in International Road Transport) innehåller regler om internationell yrkestrafik. Enligt avtalet ska yrkeschaufförer registrera sin körtid med en digital färdskrivare.

För parter som inte skrivit under avtalet, bland annat Färöarna, finns dock en möjlighet att fortsättningsvis använda färdskrivarkort som fylls i för hand.

Nya fordon är dock i regel endast utrustade med en digital färdskrivare, vilket innebär att chauffören måste få tillgång till ett digitalt färdskrivarkort. Det finns på Färöarna ingen myndighet som kan utställa sådana digitala färdskrivarkort.

Det innebär i sin tur att en färöisk yrkeschaufför stöter på problem då hon/han kommer över till Danmark, eller något av de andra nordiska länderna, eftersom bristen på ett digitalt färdskrivarkort gör att det inte är möjligt att registrera körtiden enligt gällande regler.

\section{Vem påverkas}

Färöiska chaufförer, både de som kör i yrkesmässig trafik som större bussar och transporter samt de som kör akuttransporter/nödhjälp.

\section{Förslag till lösning}

- Färöarna ansluter sig till AETR-avtalet, om det är möjligt.

- Möjligheten öppnas för att utfärda digitala färdskrivare.

- Färöarna utser en myndighet som kan utställa digitala färdskrivarkort.

\section{Gränshinderrådets arbete med frågan/ kommentarer från berörda regeringar}

Bemærkninger fra landsstyreområdet for infrastruktur, Færøerne:

Der arbejdes i øjeblikket på en løsning på sagen. Landsstyreområdet har fået oplyst fra Transport-, Bygnings- og Boligministeriet i Danmark, at de arbejder med at finde ud af, om det er nødvendigt at lave ændringer i færdselsloven eller ikke. Landsstyreområdet hører nærmere om dette snarest.

Landsstyreområdet har i denne forbindelse gjort opmærksom på, at denne sag skal løses snarest muligt og inden sæsonen for kørsel med færøske busser i Danmark starter i marts/april 2018.

Läs mer i gränshinderdatabasen, granshinder.norden.org, gränshinder nr: 14-152. 


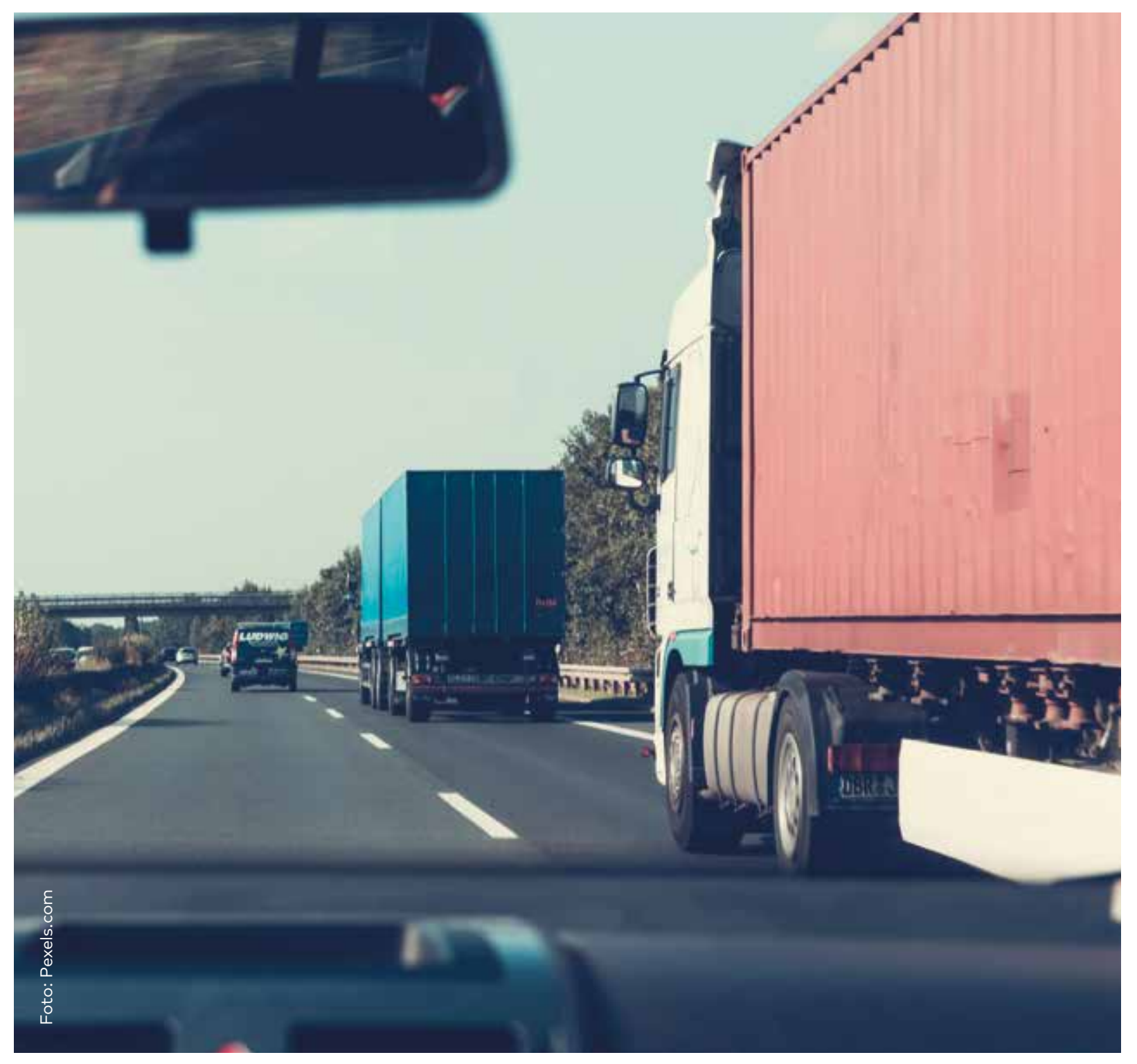




\title{
Olika byggbeståmmelser
}

\section{De nordiska ländernas krav på byggmaterial skiljer sig åt, vilket försvårar entreprenörernas verksamhet och hämmar handeln över gränser.}

\author{
Ett gränshinder som prioriteras av Risto E.J. Penttilä, Finland, Gunnar Westerholm, Åland och \\ Kim Andersen, Danmark.
}

Hindret ingår i avtalet från 2013 mellan den danska regeringen och samtliga partier i det danska Folketinget om att avlägsna gränshinder i Norden.

Prioriterat av Gränshinderrådet sedan 2014.

\section{Bakgrund}

Olika byggbestämmelser gör det svårt för företag som är verksamma i ett land att röra sig över gränserna. Det har en negativ effekt på konkurrensen och gör det svårt att utveckla den nordiska gemensamma hemmamarknaden. Gränshindret är i sig mycket brett och består av en rad problemställningar som rör bland annat VVS-området, elinstallationer, brandoch bullerskydd samt klassificering och certifiering av dessa.

En bidragande faktor är att många av byggbestämmelserna sätts av ländernas branschorganisationer, något som gör det svårt att angripa problemet genom lagstiftning. I den mån det finns offentlig reglering finns det i sin tur skillnader i de nivåer som bestämmelserna sätts på. I Sverige finns regleringen till exempel på lag-, förordnings- och myndighetsnivå. I Finland kan byggbestämmelserna variera mellan olika kommuner. Därutöver finns olika rekommendationer, råd och frivilliga standarder med olika juridisk status beroende på vilket land det är fråga om. Rent konkret kan det röra sig om skillnader i kraven gällande exempelvis tröskelhöjder, bullerskyddsnivåer och virkesdimensioner.

Skillnaderna mellan länderna gör det förståeligt att det är svårt för mindre företag och småhusleverantörer att anpassa sin produktion till alla de olika kraven och standarderna. En del av problemen löses visserligen på europeisk nivå, men det finns stor potential för de nordiska länderna att fungera som föregångare och skapa gemensamma bestämmelser. Det gäller i synnerhet utarbetandet av helt nya byggregler. En större grad av harmonisering skulle skapa en större marknad för alla entreprenörer i Norden och på sikt bidra till en lägre prisnivå för konsumenterna.

\section{Förslag till lösning}

Ett visst problemområde, exempelvis brand- och bullerskydd, görs till pilotprojekt för att utarbeta gemensamma nordiska byggbestämmelser. Erfarenheterna kan sedan användas för att harmonisera andra bestämmelser.

\section{Gränshinderrådets arbete med frågan/ kommentarer från berörda regeringar} Transport, Bygnings- og Boligministeriet, Danmark Den fortsatte udvikling mod flere harmoniserede standarder og brugen af flere fælleseuropæiske standarder i den danske regulering af byggeområdet bidrager til at gøre det danske byggemarked til et mere åbent marked med bedre konkurrencevilkår for branchens nationale og internationale aktører, hvilket også gælder aktører fra de øvrige nordiske lande. Danske byggeregler er generelt fleksible, da bygningsreglementet overvejende er baseret på funktionskrav som gør det lettere for udenlandske byggevirksomheder at konkurrere på det danske marked.

Gunnar Westerholm, Åland:

Ålands landskapsregering förespråkar att det arbete som pågår mellan Nordens nationella byggmyndigheter intensifieras för att uppnå samförstånd och likhet mellan omotiverade skillnader i regelverken. Om skillnader utgör ett gränshinder eller mer handlar om en 


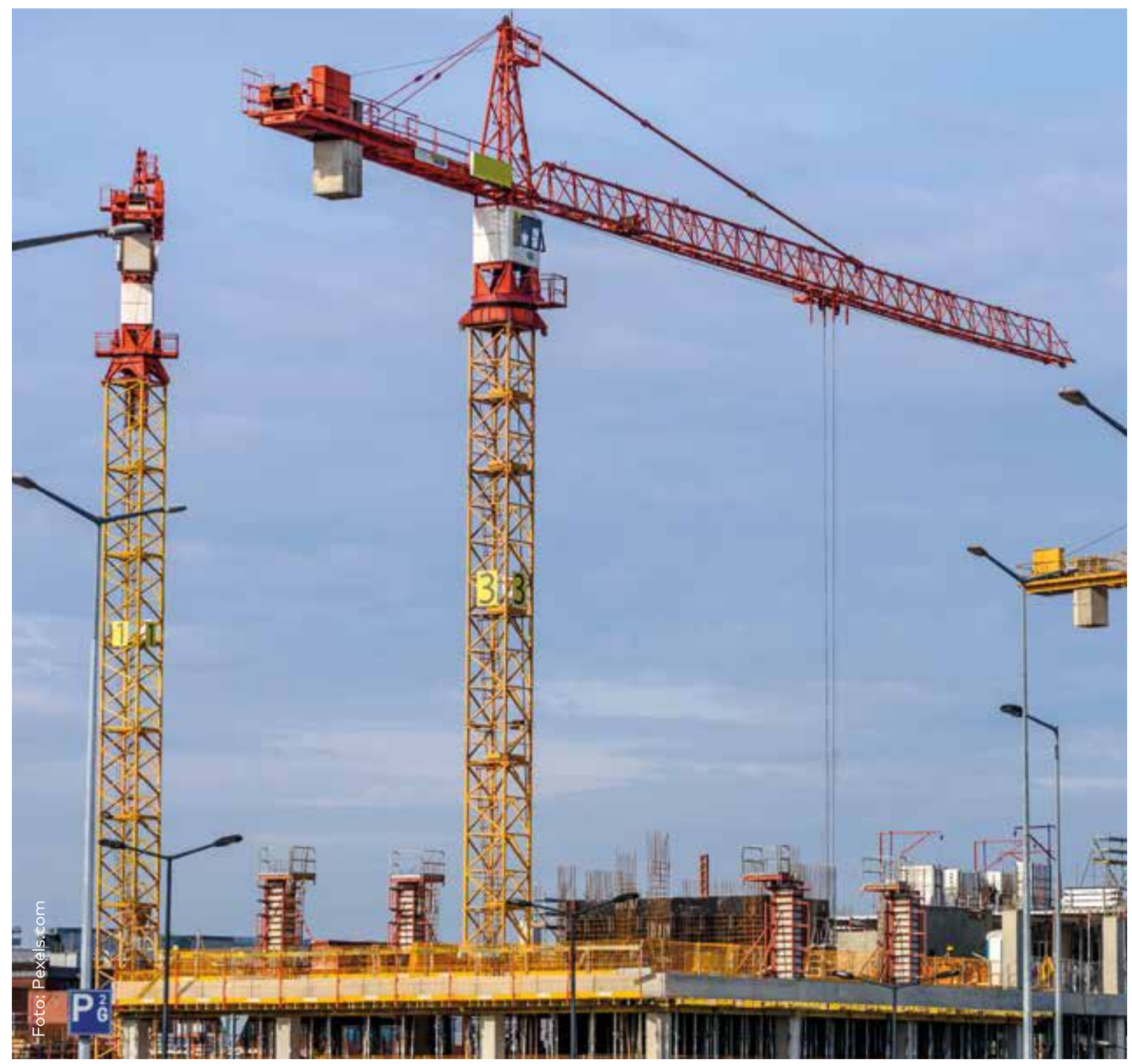

anpassning av verksamheten för gränsöverskridande byggföretag är inte heller lättdefinierad. Svenska Boverket har varit ledande i det nordiska samarbetet mellan myndigheterna varför det vore mest ändamålsenligt att svenska regeringen upprätthåller kontakten med Boverket för att få ett klargörande av situationen.
Risto E.J. Penttilä, Finland:

Vid diskussioner med finländska parter har noterats intresse. Nu inväntas resultat från Sverigeledda nordiska arbetsgrupper.

Läs mer i gränshinderdatabasen,

granshinder.norden.org, gränshinder nr: 14-076. 


\title{
Brist på samlad information för små och medelstora företag om att bedriva verksamhet $\mathrm{i}$ andra nordiska länder
}

\author{
Det är svårt för små och medelstora nordiska företag att få en samlad \\ information om vilka lagar och regler som gäller för att bedriva verksamhet \\ om ett annat nordiskt land.
}

Ett prioriterat hinder av Risto E.J. Penttilä, Finland och Dagfinn Høybråten, Nordiska ministerrådet.

Detta är ett av de 15 gränshinder som prioriterades av arbetsmarknadens parter i Norden vid näringslivskonferensen på Børsen i Köpenhamn den 30 april 2015.

Prioriterat av Gränshinderrådet sedan 2016.

\section{Bakgrund \\ På några områden är det en barriär i sig att de lagar och regler som gäller i de nordiska länderna för små och medelstora företag inte är överblickbara. Detta gäller företag som vill bedriva sin verksamhet över gränserna genom att etablera sig i ett annat land, bedriva handel över gränsen eller anställa personal som bor i andra nordiska länder. Frågorna gäller t.ex. information om registringskrav, särskilda krav gällan- de godkännande av produkter, var beskattning ska ske och var medarbetare ska vara socialförsäkrade. \\ Problemet kan både bestå i att informationen inte är tillräckligt tydlig eller att det inte är klart vem det är som tillhandahåller den. Företag och arbetstagare hänvisas ofta från den ena till den andra myndighe- ten. Ibland är svarstiden lång eller kostnadskrävande då företagen måste anlita konsulter eller advokater för att få klarhet över vilka regler som gäller.}

I Norden finns i nuläget flera olika informationstjänster för företag och enskilda på detta område. För medarbetare som vill arbeta i ett annat nordiskt land finns Hallå Norden som lämnar information om förhållandena i samtliga nordiska länder samt Åland, Färöarna och Grönland.
Den regionala informationstjänsten $\varnothing$ resunddirekt ger information via webb, informationskontor, telefon och mail till svenska och danska privatpersoner som vill arbetspendla mellan Sverige och Danmark. $\varnothing$ sunddirekt Business ger information till svenska och danska företag som vill rekrytera personal från grannlandet, etablera företag i grannlandet eller köpa eller sälja varor i grannlandet. Informationskontoret i Malmö ger även information en gång i veckan till företag som söker information.

Grensetjänsten lämnar information via webb, informationskontor, telefon och mail till svenska och norska privatpersoner som vill arbetspendla mellan Sverige och Norge. Grensetjänsten har idag även information till svenska och norska företag på såväl webb som genom informationskontor. Under hösten startades ett treårigt Interregprojekt som ska underlätta företags gränsöverskridande verksamhet längs hela den norsk-svenska gränsen. I detta arbete kommer även gränshinder för näringslivet att kartläggas.

Nordkalottens gränstjänst ger information via webb, informationskontor, telefon och mail till svenska, finska och norska privatpersoner som vill arbetspendla mellan Sverige, Finland och Norge. De förmedlar idag även näringslivsinformation via webb och genom sina informationskontor. Under hösten har man påbörjat 


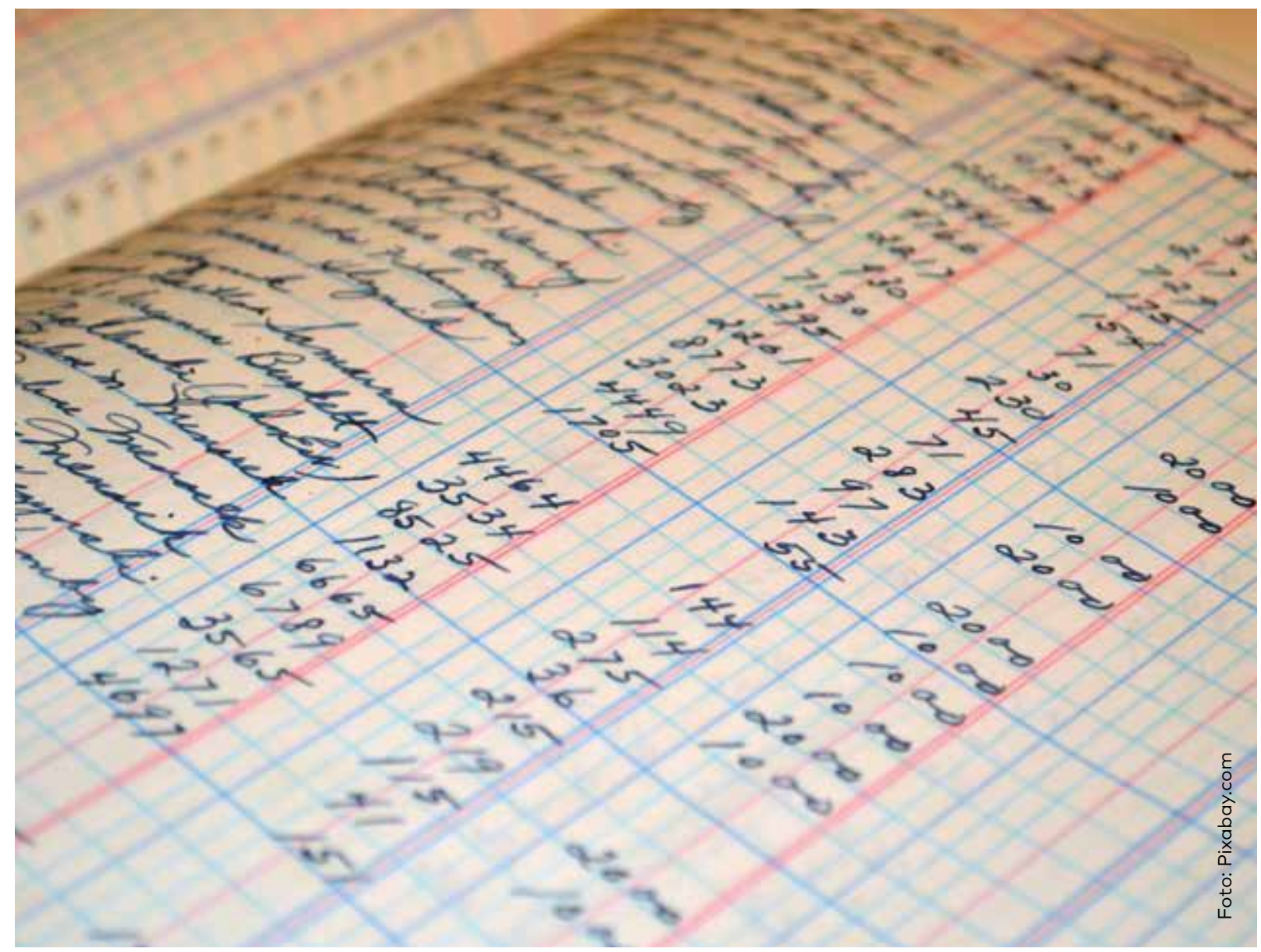

ett treårigt Interregprojekt i syfte att stärka Gränstjänstens näringslivsservice och underlätta näringslivssamarbetet mellan länderna.

Dessa tjänster finansieras helt eller delvis av Nordiska ministerrådet.

\section{Gränshinderrådets arbete med frågan/ kommentarer från berörda regeringar}

\section{Gränshinderrådets sekretariat:}

Under 2017 har en länkportal för näringslivet i Norden färdigställts, Nordenbusiness.org. Portalen har presenterats för arbetsmarkandens parter vid de åtta nationella dialogmötena. Parterna ställer sig positiva till portalen och önskar bidra med att synliggöra den nationellt.
Under 2018 kommer Nordiska ministerrådet satsa på en ökad synlighet av portalen i Norden. Utifrån resultatet av besöksstatistik kommer portalen att utvärderas och vidareutvecklas. 
$\rightarrow 2 y+2=$

wothens?

$320^{6}-5056=$

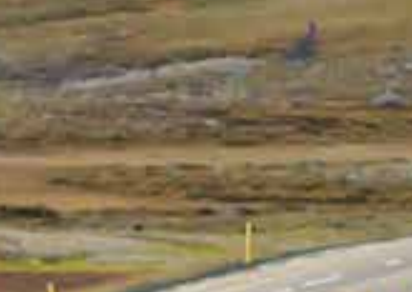

$-1,+20$

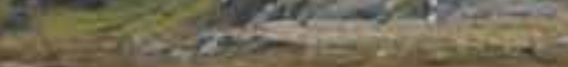

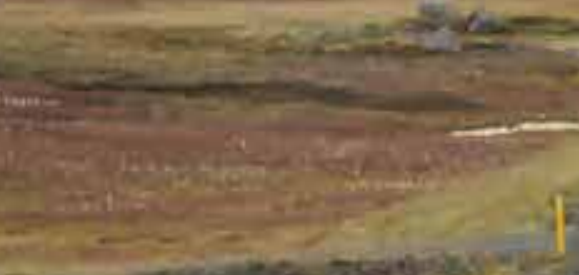

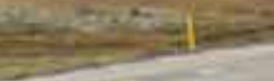

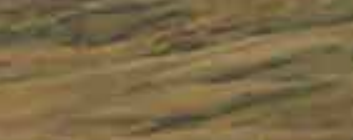

$-x^{2}-1=$
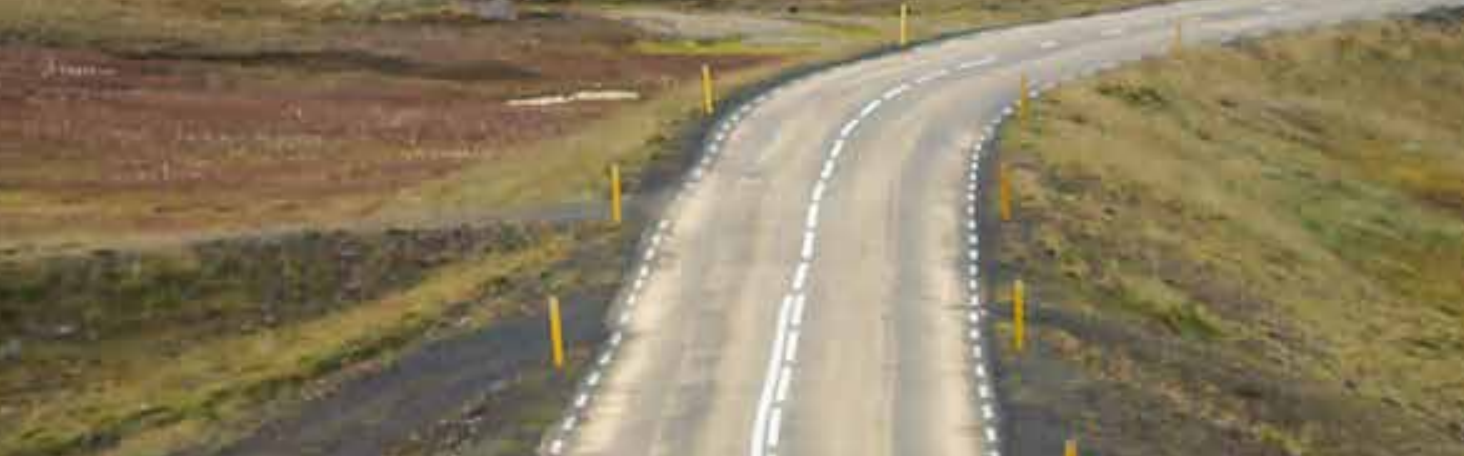

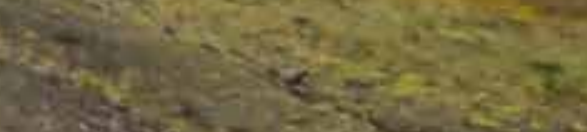

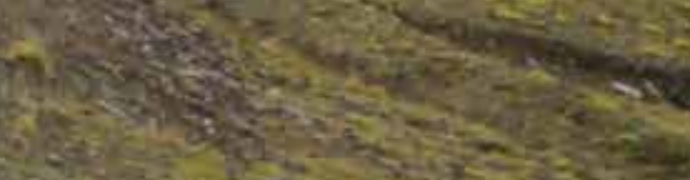


Övriga gränshinder 


\title{
Samordningsnummer till utländska fritidshusågare i Sverige
}

\author{
Utländska fritidshusägare i Sverige upplever problem med att teckna \\ el-, tele- och internetavtal på grund av att de varken har personnummer \\ eller samordningsnummer.
}

Ett prioriterat gränshinder av Eva Tarselius Hallgren, Sverige.

Hindret kan lösas av det svenska Finansdepartementet (dock ej helt då samordningsnummer inte ersätter personnummer i alla avseenden).

Prioriterat av Gränshinderrådet sedan 2014.

\section{Bakgrund}

Även om problemet rör en begränsad grupp av människor så visar detta ändå tydligt vilka konsekvenser avsaknaden av ett personnummer har. Det gäller i synnerhet i Sverige där systemen för service, tjänster och handel är uppbyggt på personnummer. För betalning av fastighetsavgift m.m. får utländska fritidshusägare ett så kallat GD-nummer som de använder i kontakt med Skatteverket. Detta nummer har ingen spridning i samhället i övrigt.

Numret fyller i stort sett ingen funktion i kontakt med privata aktörer, vilket leder till problem vid tecknandet av exempel- vis el-, tele- och internetavtal. Utländska fritidshusägare har därför behov av att få ett så kallat samordningsnummer, som får spridning i samhället genom Statens personadressregister, SPAR.

\section{Vem påverkas}

Utländska fritidshusägare i Sverige, totalt cirka 36500 personer, varav ungefär 22500 kommer från Danmark, Norge eller Finland, påverkas. Av dessa har $78 \%$, omkring 28700 personer, uppgett att de har behov av ett samordningsnummer enligt Øresundsinstituttets beräkningar.

\section{Ekonomiska konsekvenser}

Enligt en utredning gjord av svenska Skatteverket år 2014 kostar det cirka 19 miljoner SEK, en engångsinvestering, att byta ut de existerande GD-nummer, som är registrerade för utländska fastighetsägare, till samordningsnummer. Därutöver tillkommer utvecklingskostnader. Den årliga besparingen av att GD-nummer som används för utländska fastighetsägare byts ut värderas enligt samma utredning till 270000 SEK enligt Skatteverkets beräkningar.

Om hälften av de utländska fritidshusägarna som uppgett att de har behov av ett samordningsnummer skulle teckna ett TV-abonnemang till 269 SEK/ månad, skulle de bidra till att öka omsättningen för TV-abonnemang med ungefär 46 miljoner SEK. Närmare beräkningar finns nedan.

\section{Förslag till lösning}

Samordningsnummer ska även tilldelas utländska fritidshusägare.

\section{Gränshinderrådets arbete med frågan/ kommentarer från berörda regeringar}

Finansdepartementet, Sverige:

Finansdepartementets arbete med frågan om samordningsnummer till utländska fastighetsägare kräver fortsatt dialog med Skatteverket och Lantmäteriet. Finansdepartementet arbetar även vidare med nödvändiga författningsändringar och med frågan hur finansieringen ska lösas.

Läs mer i Gränshinderdatabasen, granshinder.norden.org, gränshinder nr: 14-160. 


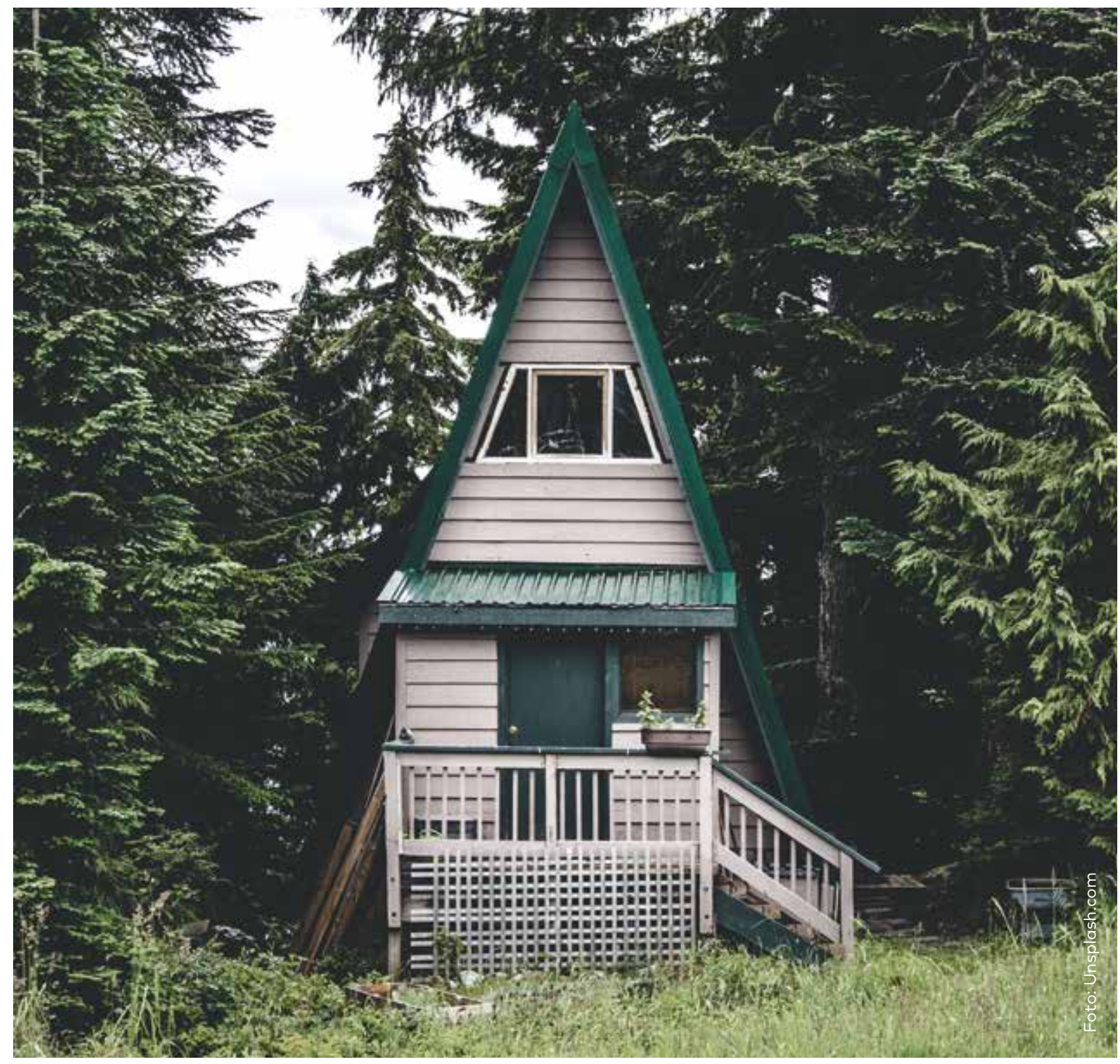

\section{Øresundsinstittutets beräkningar}

Antal utländska fritidshusägare i Sverige

Norrmän

Finländare

Danskar

Övriga

Andel som är i behov av samordningsnummer $=78 \%$

Hälften av dessa tecknar ett TV-avtal (beräknat för Boxer Mix)

Kostnad för TV-avtal/månad
36761 personer

11605 personer

235 personer

11605 personer

13316 personer

28674 personer

14337 personer

269 SEK

Total årlig utgift för utländska fritidshusägare, enbart för TV-avtal

46279158 SEK

Kostnad för att införa samordningsnummer

19000000 SEK 


\section{Erkännande av färöiska körkort}

\section{Färöiska körkort kan inte bytas ut i alla de nordiska länderna då en person flyttar till ett annat nordiskt land.}

Ett prioriterat gränshinder av John Johannessen, Färöarna.

Prioriterat av Gränshinderrådet sedan 2014.

\section{Bakgrund}

När en person bosätter sig i ett nordiskt land ska gällande körkort bytas ut till bosättningslandets. Färöiska körkort kan inte bytas ut i alla nordiska länder. I Sverige och i Finland betraktas det färöiska körkortet som utgivet i ett land som inte är medlem av EU och kan därför inte bytas ut mot det svenska eller det finska.

Färöarna omfattas inte av överenskommelsen gjord den 12 november 1985 mellan Danmark, Finland, Sverige och Norge om gemensamt godkännande av körkort och registrering av fordon och det är inte möjligt att ansluta till överenskommelsen vid nuvarande tidpunkt. Det har funnits överväganden om att göra en revision av överenskommelsen i nordisk regi, men detta har lämnats utan åtgärd, då de områden som överenskommelsen omfattar, till stor del regleras av EU-regler, inklusive EU:s körkortsregler. Färöarna är varken medlem av EU eller EES.

Det är möjligt att byta ut det färöiska körkortet mot ett danskt, norskt, isländskt och brittiskt. Detta kan innebära att innehavaren av ett färöiskt körkort tvingas mellanemigrera till ett av dessa länder för att kunna byta ut sina körkort vid bosättning i Sverige eller Finland.

Det finns inga trafiksäkerhetsmässiga aspekter att beakta vid utbyte av körkort. Färöarna har till stor del implementerat körkortsdirektivet i färöisk lagstiftning.

\section{Förslag till lösning}

De länder som idag inte har behörighet att ersätta det färöiska körkortet skulle kunna se över gällande regler för en bedömning av möjligheten att byta kör- kort på samma villkor som för medborgare i övriga Norden och i EU/EES-länderna.

\section{Vem påverkas}

Personer med färöiska körkort kommer att påverkas. Det är svårt att säga hur många, då det antas att en del av dessa i dag väljer att mellanemigrera. Oavsett hur många personer det rör sig om är det viktigt för enskilda personer som drabbas. De flesta personer bör kunna byta ut det färöiska körkortet mot ett nytt som uppfyller EU:s krav/regler.

\section{Gränshinderrådets arbete med frågan/ kommentarer från berörda regeringar}

Bemærkninger fra landsstyreområdet for trafikanliggender, Færøerne:

Status er, at der ikke har været nogen udvikling i sagen. Det færøske kørekort kan hverken ombyttes med svensk eller finsk kørekort. Det havde været ønskeligt at få løst problemet hurtigt muligt, fordi både Norge, Danmark, Island og Storbritannien godkender det færøske kørekort og laver ombytte uden problemer.

Näringsdepartementet, Sverige:

Att erkänna körkort från Färörna som likställt med körkort utfärdat i EES, och godta utbyte utan förarprov kräver ändring i körkortslagen (1998:488) och är en relativt tidskrävande process, det saknas $\mathrm{i}$ dag ett underlag med översikt dels hur många som berörs, och dels en utvärdering av körkortsregelverk och trafiksäkerhetsaspekter av det färöiska förarutbildningssystemet, det är ej heller fastställt huruvida Färöarna byter ut tredje länders körkort. Ärendet bereds för närvarande i regeringskansliet.

Läs mer i gränshinderdatabasen, granshinder.norden.org, gränshinder nr: 14-128. 


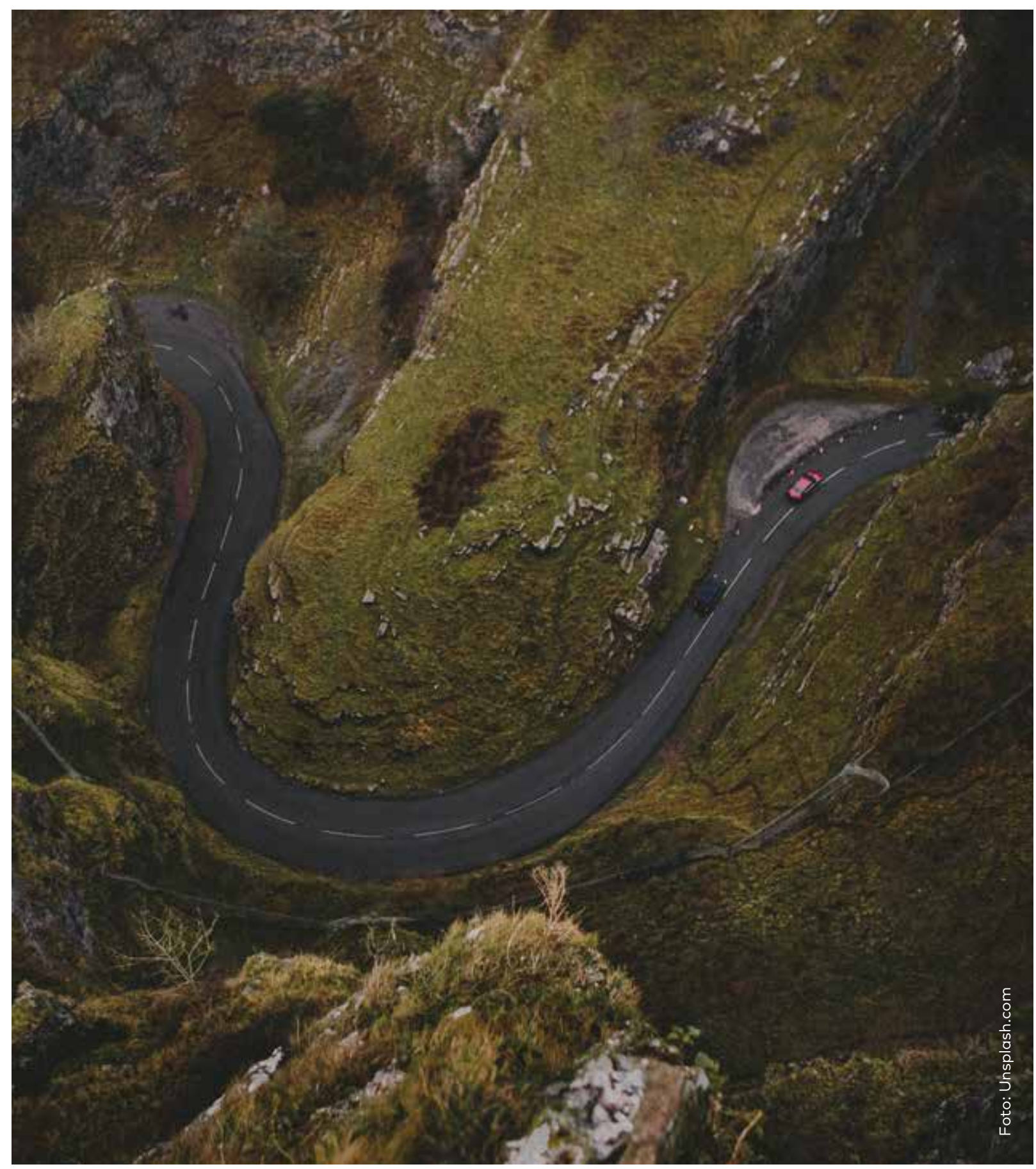




\title{
Erkånnande av grönländska körkort
}

\author{
Grönländska körkort kan inte bytas ut i alla de nordiska länderna då \\ en person flyttar till ett annat nordiskt land.
}

Ett prioriterat gränshinder av Jørgen S. Søndergaard, Grönland.

Hindret kan lösas av Rigspolitiet, Danmark.

Prioriterat av Gränshinderrådet sedan 2014.

\section{Bakgrund}

Den som reser till Danmark med sitt grönländska körkort, kan använda det i 90 dagar, därefter måste personen göra ett körprov. Detta körprov kan anses vara irrelevant om personen redan har kört i 90 dagar.

Olika regler gäller för körkort från respektive Färöarna och Grönland i de nordiska länderna. De regler som gäller för Grönland är ofta strängare än de regler som gäller för Färöarna. Du kan använda det färöiska körkortet i Danmark utan att behöva byta ut kortet, eller betala för körprov.

\section{Vem påverkas}

Ett svar förväntades från Rigspolitiet om hur många grönländska körkort som bytts ut det senaste året, samt hur stor misslyckandeprocenten är för körprovet i detta sammanhang. Rigspolititet har meddelat att man inte för någon statistik.

\section{Ekonomiska konsekvenser}

Den som berörs av detta hinder har följande utgifter:

- 280 DKK för utbyte av körkort

- 890 DKK för körprov

- Hyra av godkänt fordon till körprovet

- Eventuella extra körtimmar

\section{Förslag till lösning}

Ändring av den danska körkortsförordningen så att samma villkor gäller för grönländska körkort som nu gäller för färöiska.

Revision av överenskommelse från den 12 december 1985 som gäller ömsesidigt erkännande av körkort etc.
Andra länder som särskilt nämner Grönland i sin lagstiftning (exempelvis Norge), kan behöva ändra sin lagstiftning.

\section{Gränshinderrådets arbete med frågan/ kommentarer från berörda regeringar}

Jørgen S. Søndergaard, Grønland:

Der er nu forhandlinger i gang mellem de grønlandske og danske myndigheder og sagen har været bragt op politisk med et $\S 37$ spørgsmål fra Inatsisartut. Det grønlandske parlament. I sit svar til medlem af Inatsisartut Michael Rosing oplyser Naalakkersuissoq for Kommuner, Bygder, Yderdistrikter, Infrastruktur og Boliger Erik Jensen at man har etableret en arbejdsgruppe med Transport- Bygnings- og Boligministeriet i Danmark samt Grønlands Politi, som skal komme med forslag til løsninger på en række af de spørgsmål som i øjeblikket er rejst. Det oplyses i svaret til medlem af Inatsisartut Michael Rosing, at en løsning på de rejste spørgsmål sandsynligvis vil kræve en ændring af kørekortbekendtgørelsen og muligvis en ændring af Færdselslov for Grønland. Grænsehindringsrådet afventer resultatet af forhandlingerne mellem sagen parter.

Läs mer i gränshinderdatabasen, granshinder.norden.org, gränshinder nr. 14-172. 


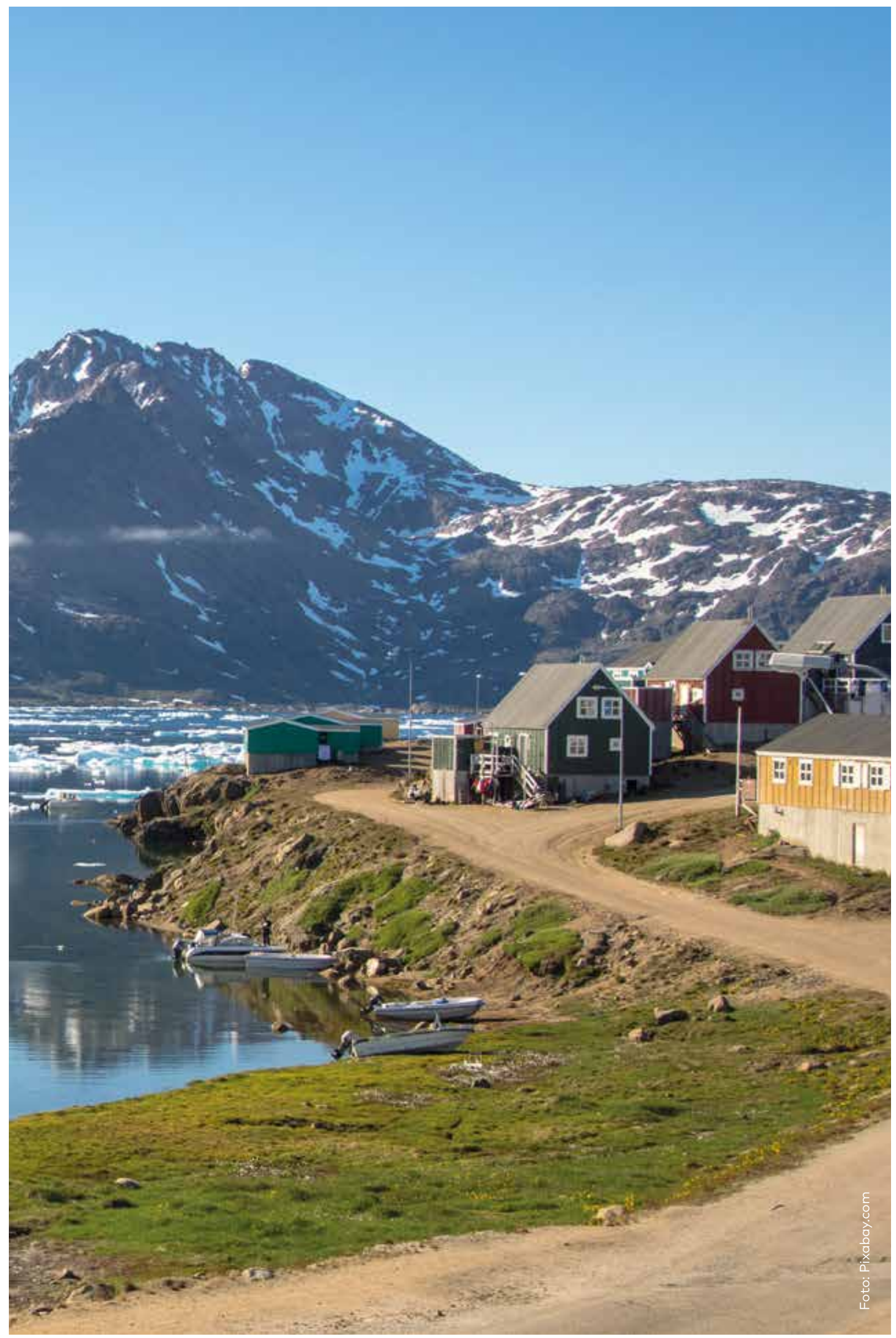




\title{
Digitala verktyg för att kommunicera med det offentliga fungerar inte över de nordiska gränserna
}

\author{
Digitala verktyg som t.ex. e-legitimation eller e-signatur som används \\ när enskilda och företag kommunicerar med det offentliga i de nordiska \\ länderna fungerar inte över de nordiska gränserna.
}

Ett prioriterat gränshinder av Eva Tarselius Hallgren, Sverige, Risto E.J. Penttilä, Finland, Siv Fridleifsdottir, Island och John Johannessen, Färöarna.

Detta är ett av de 15 gränshinder som prioriterades av arbetsmarknadens parter i Norden vid näringslivskonferensen på Børsen i Köpenhamn den 30 april 2015.

Prioriterat av Gränshinderrådet sedan 2016.

\section{Bakgrund}

I de nordiska länderna har en rad digitala verktyg för e-förvaltning utvecklats som ska underlätta mötet mellan det offentliga och enskilda och företag. Dessa verktyg kan underlätta den administrativa bördan för företagen och enskilda och spara dem värdefull tid. Dessvärre har dessa verktyg inte tagits fram för att kunna fungera över de nordiska gränserna. Ofta krävs det dessutom ett personligt möte eller att en verksamhet ska ha en särskild juridisk status för att få tillgång till en viss tjänst. I vissa fall är det över huvud taget inte möjligt för det utländska företaget att ta del av infrastrukturen för e-förvaltning på marknaden i ett annat land.

I de nordiska länderna har en lång rad e-tjänster som e-signaturer och e-identifikation (t.ex. Nem-ID) tagits fram på ett nationellt plan för att underlätta administrativa bördor, reducera omkostnader, förkorta handläggningstid och bespara medborgare och företag värdefull tid i kontakten med det offentliga.

För enskilda som på grund av arbete eller av någon annan anledning har myndighetskontakter i ett annat land än det där de är bosatta, eller som väljer att flytta till ett annat land, kan tillgången till e-förvalt- ning och tjänster som e-id i det andra landet väsentligt förenkla förutsättningarna för detta.

Inom ramen för EU:s handlingsplan för e-förvaltning 2016-2020 vidtar Europeiska kommissionen åtgärder för att förbättra tillgången till gränsöverskridande e-tjänster för kontakten med myndigheter och även gränsöverskridande elektronisk identifiering.

Det pågår även ett arbete för att genomföra en EU-förordning om gränsöverskridande e-legitimationer, den s.k. elDAS-förordningen, som syftar till att möjliggöra för medborgare och företag i EU att få tillgång till digitala tjänster i andra länder. Enligt förordningen ska EU- och EES-länderna erkänna varandras digitala id under år 2018.

De danska myndigheterna Erhvervsstyrelsen och Digitaliseringsstyrelsen, det norska Direktoratet for Forvaltning og IKT och det svenska Standardiseringsinstitutet ger ett finansiellt stöd till myndigheten Dansk Standard som ska leda utvecklingen av gemensamma europeiska standarder för digital upphandling. Arbetet sker i nära samarbete med Europeiska kommissionen som aktivt bidrar till arbetet, bl.a. för att säkra att det genomförs inom det europeiska upphandlingsdirektivets tidsfrist gällande krav 
om elektroniska anbud vid upphandlingsförfaranden. Utöver Danmark, Sverige och Norge deltar en lång rad europeiska länder i detta arbete.

\section{Vem påverkas}

Företag som har för avsikt att bedriva sin verksamhet över gränserna i Norden och enskilda som har myndighetskontakter i ett annat land än bosättningslandet.

\section{Förslag till lösning}

Ett ömsesidigt erkännande av ländernas olika begrepp för identifiering möjliggör för enskilda och företag att få direkt tillgång till de offentliga digitala tjänsterna i ett annat land. Därmed underlättas bl.a. mobiliteten för enskilda och företag i Norden. Nordiska medborgare ska kunna använda sina egna säkra inloggningslösningar, såsom personnummer och elektronisk legitimation, oavsett var de befinner sig.

Ministerrådet för digitalisering, MR-DIGITAL, beslutade den 8 december 2017 att starta ett treårigt projekt för att säkerställa en gemensam nordisk lösning för elektronisk identifiering för alla nordbor. Vid mötet konstaterade generalsekreteraren att elektronisk identifiering kan vara den enskilt viktigaste åtgärden sedan den nordiska passfriheten för att förenkla vardagen för invånarna i Norden när de flyttar till ett annat nordiskt land. Projektet leds av Norge och är en flera viktiga insatser på digitaliseringsområdet under det svenska ordförandeskapsåret.

\section{Gränshinderrådets arbete med frågan/ kommentarer från berörda regeringar}

Risto E.J. Penttilä, Finland:

Saken aktuell i inväntan på arbetet i det nya ad hoc ministerrådet
Finansdepartementet, Sverige:

Nyckeln till e-förvaltning över gränserna är erkännande av varandras e-legitimationer, snarare än själva tjänsterna i sig. Ett omfattande arbete pågår i Europa med att genomföra elDAS-förordningen där regler om att länderna ska kunna ta emot varandras (notifierade och godkända) e-legitimationer träder i kraft den 29 september 2018. I Sverige ansvarar E-legitimationsnämnden för detta, bl.a. genom att sätta upp landsnoden för eIDAS-trafik och informera offentliga myndigheter om anpassningar som behöver göras med anledning av den nya lagstiftningen.

Vikten av att genomföra eIDAS-förordningen har adresserats i tre ministerdeklarationer under 2017: Oslo-deklarationen "Digital North", Tallinn-deklarationen om e-government (EU) och EaP-deklarationen om digital ekonomi (Östra partnerskapet).

Nordiska rådet fattade under sin 69:e session beslut om att föreslå regeringarna att införa ömsesidigt erkännande av e-legitimationer i Norden och att säkerställa att de nordiska ländernas e-legitimation och e-signatursystem erkänns i Norden med kompatibla system inom alla sektorer så att den enskilda nordiska medborgaren inte upplever problem med att legitimera sig till vardags i Norden.

Inom ramen för Nordiska ministerrådet bedrivs ett projekt om nordiska eID. Sverige deltar i projektet med experter från E-legitimationsnämnden och Finansdepartementet.

Läs mer i gränshinderdatabasen, granshinder.norden.org, gränshinder nr: 17-010. 


\title{
Erkännande av föräldraskap för familjer med samkönade föräldrar
}

\author{
Flera nordiska länder erkänner inte föräldraskap som har fastställts med stöd \\ av samtycke i andra nordiska länder när föräldrarna är av samma kön och \\ barnet har tillkommit genom assisterad befruktning.
}

Ett prioriterat gränshinder av Siv Fridleifsdottir, Island.

Prioriterat av Gränshinderrådet sedan 2017.

\begin{abstract}
Bakgrund
När ett samkönat par får barn i Island, Sverige, Norge och Danmark genom assisterad befruktning kan föräldraskapet för den kvinna som inte fött barnet, det s.k. medmoderskapet, under vissa förutsättningar fastställas genom samtycke. Finland saknar lagstiftning för fastställande av medmoderskap som uppkommit i ett annat land och det är i nuläget oklart hur sådana fall hanteras praktiken.
\end{abstract}

Island, Norge och Danmark erkänner under vissa förutsättningar medmoderskap som har fastställts genom samtycke i andra nordiska länder för barn som har tillkommit genom assisterad befruktning. Det är dock inte möjligt i Sverige, och i Finland är situationen i nuläget oklar. I Sverige behandlas samkönade och olikkönade föräldrar olika när det gäller erkännande av föräldraskapet. För olikkönade par erkänns faderskap som har fastställts med stöd av samtycke i andra nordiska länder för barn som tillkommit genom assisterad befruktning. Detta gäller dock inte för samkönade par där medmodern måste adoptera barnet för att betraktas som dess förälder i Sverige, även om föräldraskapet framgår av den födelseattest som utfärdats för barnet i det andra nordiska landet. Denna situation medför en allvarlig risk för barnet som formellt sett förlorar en förälder när familjen flyttar till något av dessa länder. Den förälder som inte fött barnet förlorar också sin rätt till vårdnad över barnet. Den adoptionsprocess som krävs för att föräldraskapet ska vara giltigt i Sverige är dessutom administrativt och tidsmässigt krävande och kan upplevas som kränkande för den berörda familjen.
Finland saknar i nuläget regler för att erkänna medmoderskap som fastställts genom samtycke i andra nordiska länder. Därför är det i nuläget oklart hur erkännande av medmoderskap som fastställts i ett annat land hanteras i praktiken.

\section{Sverige:}

Den situation som beskrivs kan uppstå även för svenska samkönade par i Sverige. För dessa fall har Utredningen om utökade möjligheter till behandling av ofrivillig barnlöshet föreslagit bl.a. att samtycke ska kunna utgöra grund för föräldraskap också vid behandlingar vid behöriga sjukvårdsinrättningar i utlandet om den person som tillkommit genom behandlingen har rätt att ta del av uppgifter om donatorns identitet (SOU 2016:11). Syftet med detta villkor är att säkra barnets rätt till information om sitt genetiska ursprung. Förslaget bereds för närvarande inom Regeringskansliet och en lagrådsremiss planeras till början av 2018. Regeringen har också tillsatt en utredning som ska se över vissa ytterligare frågor rörande faderskap och föräldraskap. När det gäller hanteringen av frågorna i förhållande till övriga nordiska länder har det i vissa delar träffats överenskommelser mellan de nordiska länderna. Utvecklingen inom den internationella privaträtten följer $i$ regel den utveckling som sker inom den nationella lagstiftningen i takt med att länder når samsyn kring olika frågor. Det kan därför finnas anledning att titta närmare på frågan framöver.

Finland:

Finlands riksdag behandlar för närvarande ett medborgarinitiativ som innehåller ett förslag om en mo- 
derskapslag som bl.a. föreskriver att föräldraskapet för den icke-biologiske föräldern i ett samkönat par som får barn genom assisterad befruktning fastställs genom samtycke, dvs. på samma sätt som för par av olika kön (MI 3/2016 rd).

\section{Vem påverkas}

Familjer som består av mor, medmor och barn som flyttar till Sverige och möjligen även Finland efter att ha fått barn genom assisterad befruktning i ett annat nordiskt land.

\section{Förslag till lösning}

Att Sverige och Finland erkänner föräldraskap som har fastställts med stöd av samtycke i andra nordiska länder när föräldrarna är av samma kön och barnet har tillkommit genom assisterad befruktning.

\section{Gränshinderrådets arbete med frågan/ kommentarer från berörda regeringar}

Siv Fridleifsdottir, Island:

Islands representant i Grensehinderrådet har tatt hindringen opp med diverse bl.a. personer som har vært utsatte for hindringen, Islands delegasjon i Nordisk råd, representanter fra innenriksdepartementet Island, Register Iceland, Samtökin'78-The National Queer Organization in Iceland, den svenske ambassadör på Island, Bosse Hedberg og Valdís Ösp Árnadóttir, direktör for Hallo Norden Island.

Svensk minister fikk forespörsel i Riksdagen om möjligheten att erkänna andra nordiska länders beslut gällande föräldraskap vid assisterad befruktning för samkönade par som flyttat till Sverige. I ministersvar fra den 10. august 2017 fremkommer at; Ett första steg är arbetet med de nationella reglerna om föräldraskap.

Grensehinderrådet beslutade den 6. september 2017 att skicka ut ett brev till de berörda minister i Sverige og Finland från Gränshinderrådet, för att uppmärksamma den nordiska dimensionen av problemet og få opplysninger om de har planer om å avskaffe den i den nærmeste fremtid. Brevet ble sendt den 13.11. 2017. Gränshinderrådet kommer att fortsätta att följa hur frågan utvecklas under 2018.

Läs mer i Gränshinderdatabasen, granshinder.norden.org, gränshinder nr: 17-002. 


\title{
Norska regler för helikoptertrafik försvårar underhåll av renstängsel i Norge
}

\author{
Rennäring bedrivs på båda sidor av den svenska och den norska gränsen \\ och betesmarker avgränsas med renstängsel. I avsaknad av ett avtal \\ mellan länderna om hur underhållet av renstängslen ska bedrivas genomför \\ Sametinget enligt en överenskommelse med Fylkesmannen i Norge underhåll \\ av vissa renstängsel på den norska sidan. Norska regler för helikoptertrafik \\ hindrar dock Sametinget från att stängsel i Norge vilket leder till att under- \\ hållet av dem eftersätts.
}

Ett prioriterat gränshinder av Svein Ludvigsen, Norge och Eva Tarselius-Hallgren, Sverige.

Prioriterat av Gränshinderrådet sedan 2017.

\section{Bakgrund}

Den samiska befolkningen bedriver rennäring på båda sidor av gränsen mellan Sverige och Norge, och renskötsel har sedan urminnes tider bedrivits över denna gräns. Samernas rättigheter att bedriva rennäring på detta sätt reglerades mellan länderna första gången år 1751, och denna överenskommelse gäller än idag och har kompletterats med konventioner mellan Sverige och Norge om hur rennäringen ska bedrivas. Den senaste konventionen upphörde dock att gälla 2005 och som bilaga till denna konvention ingick ett avtal om underhåll av de renstängsel som avgränsar betesmarker på båda sidorna av gränsen. En ny konvention med en ny överenskommelse om underhåll av renstängsel som undertecknades år 2009 har inte ännu trätt i kraft då den inte har ratificerats av Sverige och Norge. I denna nya konvention ingår också ett avtal om underhåll av renstängsel.

Enligt den konvention som upphörde år 2005 hade den svenska myndigheten Sametinget ansvar för underhåll av vissa renstängsel i Norge. Sedan konventionen upphörde tog norska myndigheter över detta ansvar, men denna verksamhet kom sedermera att avvecklas. Den nya konvention som ännu inte har trätt i kraft ger Sametinget delvis samma ansvar för underhåll av stängsel på den norska sidan som den tidigare konventionen. Sedan norska myndigheter upphörde med underhållet genomför Sametinget underhåll av renstängsel i Norge enligt den nya konventionen. Sametinget har en överenskommelse om detta med Fylkesmännen i Sør-Trøndelag, Nor-Trøndelag samt Troms fylken.

I vissa fall måste helikopter användas för att nå vissa renstängsel på den norska sidan. När den tidigare konventionen gällde krävde norska myndigheter inte landningstillstånd eller överflygningstillstånd av Sametinget för svenska helikoptrar för att nå dessa stängsel. Sedan Sametinget har återupptagit underhållet efter att den gamla konventionen upphört att gälla kräver norska myndigheter att Sametinget har landningstillstånd och överflygningstillstånd för att kunna nå de stängsel i Norge som de bedriver underhåll på. Detta är i praktiken omöjligt med tanke på de osäkra värderförhållanden som råder i området. Dessa krav försvårar Sametingets underhåll av de renstängsel i Norge som är ett gemensamt intresse för den gränsöverskridande rennäringen mellan Sverige och Norge. Att stängslen inte underhålls fördyrar renskötselarbetet och medför ökade miljökonsekvenser då renar måste drivas tillbaka till rätt betesmark. 


\section{Vem påverkas}

Gränshindret gör det dyrare att bedriva rennäring mellan Sverige och Norge på grund av att underhållet av renstängsel som avgränsar betesmarker eftersätts. Det medför också ökade miljökonsekvenser i de fall renar måste drivas tillbaka till rätt betesmark.

\section{Gränshinderrådets arbete med frågan/ kommentarer från berörda regeringar}

Eva Tarselius Hallgren, Sverige:

Sverige anser att gränshindret är löst.

Svein Ludvigsen, Norge:

Norske myndigheter har lagt til rette for en smidig ordning av de problemer Sametinget tok opp. Saken er løst. 


\title{
Norska tullregler försvårar underhåll av renstångsel i Norge
}

\author{
Rennäring bedrivs på båda sidor av den svenska och den norska gränsen \\ och betesmarker avgränsas med renstängsel. I avsaknad av ett avtal \\ mellan länderna om hur underhållet av renstängslen ska bedrivas genomför \\ Sametinget enligt en överenskommelse med Fylkesmannen i Norge underhåll \\ av vissa renstängsel på den norska sidan. Norska tullregler gör det emellertid \\ svårt för Sametinget att ta in den materiel I Norge som behövs för att \\ genomföra detta arbete, vilket leder till att underhållet av vissa renstängsel i \\ Norge eftersätts.
}

Ett prioriterat gränshinder av Svein Ludvigsen, Norge och Eva Tarselius-Hallgren, Sverige.

Prioriterat av Gränshinderrådet sedan 2017.

\section{Bakgrund \\ Den samiska befolkningen bedriver rennäring på båda sidor av gränsen mellan Sverige och Norge, och renskötsel har sedan urminnes tider bedrivits över denna gräns. Samernas rättigheter att be- driva rennäring på detta sätt reglerades mellan länderna första gången år 1751, och denna över- enskommelse gäller än idag och har kompletterats med konventioner mellan Sverige och Norge om hur rennäringen ska bedrivas. Den senaste konventionen upphörde dock att gälla 2005 och som bilaga till denna konvention ingick ett avtal om underhåll av de renstängsel som avgränsar betesmarker på båda sidorna av gränsen. En ny renskötselkonvention som undertecknades år 2009 har inte ännu trätt i kraft då den inte har ratificerats av Sverige och Norge. I denna nya konvention ingår ett avtal om underhåll av renstängsel.}

Enligt den konvention som upphörde år 2005 hade den svenska myndigheten Sametinget ansvar för underhåll av vissa renstängsel i Norge. Sedan konventionen upphörde tog norska myndigheter över detta ansvar, men denna verksamhet kom sedermera att avvecklas. Den nya konvention som ännu inte har trätt i kraft ger Sametinget delvis samma ansvar för underhåll av stängsel på den norska sidan som den tidigare konventionen. Sedan norska myndigheter upphörde med underhållet genomför Sametinget underhåll av renstängsel i Norge enligt den nya konventionen. Sametinget har en överenskommelse om detta med Fylkesmännen i Sør-Trøndelag, Nor-Trøndelag samt Troms fylken.

För att genomföra underhåll av renstängsel i Norge behöver Sametinget föra material bestående av maskiner, verktyg och delar av stängsel över gränsen till Norge. Enligt norsk lagstiftning är införsel av denna sorts material för rendrift befriad från tullavgift, men den omfattas av ordinarie krav på bl.a. deklarering vid in- och utförsel. När den tidigare konventionen gällde behövde Sametinget enbart meddela norsk tullmyndighet när de skulle föra över material för stängselunderhåll på den norska sidan. Sedan Sametinget har återupptagit underhållet efter att den gamla konventionen upphört att gälla måste Sametinget emellertid uppfylla de krav som följer av norsk lagstiftning och uppsöka en tullstation för att deklarera införsel och eventuell utförsel av sådant material. Detta innebär en administrativ börda som försvårar Sametingets underhåll av de renstängsel i Norge som är ett gemensamt intresse för den gränsöverskridande rennäringen mellan Sverige och Norge. Att stängslen inte underhålls fördyrar renskötselar- 
betet och medför ökade miljökonsekvenser då renar måste drivas tillbaka till rätt betesmark.

\section{Vem påverkas}

Gränshindret gör det dyrare att bedriva rennäring mellan Sverige och Norge på grund av att underhållet av renstängsel som avgränsar betesmarker eftersätts. Det medför också ökade miljökonsekvenser i de fall renar måste drivas tillbaka till rätt betesmark.

\section{Gränshinderrådets arbete med frågan/} kommentarer från berörda regeringar

Eva Tarselius Hallgren, Sverige:

Sverige anser att gränshindret är löst.

Svein Ludvigsen, Norge:

Norske myndigheter har lagt til rette for en smidig ordning av de problemer Sametinget tok opp. Saken er løst. 


\section{Dokumentationskrav för folkbokföring i Norge}

Ett prioriterat gränshinder av Svein Ludvigsen, Norge.

Prioriterat av Gränshinderrådet sedan 2017.

\section{Bakgrund}

När en nordisk medborgare, inklusive norska medborgare, flyttar till Norge från ett annat nordiskt land, och har för avsikt uppehålla sig i Norge i mera än sex månader, har personen i fråga plikt att folkbokföra sig hos norska Skatteetaten inom 8 dagar efter ankomst till landet.

Som dokumentation för att kunna folkbokföra sig kräver den norska Skattetaten att man möter personligt på ett av 42 utvalda skattekontor för ID-kontroll. Till ID-kontrollen ska man utöver identitetshandlingar ha med sig ett köpekontrakt på en bostad, eller ett hyreskontrakt som gäller minst 6 månader. Om man ska jobba i Norge krävs det vidare att man kan uppvisa ett anställningskontrakt som är giltigt i minst 6 månader och om man ska studera krävs det att man kan uppvisa bekräftelse på att man har en studieplats.

"Eventuell annan dokumentation" som kan bevisa att man tänker uppehålla sig mera än 6 månader i Norge kan också medtas. Det finns exempel på att det råder oklarhet om vilken dokumentation som godtas som "eventuell annan dokumentation".

Denna praxis har fört till att ett antal personer hamnar i en paradoxal situation. Om en person har för avsikt att flytta till Norge i en period på över 6 månader, men inte har ett köpekontrakt/hyreskontrakt i kombination med till exempel ett anställningskontrakt, eller studieplats, som sträcker sig över 6 månader, är folkbokföring inte möjlig, på trots av att personen i fråga har för avsikt att flytta permanent till Norge, samtidigt som plikten att låta sig folkbokföra inte uppfylls. Även norska medborgare som återvänder hem efter en period utomlands kan hamna i problem på grund av denna praxis.
Ett dylikt krav om att man ska kunna bevisa att man har bostad och anställningskontrakt eller studieplats i minst sex månader för att kunna bli folkbokförd ställs inte vid folkbokföring i varken Danmark, Finland eller Sverige, och även om problemställningen inte specifikt berör uppehållstillstånd kan dokumentationskravet verka strängt i förhållande till att nordiska medborgare automatiskt har permanent uppehållstillstånd i alla de nordiska länderna, och därför som utgångspunkt inte måste ange en orsak till inresa i eller flytt till ett annat nordiskt land.

Nordiska ministerrådets sekretariat har genom olika kanaler mottagit information om konkreta tillfällen, där personer, både nordiska och norska medborgare, hamnat i kläm på grund Skatteetatens praxis.

\section{Förslag till lösning}

En möjlig lösning är att Skatteetaten ändrar dokumentationskravet, så att det motsvarar det som ställs i de andra nordiska länderna.

\section{Gränshinderrådets arbete med frågan/ kommentarer från berörda regeringar}

Svein Ludvigsen, Norge:

Finansdepartementet i Norge opplyser at det er felles regler i Danmark, Sverige, Finland og Norge hva gjelder personlig fremmøte og ID-kontroll. Derimot er det ikke samme forvaltningspraksis når det gjelder å dokumentere planlagt opphold. I Norge vil normalt dokumentasjon for lengden på et opphold knyttes til bolig. Annen dokumentasjon godtas for bl. a. pensjonister, trygdede og personer som forsørges av andre. Grensehinderrådet har fått eksempler på att dokumentasjonskravene praktiseres annerledes og følger dette opp med Finansdepartementet under 2018.

Läs mer i Gränshinderdatabasen, granshinder.norden.org, gränshinder nr: 17-022. 


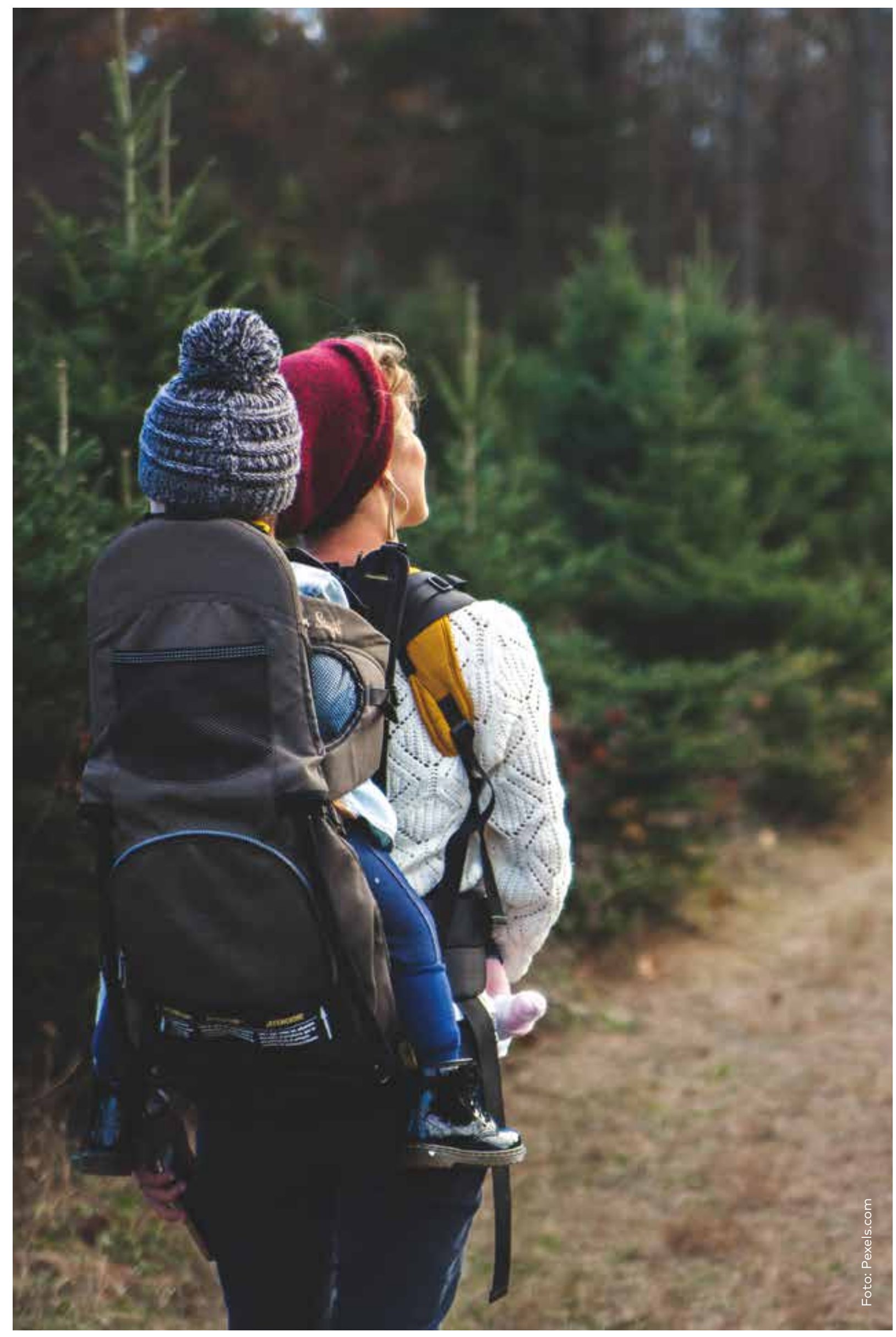




\section{Krav på utbyte av utländska körkort i Danmark}

Ett prioriterat gränshinder av Kim Andersen, Danmark.

Prioriterat av Gränshinderrådet sedan 2017.

\section{Bakgrund}

Alla nya körkort utfärdade i EU/EES efter den 19.01.2013 följer den nya harmoniserade lagstiftningen som medlemsstaterna pålades att införa på bakgrund av EU-direktiv 2006/126/EF om körkort. Följande text berör endast körkort i de klasser som nämns nedan, och som är utfärdade i ett EU/EESland, eftersom andra regler gäller för körkort utfärdade $\mathrm{i}$ ett tredjeland.

EU/EES-länder ska som utgångspunkt erkänna körkort som är utfärdade i andra medlemsländer, se direktivets art. 2 (1). Standardgiltighetstiden för körkort i klasserna $A M, A 1, A 2, A, B, B 1$ och $B E$ utfärdade efter den 19.01.2013 är som utgångspunkt 10 år, men medlemsstaterna kan välja att använda sig av en giltighetstid på upp till 15 år, se art. 7 (2)(a), vilket Danmark, Finland och Norge har gjort, men inte Sverige, som utfärdar körkort med 10 års giltighetstid. Se Kørekortbekendtgørelsen § 80, stk. 1 (DK), Körkortslag, 22 § (FI), Forskrift om førerkort m.m. § 4-1 (NO) och Körkortslag, 1 kap. 14 § (SE).

EU-direktivet gäller som utgångspunkt inte för körkort utfärdade före den 19.01.2013, se art. 13 (2). Medlemsstaterna har dock möjlighet att ställa krav om att körkort utfärdade i ett annat EU/EES-land med en längre giltighetstid än 15 år ska ombytas till ett inhemskt inom två år för att vara giltigt, se art. 2 (2). Denna regel berör i princip endast körkort utfärdade i EU/EES-länder före den 19.01.2013, eftersom körkort som utfärdats senare som huvudregel inte kan ha en längre giltighetstid än 15 år.

Danmark har utnyttjat denna möjlighet, se Kørekortbekendtgørelsen § 120, stk. 2. Avgörande i detta sammanhang är att körkortsinnehavaren är permanent bosatt i landet, vilket i praktiken innebär bosättning eller motsvarande tillknytning minst 185 dagar per år.
I nordisk kontext är det fråga om en särdansk regel, i och med att Finland, Norge och Sverige i sin körkortslagstiftning inte ställer ett dylikt krav om utbyte av EU/EES-körkort med en giltighetstid på över femton år inom två år efter permanent bosättning. Se Körkortslag 59 § (FI), Forskrift om førerkort m.m. § 9-2 (NO) och Körkortslag, 6. Kap. 1 § (SE).

\section{Gränshinderrådets arbete med frågan/ kommentarer från berörda regeringar}

Svein Ludvigsen, Norge:

Dette er en sak som viser at de nordiske landene ikke forholder seg på samme måte til EU/EØS regler. I

Norge har man valgt å ikke følge samme praksis som Danmark. Derfor gjelder andre lands førerkort frem til 2033 ved den generelle utfasingen av 100-årsførerkortene. Grensehinderrådet vil ta opp med de nordiske regjeringer det uheldige i at man ikke samordner innføringen da dette er i strid med statsministererklæringen om verdens mest integrerte region.

Transport-, Bygnings- og Boligministeriet, Danmark: Ministeriet er opmærksomt på, at bestemmelsen om kørekort kan forekomme uhensigtsmæssig i forhold til det nordiske grænsesamarbejde. Ministeriet ser derfor på spørgsmålet i forhold til kørekortbekendtgørelsen.

Läs mer i Gränshinderdatabasen, granshinder.norden.org, gränshinder nr: 17-024. 


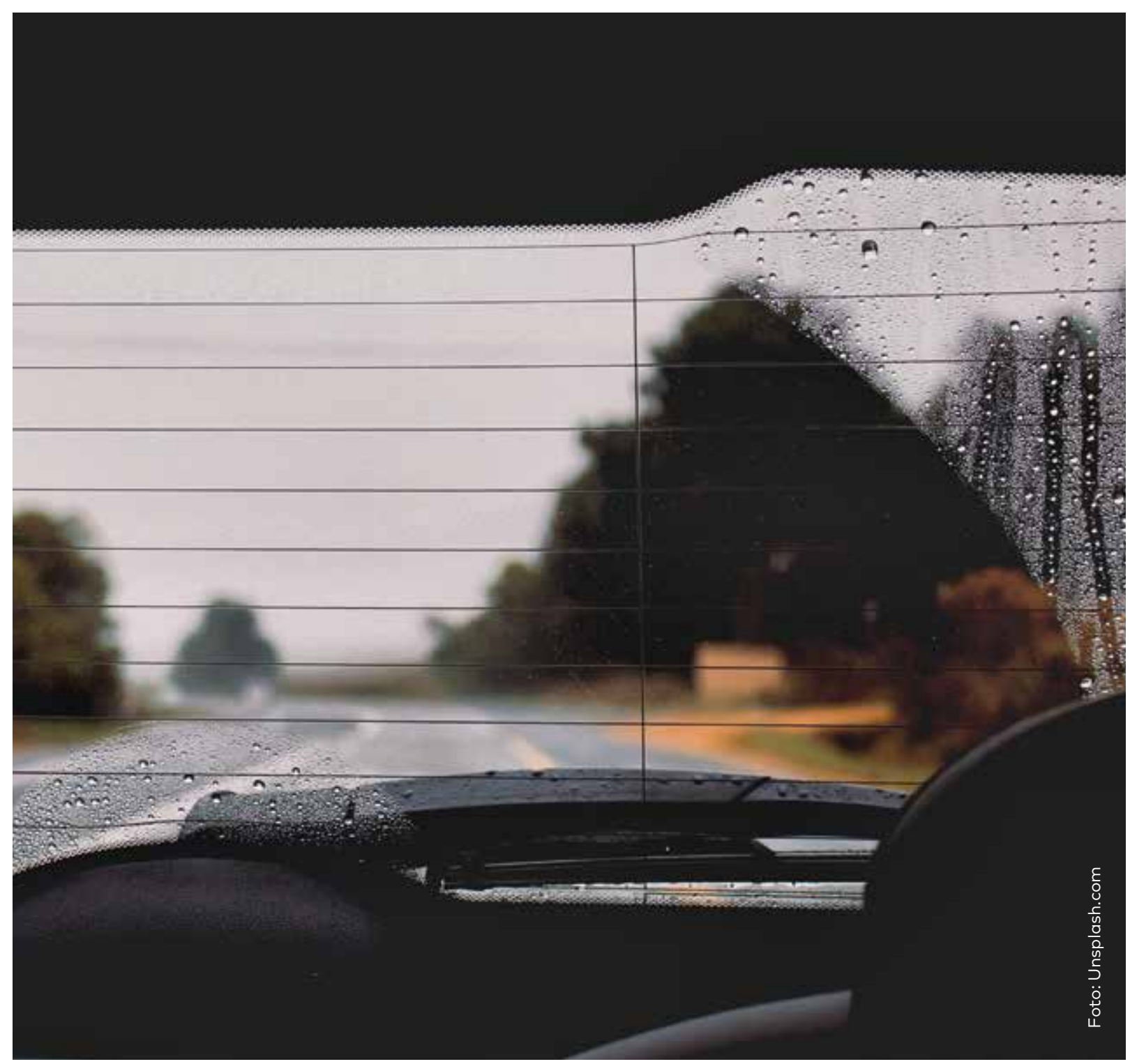




\section{Avklarade, lösta gränshinder under 2014-2017}

\section{7}

EU:s mobilitetsprogram Sverige

Begränsade möjligheter för svenska läkare att genomföra sin allmäntjänstgöring på Åland

Brist på samlad information för små och medelstora företag om att bedriva verksamhet i andra nordiska länder

Norska regler för helikoptertrafik försvårar underhåll av renstängsel i Norge

Norska tullregler försvårar underhåll av renstängsel i Norge

Ledarhund vid resa, Löst i Norge

\section{6}

Rätt till arbetslöshetsersättning efter arbeidsavklaringspenger från Norge

EU:s mobilitetsprogram Island

Vuxenutbildningsstöd till löntagare som blir studieledig

Godkännande av grönländska utbildningar

Norska tull- och momsregler för nordiska företag

Kommersiell passagerarbåttrafik över gränsen mellan Sverige och Norge

Gränsregional statistik

Behörighet för svenska snöskoteråkare att köra i Norge 


\section{5}

Arbetsrehabilitering i bosättningslandet

Handläggningstiden inom socialförsäkringsområdet i Norge

Ingen rätt till studiestöd efter arbete utomlands

Studerandes socialförsäkring i ett annat nordiskt land

Dubbelbeskattning Grönland och Sverige/Finland

Beskattning av dansk kapitalpension

Rutiner för skattehantering för äkta gränsgångare (Norge)

Beskattning av utländska pensioner i bosättningslandet

Erläggande av mervärdeskatt vid överförande av arbetsmaskin från Norge till Sverige

Finskt krav på säkerhet vid tillfällig import av husvagnar, skotrar, etc

Arjeplogavtalet

\section{4}

Språkkrav för danska yrkesutbildningar

Problem vid flytt till Island med kvalifikationsperiod på 6 månader om E-104 blankett saknas 


\section{Avklarade, inte lösta 2014-2017 Avskrivna av berörda departement}

\section{7}

\section{Rätt till inkomstrelaterad arbetslöshetsersättning i Sverige efter arbeidsavklaringspenger från Norge}

Den som ansöker om arbetslöshetsersättning i Sverige efter att ha uppburit arbeidsavklaringspenger (AAP) i Norge kan gå miste om inkomstrelaterad arbetslöshetsersättning. Eftersom perioder med AAP inte betraktas som försäkringsperioder som ger rätt till arbetslöshetsersättning i Norge, kan de inte läggas till grund för inkomstrelaterad arbetslöshetsersättning i Sverige.

Läs mer i gränshinderdatabasen, granshinder.norden.org, gränshinder nr: 17-012.

\section{Flytt med handikappfordon i Norge}

Personer med handikappfordon (t.ex. bil) kan inte ta med sig sitt handikappfordon över gränsen vid flytt, utan måste ansöka om ett nytt fordon i det nya bosättningslandet. På grund av lång handläggningstid kan detta innebära att flytt blir omöjligt för personer som har ett starkt och dagligt behov av ett transportmedel av detta slag.

Läs mer i gränshinderdatabasen, granshinder.norden.org, gränshinder nr: 14-102.

\section{6}

\section{Begränsade möjligheter för gränsarbetare att arbetspendla till Norge}

Enligt norska regler har gränsarbetare som arbetar i Norge och bor i ett annat nordiskt land begränsade möjligheter att arbetspendla till Norge med utlandsregistrerad bil om de inte är gifta eller har minderåriga barn $\mathrm{i}$ bosättningslandet.

\section{Problem med fast anställda kulturarbetare i Sverige}

Beskattning av kulturarbetare i det nordiska skatteavtalet regleras i bestämmelsen för "artister och sportutövare". Inkomster som faller in under den artikeln får i gränsöverskridande fall beskattas i både Danmark och Sverige. Förekommande dubbelbeskattning undanröjs genom avräkning i hemviststaten. I fråga om andra grupper av arbetstagare undanröjs däremot dubbelbeskattning i stor utsträckning genom att inkomsterna helt undantas i hemviststaten med följd att beskattning bara sker i ett land, arbetslandet.

Läs mer i gränshinderdatabasen, granshinder.norden.org, gränshinder nr: 14-066. 


\section{Rutiner för skatteinbetalning för äkta gränsgångare}

Personer och arbetsgivare som bor och verkar i de gränskommuner i Sverige och Finland som gränsar mot Norge upplever problem med skatteinbetalningar.

Läs mer i gränshinderdatabasen, granshinder.norden.org, gränshinder nr: 14-056.

\section{Eltariffer för Åland}

Åland importerar större delen av sin elektricitet från Sverige via kabel som ägs av Kraftnät Åland AB. Kabeln är ansluten till det svenska regionalnätet som i detta fall ägs av Vattenfall regionnät $A B$, vilket innebär att Åland måste betala regionnätsavgifter till Vattenfall.

Läs mer i gränshinderdatabasen, granshinder.norden.org, gränshinder nr: 14-162.

\section{Gränshinder som härstammar ur det nordiska skatteavtalet}

Vid sitt möte den 19 april 2016 gav de nordiska samarbetsministrarna Gränshinderrådet uppdraget att ta fram en översikt över de gränshinder som härstammar från det nordiska skatteavtalet. I den sammanställning som Gränshinderrådet lämnade till de nordiska samarbetsministrarna ingår fyra hinder som begränsar mobiliteten för individer i Norden. Dessa hinder är:

- $\quad$ Problem med fast anställda kulturarbetare i Sverige (Gränshinderdatabasen nr. 14-066)

- Rutiner för skatteinbetalning för äkta gränsgångare (Gränshinderdatabasen nr. 14-056)

- Beskattning av utbetalningar från utländska pensioner i bosättningslandet samt utbetalningar enligt ett lands sociallagstiftning (Gränshinderdatabasen nr. 15-005)

- Beskattning av studiestöd (Gränshinderdatabasen nr. 14-156)

De nordiska samarbetsministrarna beslutade att lämna denna sammanställning till Ministerrådet för ekonomi och finanspolitik som har beslutat att väga in dessa gränshinder i arbetet om de nordiska länderna beslutar att se över det nordiska skatteavtalet. Av denna anledning har Gränshinderrådet beslutat att avskriva hindren om fast anställda kulturarbetare och rutiner för skatteinbetalning för äkta gränsgångare. Hindren om beskattning av utländska pensioner och beskattning av studiestöd är sedan tidigare avskrivna av Gränshinderrådet då det saknandes förutsättningar för att lösa dem. 


\section{5}

\section{Den norska faderskvoten}

Män som arbetar i Norge, men som har en hustru/partner som inte bor eller arbetar i Norge, har ingen självständig rätt till faderskvoten (fedrekvoten) vid föräldraledighet med barn.

\section{Svar fra Norge}

Norske barne- likestillings- og inkluderingsdepartementet anser at saken ikke kan løses av politiske årsaker. Grensehinderrådet avslutter derfor arbeidet med problemet.

Läs mer i gränshinderdatabasen, granshinder.norden.org, gränshinder nr: 14-126.

\section{4}

\section{Arbetspraktik i ett annat nordiskt land}

En person som är arbetslös kan inte genomföra praktik i ett annat nordiskt land, eftersom de nationella regelverken primärt baseras på att praktik genomförs i bosättningslandet.

\section{Svar från MR-A}

Danska Rambøll har på uppdrag av ÄK-A undersökt gränshindret. Baserat på rapportens slutsatser har ÄK-A inställt till MR-A att gränshindret ska tas bort från A-sektorns prioriteringslista. Gränshindret var på dagordningen på MR-A möte i Köpenhamn den 20 november 2014 och länderna beslutade gemensamt att inte arbeta vidare med frågan om arbetspraktik.

Läs mer i gränshinderdatabasen, granshinder.norden.org, gränshinder nr: 14-002. 


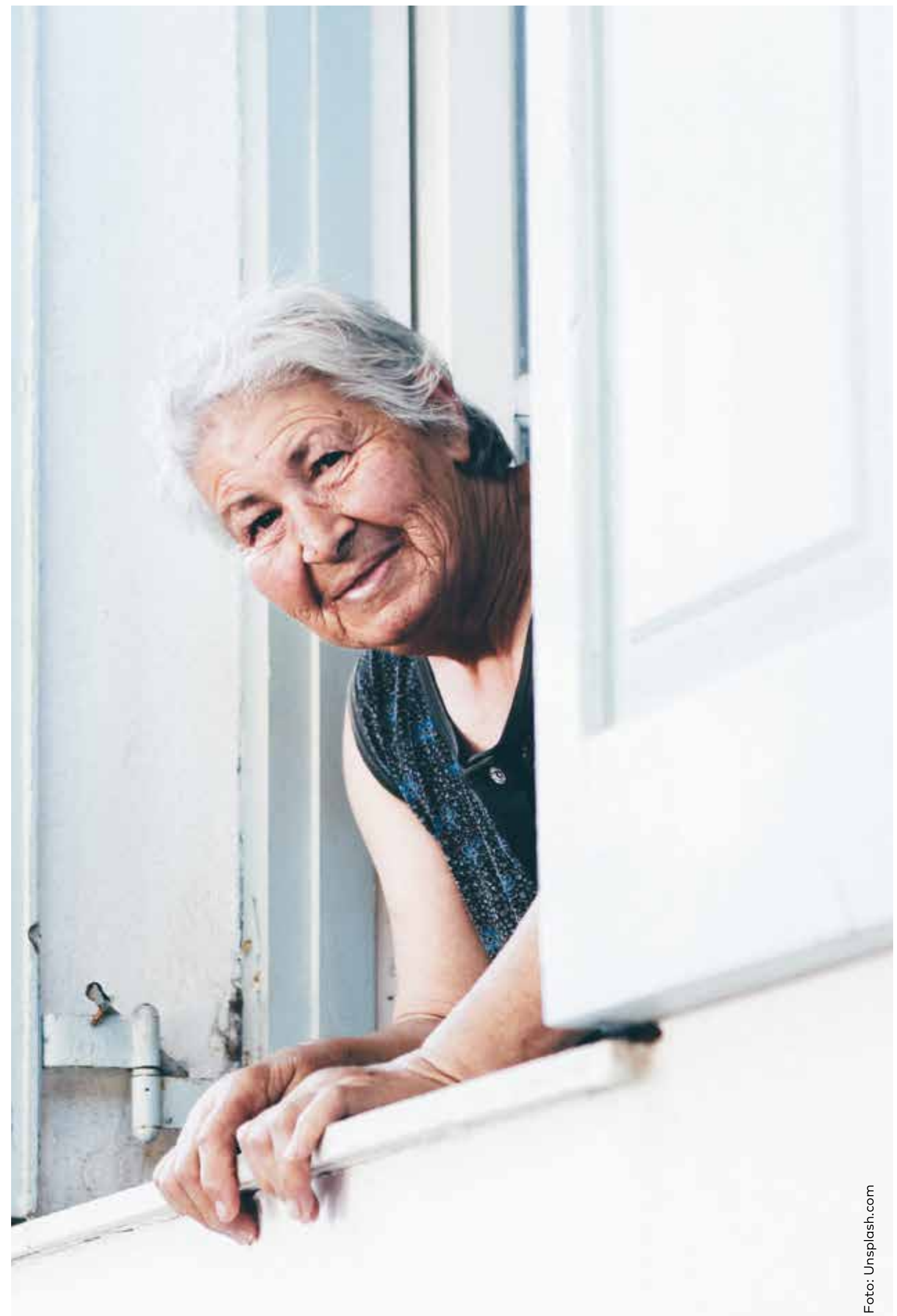




\section{Nordiska rådets Gränshindergrupp}

Nordiska rådets Gränshindergrupp har under 2017 arbetat vidare med de gränshinder som utskotten under våren och sommaren valt att prioritera: Samordningsnummer för utländska fritidshusägare i Sverige, erkännande av Färöiska körkort i Sverige, märkning av läkemedel, ett nordiskt pantsystem för flaskor, problem kopplade till geoblocking, revideringen av det nordiska dubbelbeskattningsavtalet, erkännande av yrkeskvalifikationer, arbetspraktik över gränserna med mera.

Gruppen har haft ett längre arbetsmöte (oktober), men annars endast haft kortare möten i samband med ordinarie utskottsmöten i januari och april.

I oktober träffade gruppen Danmarks nordiska samarbetsminister, för att diskutera dels hur man i Danmark arbetar för att motverka och undanröja gränshinder, men även för att diskutera samordning mellan ordförandeskapet, Gränshinderrådet och Gränshindergruppen/Nordiska rådet. Ministern stödde också Gränshindergruppens ambition att i samband med sina möten träffa värdlandets nordiska samarbetsminister eller annan minister.

Gränshindergruppen sände i mars ett brev till talmannen i Finlands Riksdag, med en uppmaning till henne om att ta initiativ till en nordisk arbetsgrupp för att se på best practice i förhållande till motverkandet av nya gränshinder i samband med nationell lagstiftning. Denna fråga diskuterades sedan på talmännens möte i Helsingfors i november. Det arbetas nu vidare med frågan, i dialog mellan Nordiska rådet och talmännen.

Nordiska rådet, genom Utskottet för tillväxt och Utveckling i Norden samt Presidiet, sände i oktober ett brev till de nordiska samarbetsministrarna, rörande det reviderade mandatet till Gränshinderrådet. I brevet pekade Nordiska rådet på ett antal problemställningar som man önskade att ministrarna skulle förhålla sig till, däribland Gränshinderrådets medlemmars frihet att agera samt samordningen mellan Gränshinderrådet och det aktuella ordförandeskapet gällande prioritering av gränshinder och ansvar för ouppnådda resultat. Man framförde även önskemål om att Gränshinderrådets medlemmar skulle tillhandahållas relevanta nätverk för att på så sätt effektivare kunna förstå och bidra till att lösa konkreta hinder.

Gränshindergruppen har bett Nordiska rådets presidium att anordna en frågetimme om gränshinder i samband med rådets sessioner. Detta för att upprätthålla ett visst tryck på de nordiska regeringarna. I samma syfte kommer Gränshindergruppen även att framöver bjuda in ansvariga ministrar till varje möte i gruppen.

Som ett led i samma strävan har Gränshindergruppen beslutat att skriva ett brev till de nordiska regeringarna, för att få svar på vad de har tänkt sig att göra med de konkreta gränshinder som är oavklarade sedan 2014 och 2015. Vill man lösa dem eller inte, och om ja, varför dröjer det?

Gränshindergruppen har även bett Nordiska rådets presidium att framföra till det svenska ordförandeskapet att man önskar att det genomförs en så kallad "strategisk genomlysning" av det nationella arbetet för att undanröja gränshinder, med förslag om hur detta kan förbättras och effektiviseras.

Gränshindergruppen beslutade i oktober att undersöka möjligheten att ingå ett nordiskt avtal som ska göra det möjligt för kommuner, regioner och gränsnära myndigheter att ingå avtal över gränserna, som avviker från de ordinarie nationella regelverken. Det arbetas nu med utkast till en sådan avtalstext.

Under 2017 hölls det gränshinderdebatter i flertalet nordiska parlament. Den danska delegationen valde istället att anordna "hearings" med flera ansvariga ministrar, där dessa ombads redogöra för sina insatser för att lösa konkreta gränshinder. Gränshindergruppen har uppmanat övriga delegationer i Nordiska rådet att följa den danska delegationens exempel.

Sist men inte minst så har Gränshindergruppen önskat en översyn av sammansättningen i gruppen, med förhoppningen om att gruppen från och med 2018 även avspeglar nationaliteterna och partigrupperna $\mathrm{i}$ Nordiska rådet. Idag är endast utskotten och presidiet representerade i gruppen. 


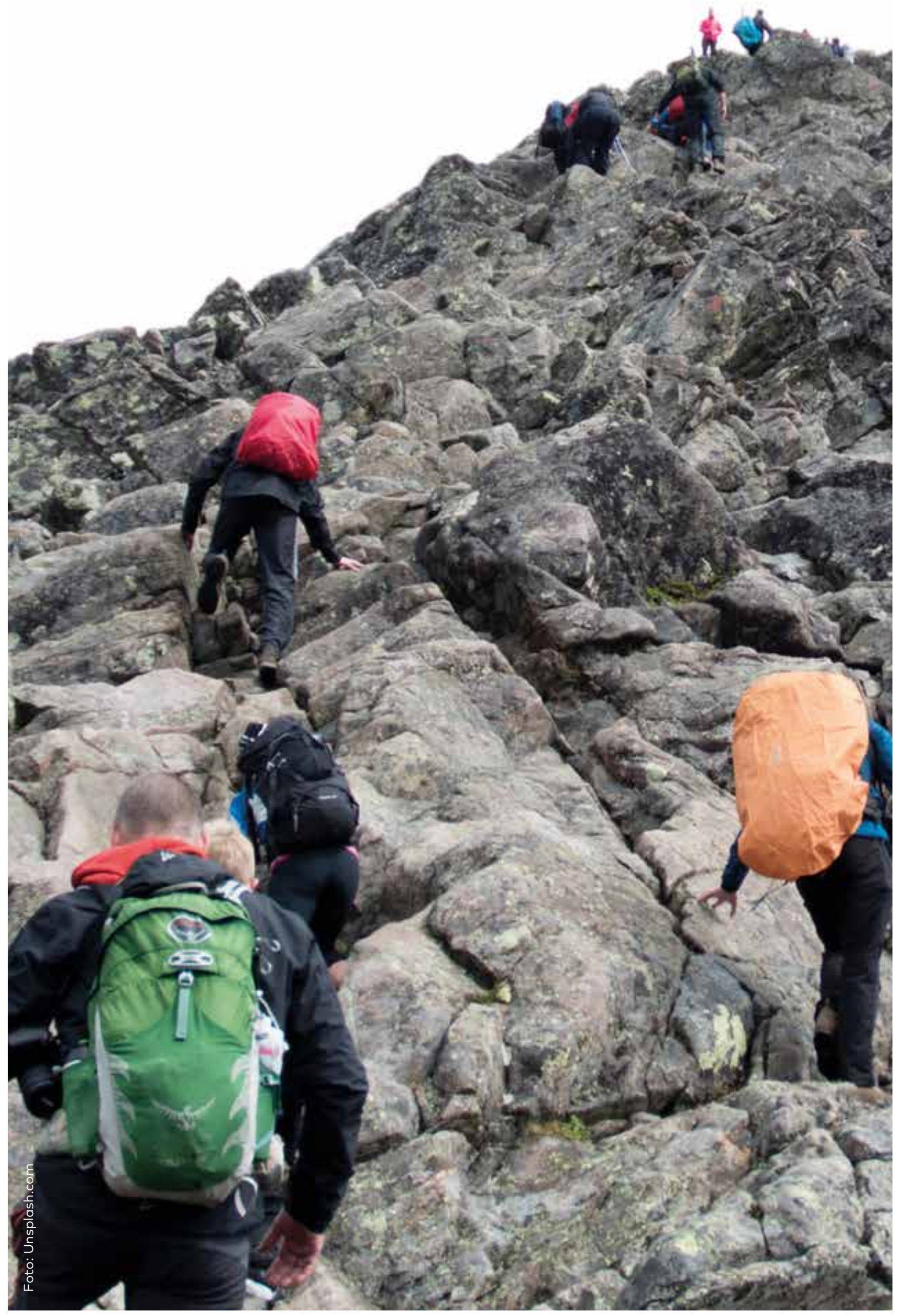




\section{Dialogen med arbetsmarknadens parter}

\section{Näringslivskonferensen med fokus på gräns- hinder som hämmar mobilitet och tillväxt i Norden 2015}

Under det danska ordförandeskapet i Nordiska ministerrådet 2015 hölls en näringslivskonferens på Børsen i Köpenhamn med fokus på gränshinder som begränsar tillväxten i Norden.

Inför konferensen bildades en arbetsgrupp med uppdraget att identifiera, prioritera och sammanställa en lista över gränshinder som hämmar tillväxten i Norden och att ta fram lösningsförslag.

Gruppens medlemmar utgjordes av representanter från arbetsmarknadens parter i Danmark och gruppen koordinerade sitt arbete med sina nordiska systerorganisationer.

Dessutom ingick Gränshinderrådets sekretariat och Gränshinderrådets danske medlem Ole Stavad i arbetet.

I samband med att den lista med femton gränshinder som arbetsgruppen tog fram presenterades vid näringslivskonferensen, meddelade den danska samarbetsministern att den dessutom skulle sändas vidare till den danska statsministern eftersom förslagen var tydliga, genomtänkta och väl förankrade i Norden.

På det nordiska statsministermötet den 3 oktober 2015 beslutades att Nordiska ministerrådets generalsekreterare Dagfinn Høybråten skulle se över möjligheten för en stärkt dialog mellan arbetsmarknadens parter $\mathrm{i}$ Norden, Gränshinderrådet samt relevanta ministrar.

De nordiska statsministrarna möttes igen i Reykjavik den 28 oktober där de gav generalsekreteraren uppdraget att förbereda en dialog om gränshinder som begränsar mobilitet och tillväxt i Norden. Statsministrarna antog även en deklaration om vikten av en effektiv dialog mellan arbetsmarknadens parter $\mathrm{i}$ Norden, Gränshinderrådet och berörda ministerier.

\section{Dialogmöten i syfte att kartlägga gränshinder i Norden 2016}

Under perioden april-juni 2016 inledde respektive nationell Gränshinderrådsmedlem tillsammans med sin nordiska samarbetsminister dialogen med arbetsmarknadens parter i sina länder brevledes och i flertalet fall genom uppföljande möten med arbetsmarknadens parter och näringslivsorganisationer.

I denna dialog- och kartläggningsfas ombads arbetsmarknadens parter och näringslivsorganisationerna att rapportera in vilka gränshinder de ansåg främst begränsade mobilitet och tillväxt i Norden.

Av de 28 gränshinder som inkommit under denna dialog har problem med erkännande av yrkeskvalifikationer mellan de nordiska länderna och behovet av information till små och medelstora företag som vill bedriva sin verksamhet över de nordiska gränserna prioriterats av organisationer i hela Norden. Dessa hinder diskuterades under 2017.

\section{Åtta nationella dialogmöten i Norden 2017}

Under 2017 har åtta nationella lösningsorienterade dialogmöten med arbetsmarknadens parter i Norden avhållits.

Vid dessa möten har Gränshinderrådets nationella medlem, samt vid de flesta möten, samarbetsministern tillsammans med arbetsmarkandens parter diskuterat de två gränshinder som parterna ansett vara viktigast att få löst, branschreglerade yrkeskvalifikationer och information till små och medelstora företag.

Syftet med de nationella lösningsorienterade dialogerna har varit att diskutera och tillsammans finna lösningar på de två prioriterade gränshindren.

Resultaten från dialogmötena har varit goda. När det gäller information till små och medelstora företag har Nordiska ministerrådet utvecklat en länkportal (nordenbusiness.org) för näringslivet i Norden. Portallösningen mottogs positivt av parterna i Norden och de kommer att bidra till att synliggöra portalen via sina nationella kanaler. Parterna ställde sig positiva till att få en genomlysning av gränshindret som berör branschrelaterade yrkeskvalifikationer genom att fokusera på ett pilotprojekt inom en bransch. 


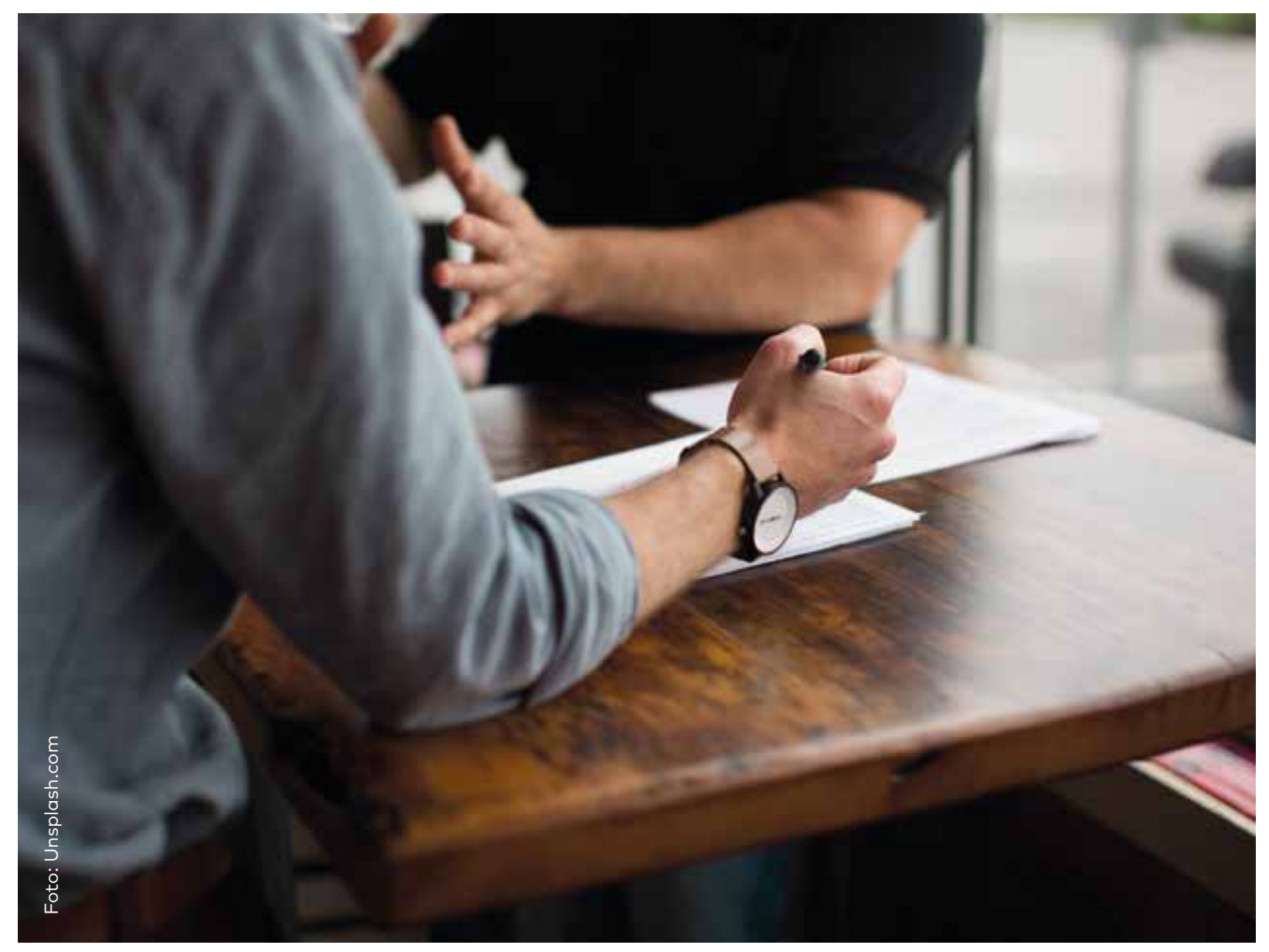

Då näringslivsfrågor särskilt är markerade i Gränshinderrådets nya mandat kommer dialogen med parterna fortsättningsvis att ske genom Gränshinderrådets nationella nätverk. 


\section{Informationsarbetet}

Nordiska ministerrådets informationstjänst Hallå Norden och de tre gränsregionala informationstjänsterna Nordkalottens Gränstjänst, Grensetjänsten och Öresunddirekt har särskild betydelse för det nordiska gränshinderarbetet och finansieras i olika omfattning av Nordiska ministerrådet.

Informationstjänsterna skapar trygghet för privatpersoner och företag som vill röra sig mellan de nordiska länderna och behöver hjälp med att finna information om regler och myndighetskontakter.

Dessa tjänster utgör Gränshinderrådets strategiska frontlinje. De registrerar alla förekommande gränshinder samt analyserar om dessa kan lösas lokalt, regionalt eller nationellt. De identifierade gränshindren inrapporteras därefter till Gränshinderrådets sekretariat och dokumenteras i den nordiska gränshinderdatabasen.

Tillsammans har samtliga informationstjänster under 2017 genererat över 1950000 webbesök samt drygt 36000 personliga kontakter (besök, e-post, telefon och gruppbesök).

Gränshinderarbetet har effektiviserats genom att Gränshinderrådets sekretariat tillsammans med informationstjänsterna har utvecklat en gemensam samarbetsplattform, LOTS-gruppen (den Nordiska Lösningsfokuserade Orienterande Tjänstgörande Samordnare-gruppen). Denna grupp träffas fyra gånger om året.

Gruppen har utvecklat en gemensam handlingsplan för hur man ska effektivisera gränshinderarbetet och informationsinsatserna.

Utöver informationstjänsterna ingår elva av tolv gränskommittéer i LOTS-gruppen. Dessa arbetar med gränshinderfrågor och spelar också en betydelsefull roll i gränshinderarbetet.

Bland de operativa samarbeten som har genomförts inom ramen för handlingsplanen under 2016 kan nämnas en konferens om gränshinder på arbetsmarknadsområdet med fokus på arbetslöshetsersättning i Sverige den 12-13 oktober 2016 och två
Interregprojekt som har till syfte att öka rörligheten för små och medelstora företag i Norden. Projektet Näringslivsvägledningen på Nordkalotten implementeras i den gränsregion på Nordkalotten som omfattar Sverige, Norge och Finland. Projektet Gränsmöjligheter genomförs längs hela den norsk-svenska gränsen.

Gränshinderrådets sekretariat ingår dessutom i de gränsregionala informationstjänsternas styrgrupper samt deltar ibland i Hallå Nordens arbetsgrupp.

I de fall där Gränshinderrådets medlemmar håller förmöten inför Gränshinderrådets ordinarie möten deltar informationstjänsterna och de gränsregionala kommittéerna i dessa.

Inför kommande år är ambitionen att närmare samordna Hallå Norden och de gränsregionala kommittéerna för att öka effektiviteten och mervärdet av de samlade informationsaktiviteterna. 


\begin{tabular}{|c|c|c|c|c|c|}
\hline & Webb & $\begin{array}{r}\text { Följare } \\
\text { Facebook }\end{array}$ & $\begin{array}{l}\text { Följare } \\
\text { Twitter }\end{array}$ & $\begin{array}{l}\text { Personlig } \\
\text { betjäning }\end{array}$ & $\begin{array}{l}\text { Seminarier och } \\
\text { informationsträffar }\end{array}$ \\
\hline Hallå Norden & 1000298 & 8907 & 1023 & 2560 & 2000 \\
\hline $\begin{array}{l}\text { Nordkalottens } \\
\text { gränstjänst }\end{array}$ & 25830 & 540 & & 3391 & 1209 \\
\hline Grensetjänsten & 141796 & 558 & 92 & 15474 & 1405 \\
\hline$\varnothing$ resunddirekt & 788113 & 1576 & 642 & 14844 & 6306 \\
\hline Totalt & 1956037 & 11581 & 1757 & 36269 & 10920 \\
\hline
\end{tabular}

\section{Hallå Norden}

\section{Geografisk placering}

Nordisk Ministerråds informationstjeneste, Hallo Norden, har kontorer i alle de nordiske lande samt Færøerne, Grønland og Åland. Hallo Norden koordinerer sine aktiviteter i samarbejde med Nordisk Ministerråds kommunikationsafdeling.

I hvert land er der ansat en projektleder på fuld tid, mens projektlederne på Færøerne, Grønland og Åland arbejder deltid. Hallo Norden i Danmark, Finland og Grønland har i forskelligt omfang ansat projektmedarbejdere.

\section{Kort om organisationen}

Hallo Nordens opgave er at forenkle privatpersoners muligheder for at bevæge sig frit i Norden ved at publicere information om at flytte, arbejde og studere i Norden på norden.org og at besvare henvendelser fra borgere.

Hallo Norden identificerer problemer og grænsehindringer som privatpersoner møder når de krydser de nordiske grænser.

\section{Aktiviteter koblet til virksomheden}

Hallo Norden arbejder med at forbedre projektledernes sproglige kompetencer; og fokuserer på klarsprog i alle sine artikler, så borgerne får information på et klart og tydeligt sprog.

I forbindelse med Nordisk Råds session 2017 præsenterede Hallo Norden i samarbejde med Grænsehindringsrådets sekretariat fire små film om mobilitet og grænsehindringer i Norden.

Samarbejdet med Rådet for nordisk samarbejde om funktionsnedsættelse fortsatte i 2017 for at gøre det enklere for folk med funktionsnedsættelse at være mobil i Norden.

Hallo Norden samarbejder med relevante myndigheder og institutioner på lokalt, nationalt og nordisk plan for at styrke mobiliteten i Norden.

I 2017 gennemførte Hallo Norden en række arrangementer på Almedalsveckan, Arendalsuka og SuomiAreena. Hallo Norden har også afholdt informationstræf for ambassadepersonale i Norge og Sverige samt mødtes med Solvit og studenterorganisationer 
i Danmark, Norge og Sverige. I Island og på Åland har Hallo Norden gennemført informationsdage for uddannelsesinstitutioner og i Finland har Hallo Norden haft et arrangement om at søge job i Norden.

Derudover har Hallo Nordens medarbejdere informeret om mobilitet og grænsehindringer som indbudte gæster og samarbejdspartnere ved debatter, seminarer, konferencer og messer over hele Norden.

\section{Forandring siden sidste år}

Ny opgave

Hallo Norden indledte i 2017 arbejdet med at fusionere Hallo Norden og socialforsikringsportalen, NordSoc. Fusionen gennemføres i 2018. Herefter vil norden.orgs artikler om social sikring formuleres af en redaktion bestående af repræsentanter for Hallo Norden og de nordiske landes respektive socialsikringsmyndigheder.

Nyt forvaltningsorgan

I 2017 overtog Nordregio forvaltningen af Hallo Norden i Sverige.

\section{Nordkalottens gräns- tjänst, Haparanda Torneå och Skibotn}

\section{Geografisk placering}

I Torneå finns Nordkalottens Gränstjänstkontor som har fokus på frågor mellan Finland och Sverige. I Storfjord, Norge, finns kontoret som arbetar med Norge-Finland frågor, samt även Sverige-Norge frågor.

\section{Kort om organisationen}

Nordkalottrådet (NKR) är huvudman för kontoret i Torneå. Storfjord kommun äger Gränstjänsten i Skibotn och NKR bidrar till dess finansiering. Torneå har en heltidsanställd koordinator. Skibotn har en deltidsanställd koordinator (av Storfjord kommune) och en heltidsanställd rådgivare som finansieras från NAV - centralt.

\section{Aktiviteter kopplade till uppdraget}

Kontoren informerar om arbete och annan verksamhet över nationsgränserna för privata personer och företag, registrerar upplevda gränshinder och bidrar till avskaffandet av dem.

Nordkalottens Gränstjänst har nära samarbete med Gränshinderrådet och deltar i nätverket av nordiska informationstjänster.

Gränstjänst har arrangerat:

Informationsträffar 28 st / 812 deltagare

Seminarier 5 st / 210 deltagare

Personalen har deltagit i

- 41 informationsmöten

- varit medarrangör till 22 evenemang (inkl. Deklarasjons-/skattemeldingsdager)

- LOTS-möten 3 st

- Förmöten till Gränshinderrådet i Finland och Sverige

- Förenklingsgruppen 3 st.

\section{Förändring sedan föregående år}

NK Gränstjänst samarbetar med Interreg-projektet "Gränsöverskridande vägledning för näringslivet". Gränstjänsten har förmedlat bl.a. kontakter till näringslivsaktörer och till informationstjänster i Norden. Målet är en koordination av insatser och evenemang för att olika intressegrupper ska få god service.

\section{Grensetjånsten Norge-Sverige}

\section{Geografisk placering}

Morokulien Infocenter är placerat på gränsen mellan Norge och Sverige.

\section{Kort om organisationen}

Grensetjänsten Norge-Sverige har till huvuduppgift att ta emot och behandla frågor från enskilda och företag som har någon form av gränsöverskridande verksamhet. Idag är Grensetjänsten Norge-Sverige ett informationscenter med ett stort sakkunnigt kontaktnät i olika myndigheter och organisationer. 
Grensetjänsten Norge-Sverige har totalt åtta medarbetare varav NAV och Arbetsförmedlingen tillsammans har fyra fasta heltidstjänster. De övriga fyra tjänster är beroende av projektfinansiering.

\section{Aktiviteter kopplade till uppdraget}

- Workshops för företag: 3 st

- Informationsträffar till kollegor, företag, enskilda: 38 st

- Grenseråd: 2 st (ca 100 deltagare)

- Gränshinderarbete/förenklingsgruppen: 8 st

- Deklarations/selvangivelsedagar: 4 st (ca 300 deltagare)

\section{Förändring sedan det senaste året}

Kontakterna till Grensetjänsten Norge-Sverige har förändrats och det märks en klar ökning av frågor från företag. Idag rör var tredje kontakt frågor kring företagsetablering etc. och en ny tendens är att norska företag har ett ökat intresse för, eller uppdrag på, den svenska marknaden. Generellt är nivån på de frågor som ställs till Grensetjänsten Norge-Sverige mer kvalificerade idag eftersom hemsidan fångar upp de enklare frågorna.

I maj 2016 beslutades om att inom ramen för Sverige/Norge-programmet (Interreg.) bevilja finansiering till projektet Gränsmöjligheter som vänder sig till företagare längs den svensk-norska gränsen. Projektperioden löper from. Den 1 september 2016 tom. den 31 augusti 2019.

\section{Øresunddirekt}

\section{Geografisk placering}

Øresunddirekt är en offentlig informationstjänst för privatpersoner och näringsliv i gränsregionen mellan Danmark och Sverige.

\section{Kort om organisationen}

$\varnothing$ resunddirekt består av ett informationscenter i Malmö och en kommunikationsavdelning i Köpenhamn med ansvar för webbplatserna. Øresunddirekt i Danmark har tre medarbetare. Øresunddirekt i Sverige har två heltidsanställda, från Arbetsförmedlingen och Länsstyrelsen Skåne/Region Skåne, samt roterande personal från Arbetsförmedlingen, Försäkringskassan och Skatteverket. Øresunddirekt Danmark och Øresunddirekt Sverige delar varumärke men är organisatoriskt åtskilda med delvis olika finansiärer.

\section{Aktiviteter kopplade till uppdraget}

Øresunddirekt har under året:

- Ingått i "Arbejdsgruppen for grænsehindringer og arbejdsmarkedsintegration" inom ramen för Greater Copenhagen-samarbetet

- Anordnat en workshop med fokus på gränshinder för tredjelandsmedborgare

- Samarbetat med Helsingborg och Helsingör för att på olika sätt öka Øresunddirekts närvaro i den norra geografin av Öresundsregionen

- Samarbetat med Lund International Citizen Hub och International House i Köpenhamn rörande EU-medborgare, tredjelandsmedborgare och medföljande

- Startat projektet "Øresunddirekt pop-up" där målgrupperna är myndigheter, kommuner och andra relevanta organisationer som i sin tur träffar medborgare och företag i Öresundsregionen

- Deltagit på förmöten hos Utrikesdepartementet i Sverige inför Gränshinderrådets möten, Nordiska ministerrådets LOTS-möten och Grensetjänstens Grenseråd

- Haft gruppinformation om att jobba i Danmark och att läsa lärlingsutbildningar i Danmark

- Haft deklarationsinformation i samarbete med danska SKAT på informationskontoret och på webben

- Deltagit i karriär- och rekryteringsmässor i Danmark och Sverige

- Haft företagsrådgivning i samarbete med Nyföretagarcentrum Öresund och Københavns Erhvervsservice

- Haft skräddarsydda företagsmöten för verksamheter som etablerat eller flyttat kontor och personal från Sverige till Danmark

- Öresundsexperterna på webben ger onlinerådgivning till företag

- Haft studiebesök från Sveriges ambassad i Danmark, myndigheter, olika svenska kommuner och regioner $\mathrm{m}$.fl. 
- Deltagit i forskningsprojektet "Smart Transformations in City-regional Law and Governance" tillsammans med andra europeiska regioner

- Deltagit på konferensen konferens Boosting Growth and Cohesion in EU border regions i Bryssel och andra relevanta konferenser

- Anordnat en studieresa i Öresundsregionen för Sveriges Norden-ambassadör

\section{Förändring sedan senaste året}

Øresunddirekt Danmark har fått projekt för motsvarande 100000 DKK godkända inom ramen för Greater Copenhagen-samarbetet. Projektet innebär bland annat marknadsföring av tjänsten" Öresundsexperterna" som ger on-line rådgivning till företag på webben. 
$+6$

tistion.

tho $\sin ^{2}$ is

8

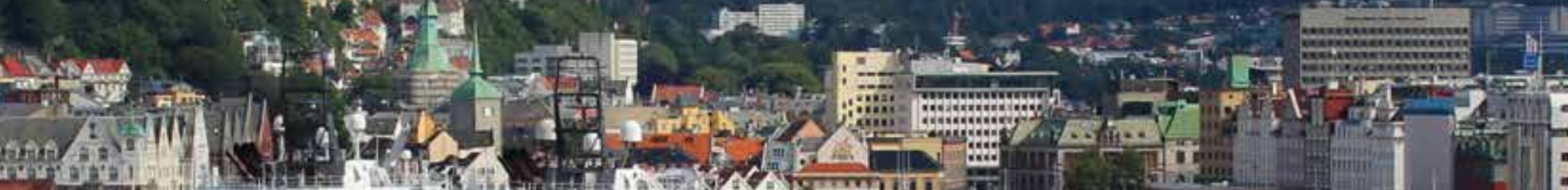

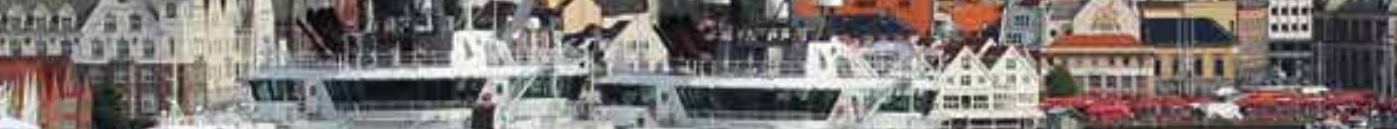

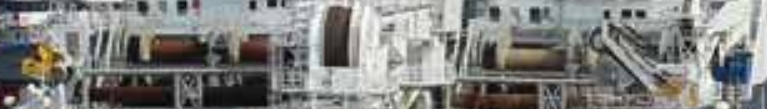

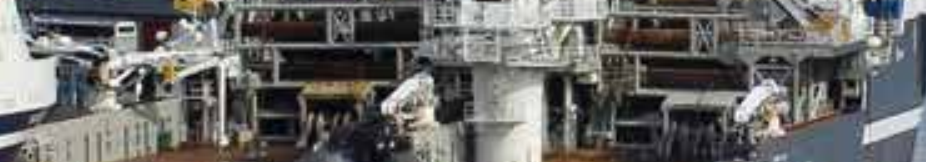

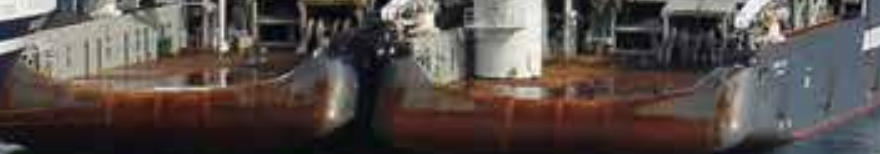

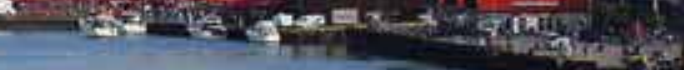

Whet on in in

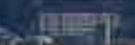

政

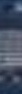




\section{Det förebyggande arbetet}

Samarbetsministrarna har i sin strategi och handlingsplan för nordisk mobilitet 2014-2017 slagit fast att det nordiska gränshinderarbetet även ska syfta till att förebygga att nya gränshinder uppstår.

I sin deklaration om mobilitet i Norden den 29 oktober 2013 fastställde de nordiska statsministrarna att detta ska uppnås bl.a. genom att så långt det är möjligt säkra ett likartat genomförande av EU-rättslig lagstiftning i Norden och att länderna ska samråda när de inför nya lagar och regler för att förhindra att nya gränshinder uppstår.

I samarbete med den nordiska socialförsäkringsgruppen, som består av tjänstemän inom socialförsäkringsområdet i de nordiska länderna, och Nordiska ministerrådets informationstjänst Hallå Norden förbereder Gränshinderrådets sekretariat två seminarier om långa handläggningstider i EU-ärenden om socialförsäkringar som planeras att äga rum under 2018 och 2019. Seminariernas främsta målgrupp är seniorhandläggare som ska få bättre färdigheter i att förstå de andra nordiska ländernas socialförsäkringssystem samt knyta bestående kontakter med varandra.

Sekretariatet kommer i samband med Gränshinderrådets nya mandat att under 2018 se över uppdrag och samarbetsformer kopplade till det förebyggande arbetet. 


\section{Mandat for Grænsehindringsrådet 2018-2021}

\begin{abstract}
Baggrund
Arbejdet med at fjerne grænsehindringer er højt prioriteret $\mathrm{i}$ det nordiske samarbejde som en vigtig men dog afgrænset del af arbejdet med at nå statsministrenes vision om at Norden skal være verdens mest integrerede region. Formålet med arbejdet er således i sidste ende at fremme mobilitet og handel mellem de nordiske lande for borgere og erhvervsliv.
\end{abstract}

Det nordiske samarbejde er et mellemstatsligt samarbejde, hvorfor det er de nationale parlamenter, departementer/ministerier, myndigheder og øvrige aktører, som har ansvaret for at ikke tilsigtede/ uønskede grænsehindringer kan løses.

Grænsehindringsrådet skal arbejde for at fjerne grænsehindringer, som berører borgere og erhvervsliv i Norden. Rådets nationale medlemmers ${ }^{1}$ rolle er at være pådrivere overfor de nationale politiske og administrative systemer. Rådet medlemmer skal kunne henvende sig direkte til en nordisk lands minister såfremt det skønnes, at dette er nødvendigt for at få grænsehindringer løst/afklaret.

Rådet skal identificere, prioritere og komme med bidrag til at fjerne grænsehindringer for borgere og virksomheder i Norden i samarbejde med alle de aktører, der nationalt er afgørende for, at grænsehindringer kan løses, herunder nationale forvaltninger og myndigheder, parlamentarikere, informationstjenester, arbejdsmarkeds parter mv.

Arbejdet i rådet skal knyttes tæt op på det aktuelle formandskab i Ministerrådet, dets prioriteringer og politiske lederskab, ligesom generalsekretæren skal være pådriver i grænsehindringsarbejdet i Ministerrådet.

\section{Medlemmerne af Grænsehindringsrådet}

Sverige, Danmark, Norge, Island, Finland, Færøerne, Grønland og Åland kan udpege hver et medlem til Grænsehindringsrådet. Ved udpegning af medlemmer skal man ud over nationale prioriteter lægge vægt på, at medlemmerne opfylder følgende:
- Har et stærkt og aktuelt netværk i de nationale regeringer, på minister-og/eller embedsmandsniveau

- Har erfaring med arbejde inden for et eller flere af de områder, hvor de fleste grænsehindringer findes (arbejdsmarked, socialpolitik, skat, uddannelse eller næring)

- Har den nødvendige mulighed for at prioritere arbejdet i Grænsehindringsrådet

- Har den nødvendige frihed til at agere i arbejdet med at fjerne grænsehindringer, hvilket betyder, at man har mulighed for ud fra egne vurderinger at beslutte og afholde nationale møder med berørte ministerier og departementsmedarbejdere, når dette kræves, for derigennem at have muligheden for at sikre og prioritere de grænsehindringer, som de anser for væsentlige.

Udover de nationale medlemmer er Nordisk Ministerråds generalsekretær medlem af Grænsehindringsrådet, og Nordisk Råd har også et medlem i rådet.

Ved sammensætningen af rådet tilstræbes en jævn kønsfordeling.

\section{Formandskab for Grænsehindringsrådet}

Formandskabet for Grænsehindringsrådet går på skift og følger formandskabet for Nordisk Ministerråd. Formandskabet leder arbejdet i Grænsehindringsrådet i samarbejde med Nordisk Ministerråds generalsekretær.

Formandskabet for Grænsehindringsrådet skal have en løbende og tæt dialog med sin nationale repræsentant i den Nordiske Samarbejdskomité (NSK) og samarbejdsminister med henblik på at sikre overensstemmelse mellem formandskabslandets prioriteringer generelt og arbejdet i Grænsehindringsrådet. Denne dialog skal også ske før formandskabsåret indledes, således at grænsehindringer inddrages $i$ formandskabsprogrammet for Nordisk Ministerråd. Samtlige nationale medlemmer bør have en løbende og tæt dialog med deres nationale NSK repræsen-

${ }^{1}$ Når der i dette mandat tales om land og nationalt medlem menes Danmark, Finland, Island, Norge, Sverige, Grønland, Åland og Færøerne (og medlemmer fra disse lande). 
tant og samarbejdsminister for at sikre fremdrift i processen med det respektive lands prioriterede grænsehindringer.

Formandskabet for Grænsehindringsrådet skal stille sig til rådighed for en årlig afrapportering om arbejdet i Grænsehindringsrådet til statsministrene, hvis det siddende formandskab for Ministerrådet anser, at der er behov for at løfte arbejdet til statsministerniveau.

Endelig skal formandskabet for Grænsehindringsrådet sikre, at tidligere års prioriteringer også videreføres i arbejdet.

\section{Opgaver}

Det kvantitative mål er at få afklaret 8-12 grænsehindringer om året i Grænsehindringsrådets regi. Afklaret indebærer, at hindringen bliver løst, eller at det afklares, at hindringen ikke kan løses. Denne beslutning rapporteres, og Grænsehindringsrådet arbejder ikke videre med den pågældende grænsehindring.

Kvantitative mål skal komplementeres med kvalitative mål, som fastlægges efter drøftelse i Grænsehindringsrådet og under hensyntagen til borger-og næringsperspektivet samt nationale og regionale forhold, for at sikre at de prioriterede grænsehindringer er af en væsentlig betydning for mobiliteten i Norden.

Der skal løbende følges tæt op på resultaterne af arbejdet og vurderes behov for ændringer, der kan bidrage til, at endnu flere og væsentlige grænsehindringer løses til gavn for borgere og virksomheder i Norden. Der skal desuden løbende følges op på de afklarede grænsehindringer.

Grænsehindringsrådet skal i samarbejde med relevante aktører i landene:

- Identificere og udrede grænsehindringer for borgere og virksomheder i Norden på baggrund af indspil fra blandt andet Hallo Norden og de regionale informationstjenester.

- Forsøge i samarbejde med landene at finde løsninger på grænsehindringer.

- Afgøre hvilke grænsehindringer, som det er væsentligst for rådet at gå videre med i forhold til borgere, virksomheder og landene, og på den baggrund vurdere grænsehindringens betydning og derudfra vurdere det mest hensigtsmæssige niveau for de videre kontakter (MR/EK, nationale ministerier eller på et mere operativt niveau som fx myndigheder arbejdsgrupper, institutioner, brancheorganisationer $\mathrm{mv}$ ).

- Bidrage til at landene ikke skaber nye grænsehindringer i forbindelse med ny national lovgivning og udmøntning af EU/EØS regulering. Dette skal ske i tæt dialog med berørte departementer/ministerier.

- Etablere samarbejde med Solvit nationalt og så vidt muligt videreformidle grænsehindringer, der er ulovlige i henhold til EU-retten, til Solvit. Sager, som afvises hos Solvit, kan håndteres i rådet.

- Samarbejde med regionale informationstjenester, grænsekomitéer og Hallo Norden for at få grænsehindringere identificeret og indrapporteret til NMRS og Grænsehindringsdatabasen. Efterfølgende kvalitetssikres disse af NMRS/Grænsehindringsrådet i samarbejde med berørte departementer. Problemstillinger, som identificeres i den forbindelse som reelle problemer for borgere og virksomheder, men som ikke kvalificerer som grænsehindringer, søges videreformidlet til håndtering $\mathrm{i}$ andre relevante fora.

- Samarbejde med ministerråd og embedsmandskomitéer under Nordisk Ministerråd, nationale forvaltninger og myndigheder.

Grænsehindringsrådet kan desuden

- repræsentere grænsehindringsarbejdet ud ad til: Holde møder med ministre og embedsmænd (MR/ EK) om grænsehindringer, holde oplæg til konferencer $\mathrm{mv}$.

- igangsætte relevante analyser og arrangere løsningsorienterede seminarer o.l., der kan understøtte arbejdet med at fjerne grænsehindringer i Norden.

Rådet mødes ca. 4 gange årligt efter behov, og $\mathrm{i}$ forbindelse med et årligt kickoff-møde, der afholdes i forbindelse med, at en ny formand tiltræder, og hvor fokus er at evaluere og videreudvikle arbejdet.

Der tilstræbes videst mulig informationsudveksling med og transparens i forhold til Nordisk Råds grænsehindringsgruppe. 


\section{Opgaver for de nationale medlemmer af Grænsehindringsrådet}

Respektive medlemmer af Grænsehindringsrådet har ansvar for at sikre forankring af arbejdet med at fjerne grænsehindringer nationalt. De skal således etablere et samarbejde med de aktører nationalt, der er afgørende for, at grænsehindringer kan løses, herunder nationale forvaltninger, arbejdsmarkeds parter, informationstjenester mv.

Det respektive nationale medlem skal have et velegnet redskab til at løse denne opgave. Det skal gøres ved at etablere en national netværksgruppe, hvor man holder jævnlige møder i tilknytning til arbejdet i Grænsehindringsrådet. I grupperne kan dagsordenen for møderne i Grænsehindringsrådet diskuteres og gennemgås, man kan rejse aktuelle grænsehindringer, gøre status på igangværende processer samt orientere om aktuelle aktiviteter.

Netværksgruppen kan bestå af følgende grænseregionale og nationale deltagere:

- Det nationale medlem af Grænsehindringsrådet

- Embedsmænd fra det nationale NSK kontor

- Permanent repræsentation fra de mest berørte ministerier og myndigheder, samt øvrige myndigheder i henhold til mødets dagsorden

- De grænseregionale informationstjenester

- Hallo Norden

- Relevante parlamentarikere fra den nationale delegation til Nordisk Råd

- Arbejdsmarkedets parter når det er relevant i henhold til mødets dagsorden

- Evt. en deltager fra NMRS

- Evt. en deltager fra den nationale ombudsinstitution

Gennem disse grupper kan etableres og udvikles nordiske netværk på forskellige specialområder efter behov.

Udover de nationale netværk, hvor størstedelen af det nationale grænsehindringsarbejde udføres, kan samarbejdsministeren sammen med Grænsehindringsrådets medlem indkalde til møde med berørte ministrer, hvor Grænsehindringsrådets prioriterede grænsehindringer diskuteres.
Hvert år afrapporterer de enkelte medlemmer af Grænsehindringsrådet til den nationale samarbejdsminister om hvilke aktiviteter, man har igangsat nationalt $\mathrm{i}$ arbejdet med at fjerne grænsehindringer.

Grænsehindringsrådets medlem afrapporterer, hvad man har gennemført nationalt i arbejdet med at eliminere grænsehindringer til samarbejdsministeren med Grænsehindringsrådets årsrapport som grundlag. I afrapporteringen præsenterer man også hvilke tiltag man påtænker at lave de følgende år med udeståender og ny prioriterede grænsehindringer.

\section{Generalsekretærens rolle}

Generalsekretæren har som medlem af Grænsehindringsrådet særligt i opdrag

- at føre sager fra arbejdet i Grænsehindringsrådet videre til berørte ministerråd og embedsmandskomitéer under Nordisk Ministerråd

- at bidrage til god koordination og organisering af arbejdet

- at sikre, at der rapporteres fra arbejdet i Grænsehindringsrådet til Nordisk Råds session som en del af samarbejdsministrenes årlige redegørelse for grænsehindringsarbejdet.

Generalsekretæren stiller sekretariatsbistand fra Nordisk Ministerråds sekretariat til rådighed for arbejdet i Grænsehindringsrådet. Sekretariatet koordinerer arbejdet, udarbejder mødemateriale samt står for de praktiske dele af arbejdet i forbindelse med planlægning og gennemførelse af møderne. Sekretariatet har ansvar for Grænsehindringsdatabasen.

Generalsekretæren har ansvaret for udarbejdelse af dagsorden og indstilling til beslutninger, men arbejdet sker i dialog med det aktuelle formandskab for Grænsehindringsrådet.

\section{Landenes rolle}

Som støtte for Grænsehindringsrådets arbejde bistår landene i så vidt muligt omfang med juridisk og faglig ekspertise, hvor det er nødvendigt. Hvert land udpeger i alle relevante ministerier en kontaktperson, ${ }^{2}$ der som indgang til ministeriet kan hjælpe Grænsehindringsrådet med de nødvendige kontakter til brug for

\footnotetext{
${ }^{2}$ Landene beslutter om kontaktpersonen skal være de nationale EK-medlemmer eller en anden.
} 
arbejdet med at identificere, udrede og finde løsninger på grænsehindringer.

Landene har ansvaret for evt. servicering af sit nationale medlem fagligt såvel som praktisk. Medlemmerne af Grænsehindringsrådet har selv ansvar for bookninger og andre logistiske gøremål, som følger af opdraget.

\section{Budget, honorering etc.}

Der afsættes midler i det nordiske budget til Grænsehindringsrådets arbejde, herunder midler til at indhente analyser og udredninger fra eksterne aktører.

Landenes repræsentanter i Grænsehindringsrådet kan afhængig af reglerne i hjemlandet modtage en årlig aflønning/honorar fra det nordiske budget for arbejdet i Grænsehindringsrådet, ${ }^{3}$ mens omkostninger i forbindelse med rejser, møder mv finansieres nationalt af landene.

Mandatperioden er 1. januar 2018 - 31. december 2021. I forbindelse med rapporteringen efter $2019 \mathrm{~g} ø \mathrm{r}$ MR-SAM status over erfaringerne med mandatet.

${ }^{3}$ Hvis de nationale regler ikke tillader aflønning, fx hvis medlemmet er embedsmand, udbetales aflønningen til pågældendes arbejdsgiver som kompensation for den arbejdstid, der anvendes til opgaven som medlem af Grænsehindringsrådet. 


\section{Efterord Gränshinderrådets ordförande 2018}

Under 2018 är Sverige ordförandeland i Nordiska ministerrådet. Ledord för samarbetet under det svenska ordförandeskapet är ett inkluderande, innovativt och tryggt Norden med digitalisering som en röd tråd.

Sedan länge har gränshinderfrågor prioriterats i det nordiska samarbetet. Gränshinderrådet har sedan 2014 verkat för att undanröja gränshinder och underlätta pendlingen för personer som arbetar, studerar, flyttar och företag som driver verksamhet över de nordiska gränserna.

I våras visade en extern utvärdering, gjord av Oxford Research, att Gränshinderrådets arbete fungerat väl under de första tre åren och lett till önskade resultat. De nordiska samarbetsministrarna beslutade därför vid sitt oktobermöte 2017 att rådet skulle få ett förnyat mandat med ökade befogenheter och uppdraget att i tätt samarbete med berörda aktörer bidra till att ännu fler hinder gränshinder blir behandlade varje år.
Även om det fortfarande finns många gränshinder kvar i Norden ses vårt täta, nordiska samarbete över gränserna för att öka mobiliteten och motverka hinder som en förebild av omvärlden. Inom EU har t.ex. EU-kommissionens DG Regio (generaldirektoratet för regionala frågor) haft fokus på EU:s interna gränsregioner och besökte förra året Öresundsregionen. Där träffade de berörda aktörer för att få veta mer om hur man arbetar tillsammans över nationsgränserna. De kommer bl.a. att hålla en workshop i Köpenhamn i januari kring dessa frågor.

Som ordförande i Gränshinderrådet under 2018 är min ambition att vårt arbete ska bidra till att främja ett ännu mer integrerat Norden. De hinder, och den brist på information, som på olika sätt gör det svårare att flytta, pendla, studera eller bedriva näringsverksamhet över gränserna i Norden måste bli färre. Under 2018 kommer Sverige aktivt arbeta för detta i Gränshinderrådet. 



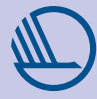

Nordiska ministerrådet

Nordens Hus

Ved Stranden 18

DK-1061 København K www.norden.org

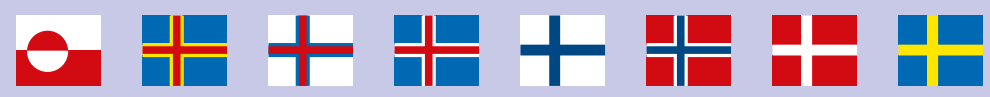
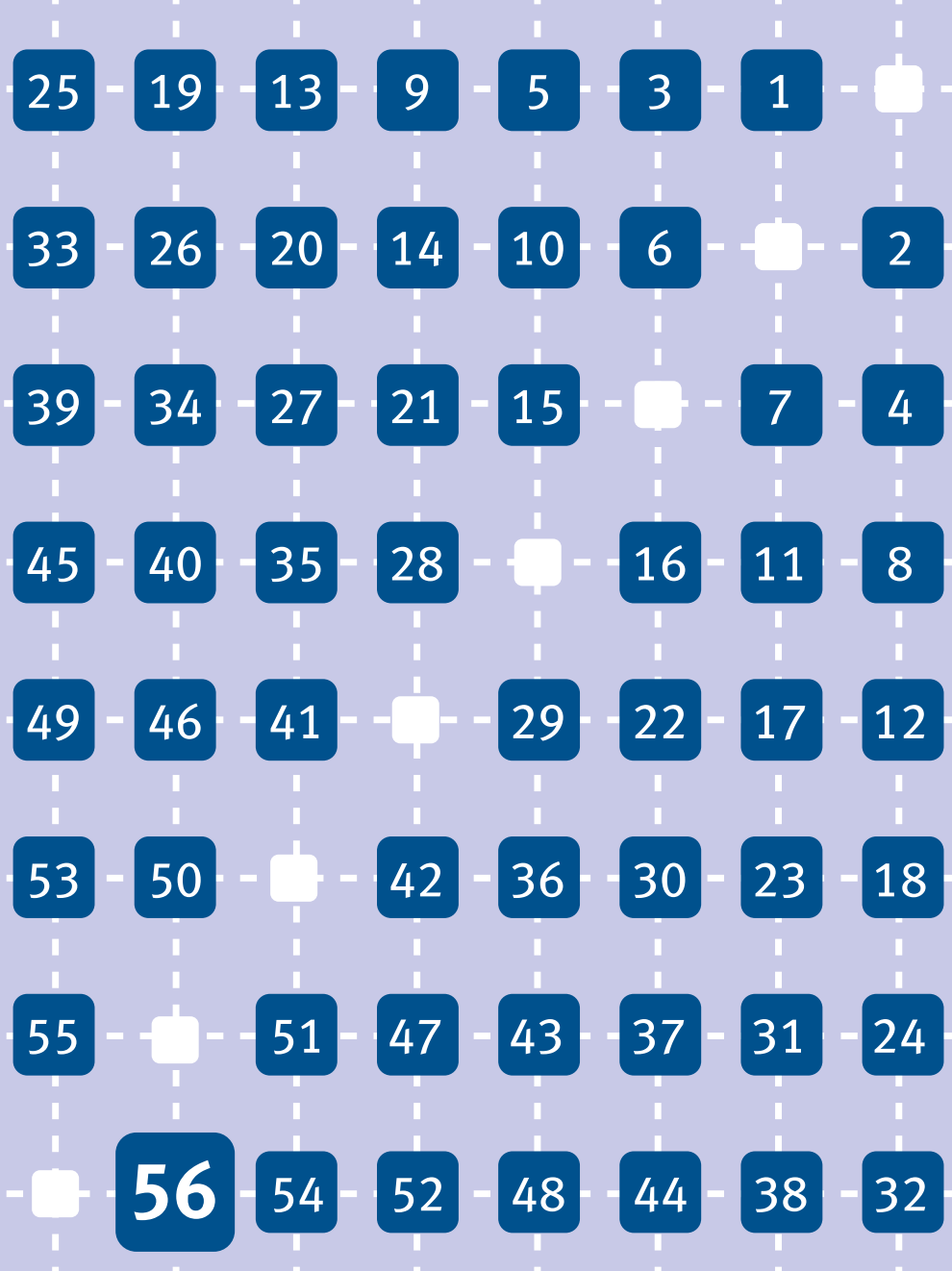